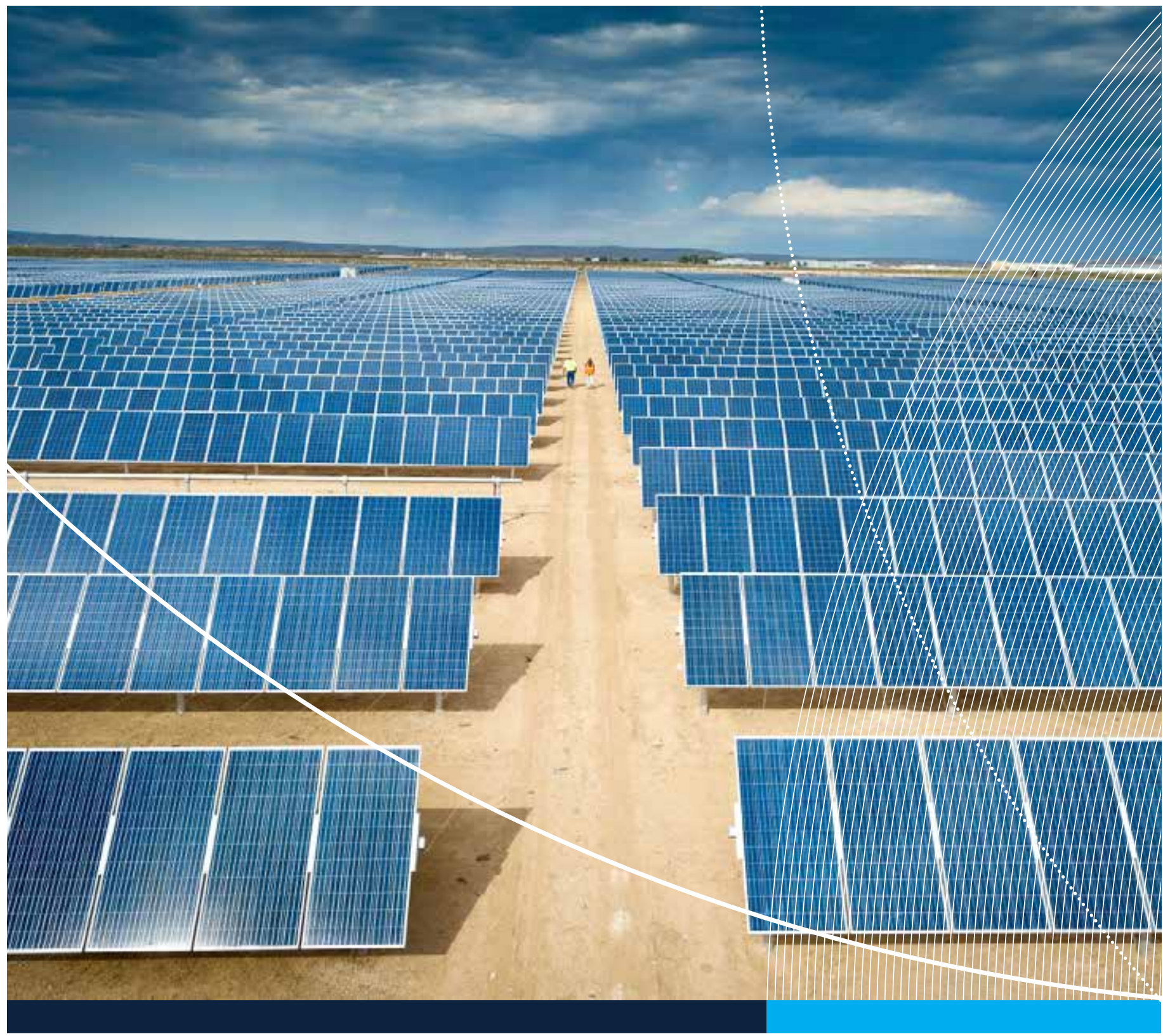

\title{
A Solar Developer's Guide to Pakistan
}

IN PARTNERSHIP WITH:

Australian

Aid

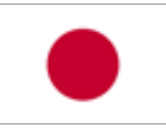

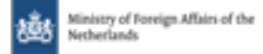





\section{Acknowledgements}

This Guide was developed as part of the IFC Middle East and North Africa (MENA) Renewable Energy Development Support Advisory program, funded by AusAid, Japan, and The Netherlands for activities in Pakistan. The overall goal of this multi-year program is to enhance the scale up and development of renewable and clean energy in MENA by supporting developers and investors in MENA markets, increasing overall market awareness and understanding, and facilitating public-private dialogue.

The Guide was prepared under the overall guidance of Bryanne Tait, IFC's Regional Lead for Energy and Resource Efficiency Advisory, Middle East and North Africa. We acknowledge the significant contributions of Sohail Alam, IFC Energy Specialist and Alice Cowman, Renewable Energy Specialist, who has been commissioned by IFC to carry out the desk research, drafting and interviews.

We would like to thank the Pakistan Alternative Energy Development Board, National Electric Power Regulatory Authority, National Transmission and Distribution Company, the Province of Punjab and the Province of Sindh, who contributed greatly to the research and study for this guide through interviews and provision of information and documents. IFC would also like to express its sincere appreciation to RIAA Barker Gillette, Ernst \& Young, and Eversheds, who contributed to the drafting of the guide. Solar resource maps and GIS expertise were kindly provided by AWS Truepower and colleagues from the World Bank respectively, including support from the Energy Sector Management Assistance Program (ESMAP). Certain mapping data was obtained from OpenStreetMap, and copyright details for this can be found at http://www.openstreetmap.org/copyright. Interviews provided by Power Planners International and reviews by Nizam Energy added value to the final guide.

\section{Contributing Partners}

RIAA Barker Gillette
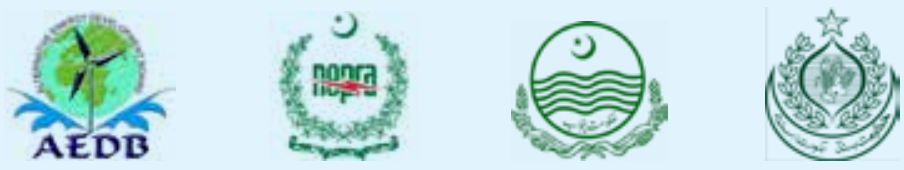


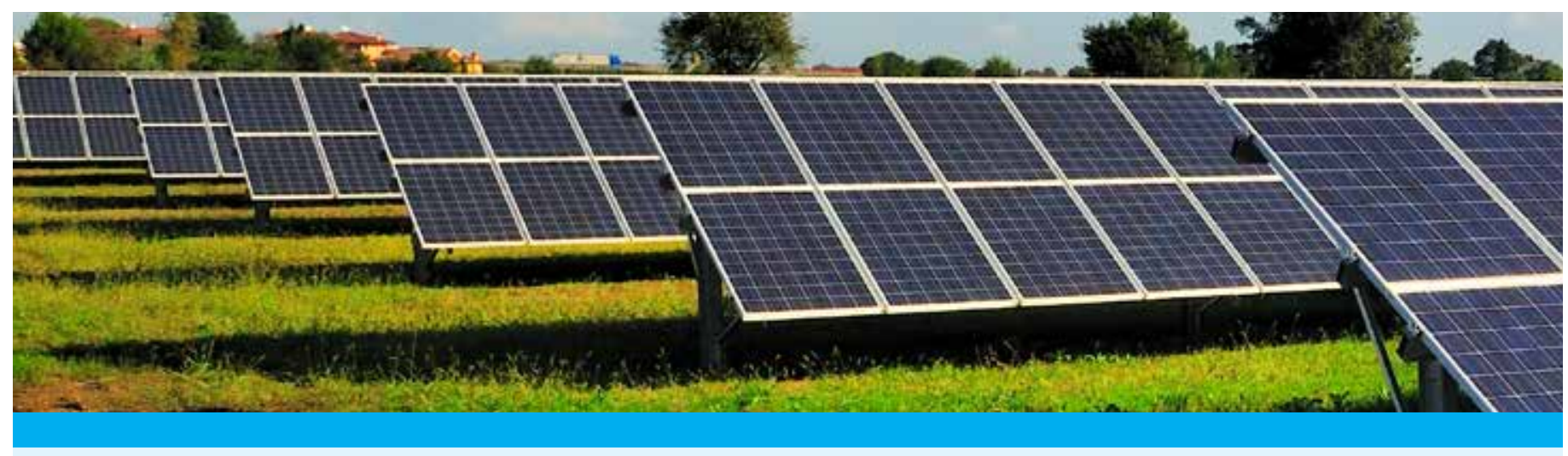

\section{Table of Contents}

$\begin{array}{lr}\text { INTRODUCTION AND OUTLINE } & \text { o9 }\end{array}$

$\begin{array}{lr}\text { 1. COUNTRY PROFILE } & 10\end{array}$

2. SOLAR PV POTENTIAL IN PAKISTAN 12

3. SOLAR SECTOR DEVELOPMENT TO DATE IN PAKISTAN $\quad 15$

4. POWER SECTOR INSTITUTIONS 16

4.1 EXECUTIVE AND REGULATORY AGENCIES 16

4.1.1. NATIONAL ELECTRIC POWER REGULATORY AUTHORITY (NEPRA) 16

4.1.2. THE ALTERNATIVE ENERGY DEVELOPMENT BOARD (AEDB) 16

4.1.3. PROVINCIAL AND AJK AGENCIES 16

4.2. OFF-TAKERS/POWER PURCHASERS 16

4.2.1. CENTRAL POWER PURCHASING AUTHORITY (CPPA) 16

4.2.2. DISTRIBUTION COMPANIES (DISCOS) 17

$\begin{array}{ll}\text { 4.2.3. K-ELECTRIC } & 17\end{array}$

$\begin{array}{ll}\text { 4.3. TRANSMISSION } & 17\end{array}$

$\begin{array}{lr}\text { 5. TARIFF DETERMINATION } & 18\end{array}$

$\begin{array}{ll}\text { 5.1. TARIFF PROCESS OVERVIEW } & 18\end{array}$

5.2. FIT ASSUMPTIONS, ADJUSTMENTS AND INDEXATIONS

$\begin{array}{ll}\text { 5.3. } 2016 \text { TARIFF } & 22\end{array}$

6. DEVELOPMENT PROCESS UNDER FIT. 24

$\begin{array}{ll}\text { 6.1. STAGE 1: LETTER OF INTENT } & 28\end{array}$

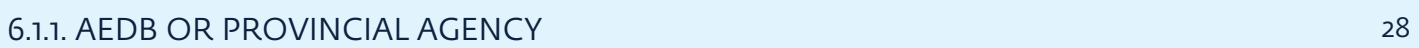

$\begin{array}{ll}\text { 6.1.2. IDENTIFICATION OF LAND } & 30\end{array}$

6.1.3. THE AEDB LOI APPLICATION PROCESS 


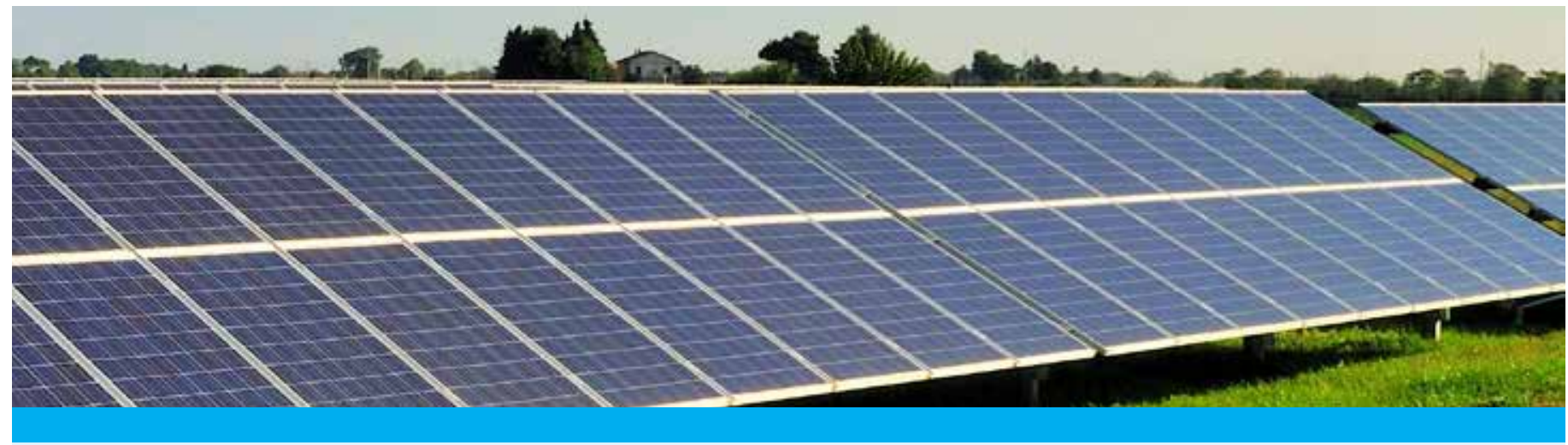

6.2. STAGE 2: LOI TO LOS

6.2.1. LAND ACQUISITION

6.2.2. FEASIBILITY AND GRID INTERCONNECTION 38

6.2.3. NEPRA FIT APPLICATION AND GENERATION LICENSE APPLICATION 39

6.2.4. ENVIRONMENTAL ASSESSMENT

6.2.5. LETTER OF SUPPORT AND PERFORMANCE GUARANTEE 42

6.3. STAGE 3: LOS TO FINANCIAL CLOSE

6.3.1. ENERGY PURCHASE AGREEMENT

6.3.2. IMPLEMENTATION AGREEMENT (IA) 46

$\begin{array}{ll}\text { 6.3.3. GRID INTERCONNECTION } & 48\end{array}$

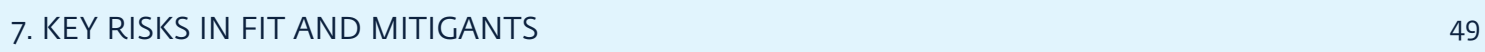

$\begin{array}{ll}\text { 7.1. SECURITY RISKS } & 49\end{array}$

$\begin{array}{ll}\text { 7.2. POLITICAL RISKS } & 49\end{array}$

7.3. CURRENCY PROJECTION AND CURRENCY CONVERTIBILITY 49

7.4. ACTIVE RISK MITIGATING INSTITUTIONS 50

7.4.1. MULTILATERAL INVESTMENT GUARANTEE AGENCY (MIGA) 50

$\begin{array}{ll}\text { 7.4.2. WORLD BANK (IBRD/IDA) } & 51\end{array}$

7.4.3. ASIAN DEVELOPMENT BANK (ADB)

7.4.4. OTHER FINANCIAL INSTITUTIONS

8. FISCAL REGIME AND TAXATION ON RENEWABLES

8.1. INCOME TAX

8.2. WITHHOLDING TAX

8.3. PROVINCIAL TAXES

8.4. CUSTOM AND IMPORT DUTIES

8.5. SALES TAX/VAT/TURNOVER TAX

8.6. ZAKAT (ISLAMIC TAX)

$\begin{array}{ll}\text { 8.7. OTHER INCENTIVES } & 55\end{array}$ 


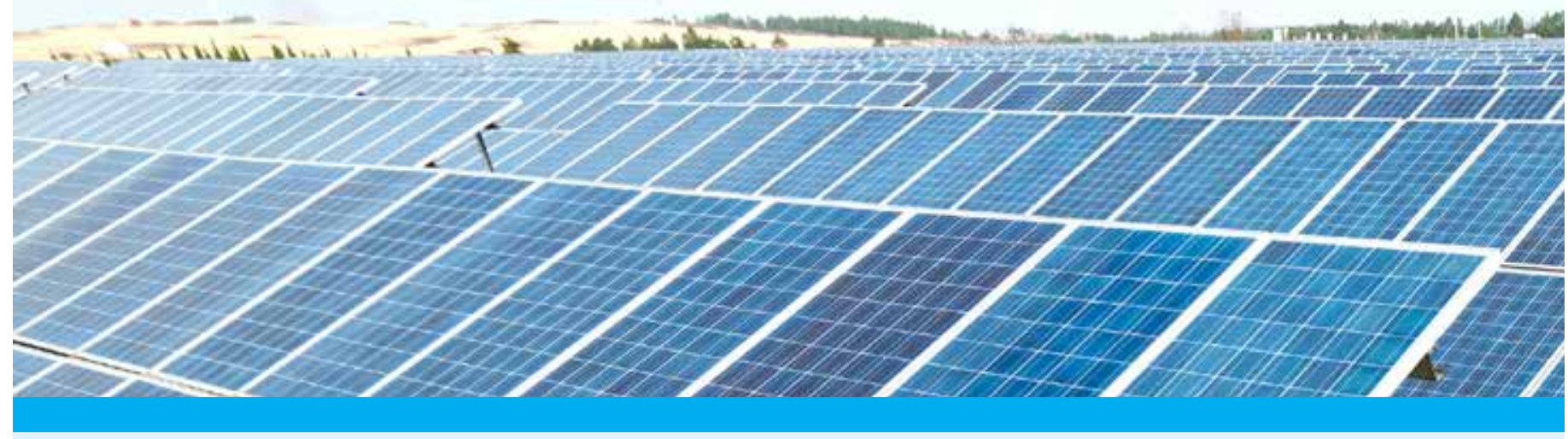

9. CHALLENGES AND RECOMMENDATIONS 56

9.1. POLICY UNCERTAINTY 56

9.2. LAND IDENTIFICATION 56

9.3. TRANSMISSION ISSUES

$\begin{array}{lr}\text { ANNEX } 1 & 58\end{array}$

$\begin{array}{lr}\text { ANNEX } 2 & 60\end{array}$

$\begin{array}{lr}\text { ANNEX } 3 & 62\end{array}$

$\begin{array}{lr}\text { ANNEX } 4 & 64\end{array}$

$\begin{array}{ll}\text { ANNEX } 5 & 69\end{array}$

$\begin{array}{lr}\text { ANNEX } 6 & 71\end{array}$

$\begin{array}{lr}\text { ANNEX } 7 & 73\end{array}$

$\begin{array}{lr}\text { ANNEX } 8 & 79\end{array}$ 
This Guide provides background for investors* who are implementing or intending to implement solar generating plants in Pakistan. The Guide includes an overview of how a solar project could be developed in Pakistan and the legal and regulatory support mechanisms for that project. It also describes legal, regulatory and other issues concerning the preparation, agreement, approval and implementation of projects up to financial close.

"In this Guide the general term "Investor" is used to mean "Contractor" or "Developer", i.e. persons who intend to implement or who are already implementing a project to construct a solar plant in Pakistan.

\section{Disclaimer}

The International Finance Corporation (IFC), a member of the World Bank Group, creates opportunity for people to escape poverty and improve their lives. We foster sustainable economic growth in developing countries by supporting private sector development, mobilizing private capital, and providing advisory and risk mitigation services to businesses and governments.

This Guide was commissioned by IFC through its Middle East and North Africa Renewable Energy Program. The conclusions and judgments contained in this report should not be attributed to, and do not necessarily represent the views of, IFC or its Board of Directors or the World Bank or its Executive Directors, or the countries they represent. IFC and the World Bank do not guarantee the accuracy of the accuracy of the data in this publication and accept no responsibility for any consequences of their use.

The maps provided in this Guide are produced with the best information available to IFC, the World Bank and AWS Truepower. Developers should not base commercial decisions on un-validated mapping outputs. The power transmission maps for Pakistan have been obtained from OpenStreetMap (OSM), an open data resource, and in most cases are based on visual identification of transmission lines. As a result, the mapping data is not complete, mainly as a result of poor quality satellite imagery in certain areas of the country, especially for lower voltage transmission lines. The information presented is therefore not a complete or accurate representation and should therefore be used with care.

The material in this work is protected by copyright. Copying and/or transmitting portions or all of this work may be a violation of applicable law. The International Finance Corporation encourages dissemination of its work and hereby grants permission to users of this work to copy portions for their personal, noncommercial use, without any right to resell, redistribute, or create derivative works there from. Any other copying or use of this work requires the express written permission of the International Finance Corporation. 


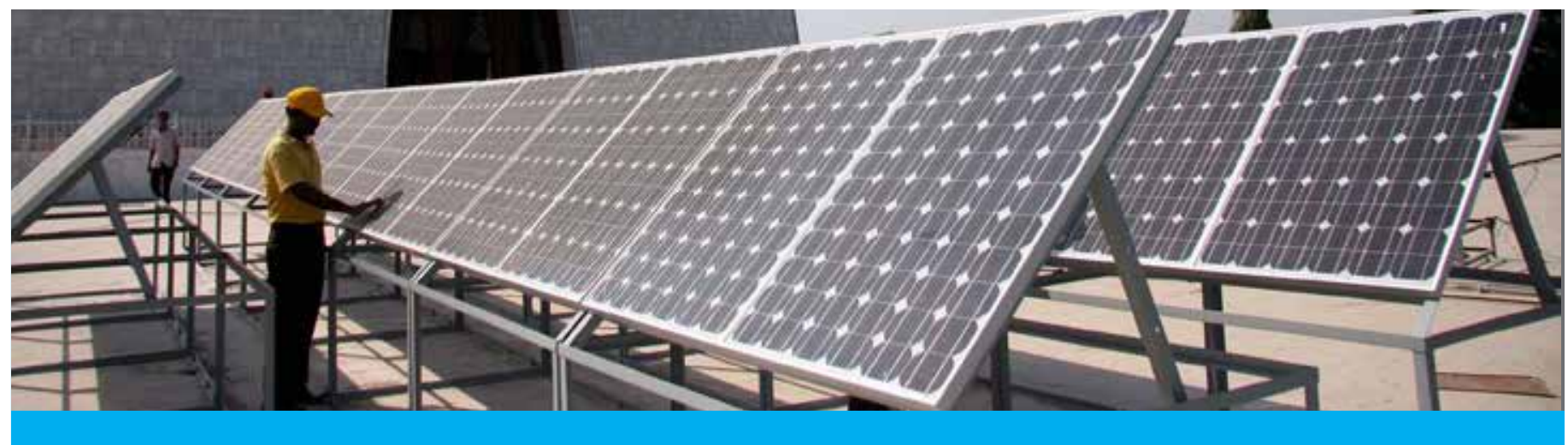

\section{LIST OF KEY ABBREVIATIONS}

\begin{tabular}{|c|c|c|c|}
\hline AEDB & Alternative Energy Development Board & LIBOR & London Interbank Offered Rate \\
\hline AJK & Azad Jammu and Kashmir & LOI & Letter of Intent \\
\hline & (Independent territory of Kashmir & LOS & Letter of Support \\
\hline & Region but part of Pakistan) & MIGA & Multilateral Investment Guarantee \\
\hline $\mathrm{BOO}$ & Build, Own, and Operate & & Agency \\
\hline ВООТ & Build, Own, Operate and Transfer & $M 2$ & Square meter \\
\hline CAPEX & Capital expenditure & MW & MegaWatt \\
\hline CDM & Clean Development Mechanism & MWh & MegaWattHour \\
\hline COD & Commercial Operations Date & NEPRA & National Electric Power Regulatory \\
\hline CPPA & Central Power Purchase Agency & & Authority \\
\hline DISCO & Distribution Company & NTDC & National Transmission and Dispatch \\
\hline EIA & Environmental Impact Assessment & & Company \\
\hline EPA & Energy Purchase Agreement & O\&M & Operations and Maintenance \\
\hline EPC & Engineering, Procurement, & PKR & Pakistani Rupee \\
\hline & Construction & PPA & Power Purchase Agreement \\
\hline FIT & $\begin{array}{l}\text { Feed in Tariff (interchangeably used for } \\
\text { NEPRA's Upfront Tariff) }\end{array}$ & $\begin{array}{l}\text { PPIB } \\
\text { PV }\end{array}$ & $\begin{array}{l}\text { Private Power and Infrastructure Board } \\
\text { Photovoltic }\end{array}$ \\
\hline GOP & $\begin{array}{l}\text { Government of the Islamic Republic of } \\
\text { Pakistan }\end{array}$ & RE & Renewable Energy \\
\hline GWh/yr & GigaWattHour per year & $\begin{array}{l}\text { RFP } \\
\text { ROE }\end{array}$ & $\begin{array}{l}\text { Request for Proposals } \\
\text { Return on Equity }\end{array}$ \\
\hline IA & Implementation Agreement & ROEDC & Return on Equity During Construction \\
\hline IDC & Interest During Construction & OPEX & Operational Expenditure \\
\hline IEE & Initial Environmental Examination & USD or & USA Dollar or USA Cent \\
\hline IPP & Independent Power Producer & US\$ or & \\
\hline IRR & Internal Rate of Return & US Cent & \\
\hline KIBOR & Karachi Interbank Offered Rate & WAPDA & Water and Power Development \\
\hline kV & Kilovolt & & Authority \\
\hline kWh & Kilowatt-hour & WPI & Wholesale Price Index \\
\hline
\end{tabular}




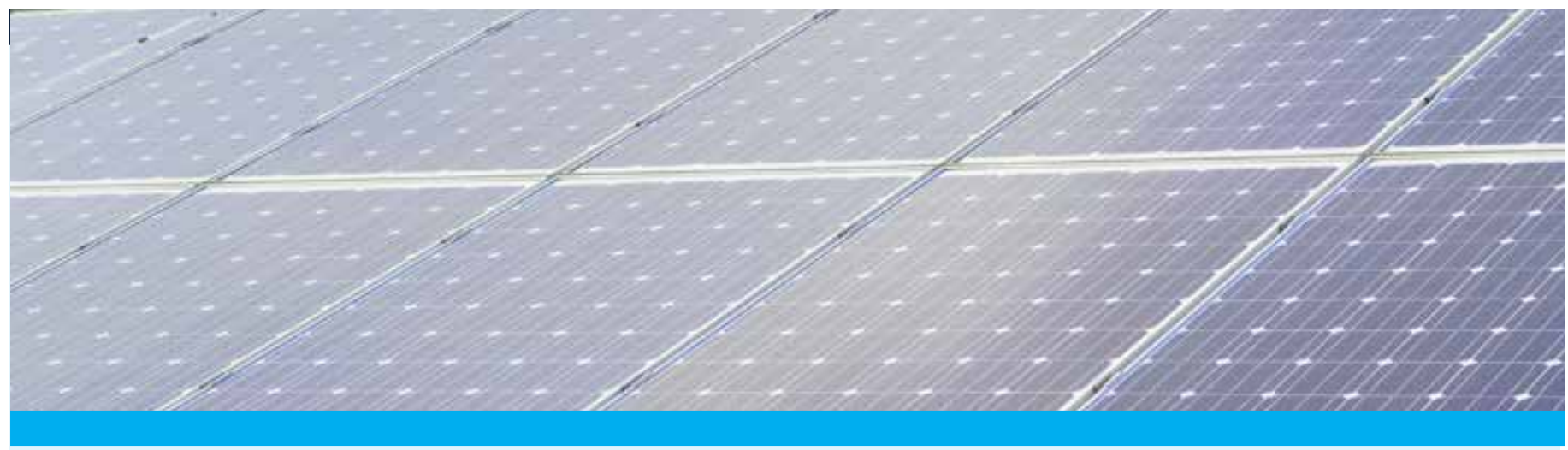

\section{Introduction and Outline}

This document is intended as a guide for international developers and solar investors who are considering investing in Pakistan. The document is laid out as follows:

- Sections 1 to 3 give an overview of Pakistan and its electricity market, the solar potential and progress in the solar market to date.

These sections indicate that Pakistan has tremendous solar energy potential based on irradiance figures throughout the country. Additionally, it has a long history of IPPs and bankable project documents and an improving fiscal situation which is attractive for investors. Solar project development has been slow but it is hoped will gain momentum as recent determinations of solar tariffs have attracted interest from local and international developers.

- Sections 4 to 7 set out the process for developing a solar project in Pakistan and the main institutions both provincial and federal that will be involved in the process.

These sections set out the main policy documents for renewables and describe the three stages for development of a project of a solar project in Pakistan. In summary these are as follows:

- Stage 1: Letter of Intent

- Stage 2: Letter of Intent to Letter of Support

- Stage 3: Letter of Support to Financial Close

- Section 8 sets out some key tax considerations for developers.

- Section 9 concludes with some of the remaining challenges in the solar market in Pakistan currently and some recommendations for developers. The three main considerations for international project developers are:

- Timeline and Policy Uncertainty

- Land Identification

- Transmission and Distribution 


\section{Country Profile}

Pakistan is a federal parliamentary republic. It has four provinces (Khyber Pakhtunkhwa, Balochistan, Punjab, and Sindh), one capital territory (Islamabad Capital Territory), two autonomous and disputed territories (Azad Jammu \& Kashmir and Gilgit Balistan) and the Federally Administered Tribal Areas (FATA). It is the sixth most populous country in the world with a rapidly growing population of over 190 million.

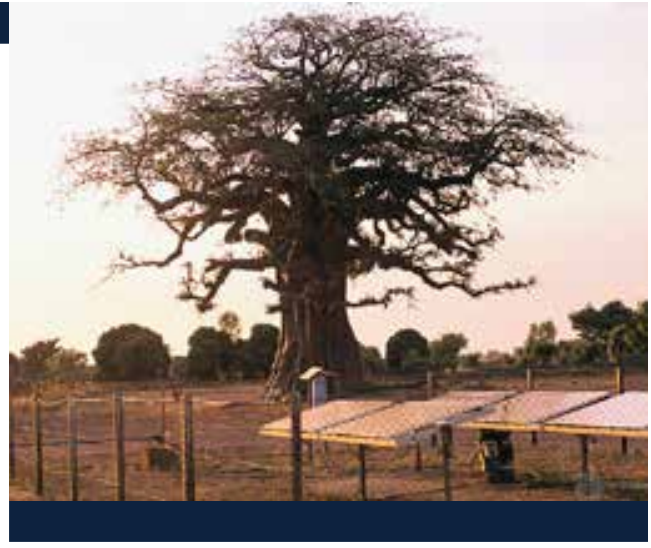

\section{FIGURE 1: PAKISTAN POPULATION DENSITY}

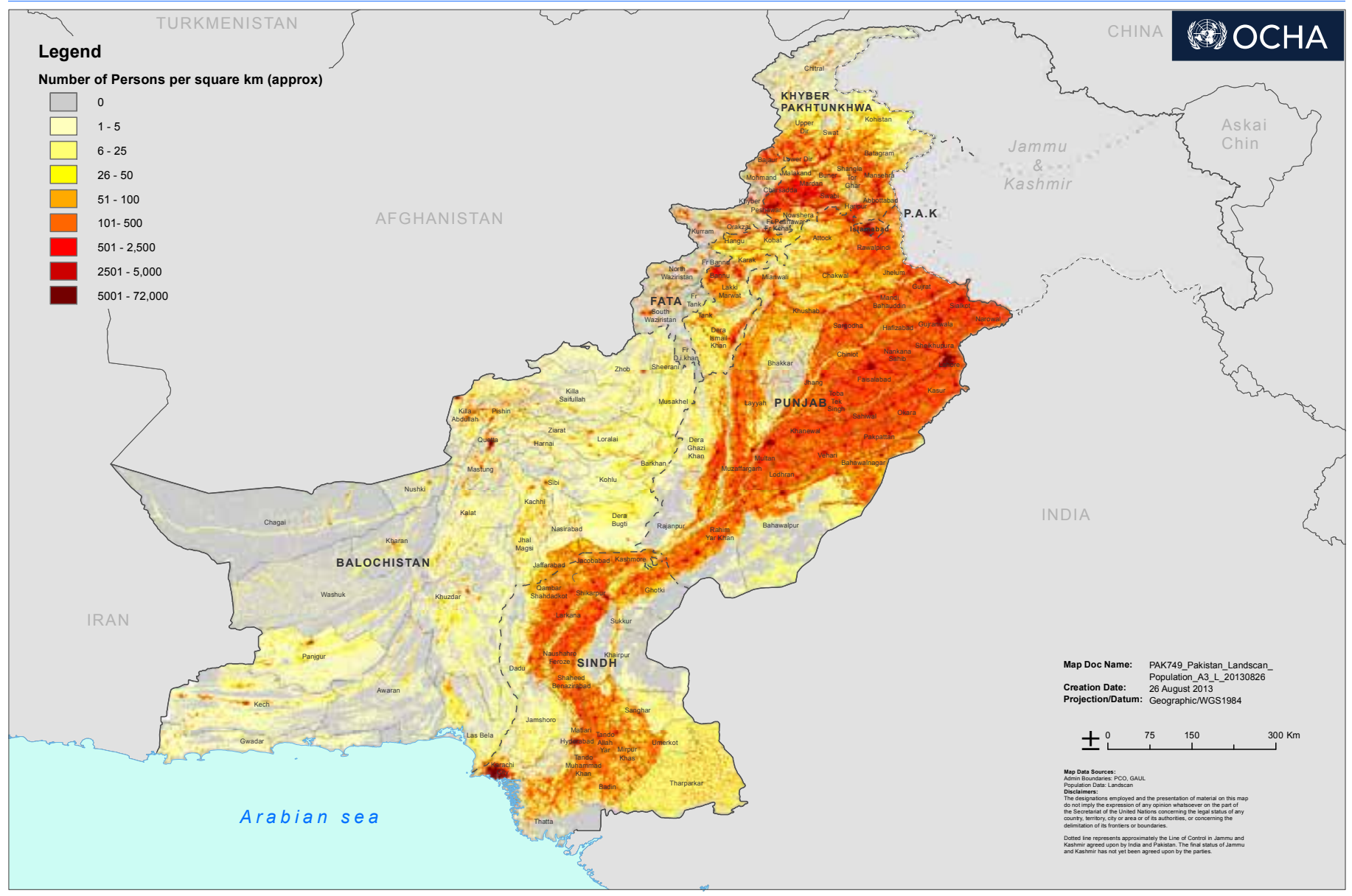

Recent economic developments in Pakistan have largely been positive. In 2015, inflation declined to $4.5 \%$ and GDP growth was $4.2 \%$, up from $4 \%$ in 2014. Growth is expected to continue on an upward trajectory to reach $4.5 \%$ in 2016 and 5.2\% from 2018 onwards. Country risk perception has improved dramatically and the Emerging Markets Bond Index Plus risk spread for Pakistan declined from 1011bps in March 2013, to 461 bps in April 2015. Additionally, Pakistan's S\&P credit rating changed from stable to positive in May 2015 and is currently rated at B-. See Annex 2 for more fiscal information on Pakistan.

Pakistan's energy sector has also undergone a number of structural reforms in the last two decades. In 1998, in an effort to promote increased private sector participation in the market, the Pakistan Electric Power Company was formed to unbundle the Water and Power Development Authority (WAPDA). Prior to unbundling, WAPDA together with the Karachi Electricity Supply Company (KESC - covering only the Karachi area) generated, transmitted and distributed all of the power in the country. In 2007, WAPDA's power function was unbundled into 10 public sector Distribution Companies, 4 Generation Companies and the National Transmission \& Distribution Company (NTDC). Following 
unbundling, WAPA's remaining mandate is development of water and hydropower services in an efficient manner. ${ }^{1}$ KESC was privatized in 2005 and is now known as K-Electric.

For the last decade or so, Pakistan has been facing a severe energy crisis. With installed generation capacity of about 23,600 MW, the country is facing a power shortage of approximately 3,000 MW to 6,000 MW during peak hours (see Figure 2). The crisis worsens during summer months, leading to prolonged load shedding of 8 to 18 hours that varies significantly between urban and rural areas. $37 \%$ of Pakistan's fuel mix is based on fuel oil which means the cost of generation is expensive and highly dependent on oil price changes leading to cost vulnerability. Renewables (other than large hydro), which could lessen this cost vulnerability, contribute less than $1 \%$ of the current renewable energy mix.

For international investors, Pakistan has had a long history of successful completion of IPPs over 20 years. There are 36 IPPs with an installed capacity of 9GW in operation, and an additional 18 IPPs with an installed capacity of 5GW are under construction. There are clear and consistent policies and regulations for IPP development and a strong and independent regulator. There are fiscal incentives, standardized government support documents and long-term offtake contracts on tariffs based on a cost-plus approach and feed-in-tariffs (FITs) with indexations. The contractual framework has been stress tested over the last 20 years by events and situations including the foreign exchange crisis in 1998, periods of political instability, contract renegotiations, persistent circular debt issues at the federal level, significant increases in oil prices and recent sector liquidity issues. Within the renewables space, IPPs have reached financial close in both hydro and wind and gas. International investors such as Engie, GE Capital, Oman Oil, AES Corporation, DEG Germany and International Power UK have already successfully invested in IPPs in Pakistan financed by the IFC, Asian Development Bank, and OPIC, among others.

\section{FIGURE 2: PAKISTAN ELECTRICITY SUPPLY GAP}

\section{Electricity Demand - Supply Gap in Pakistan}

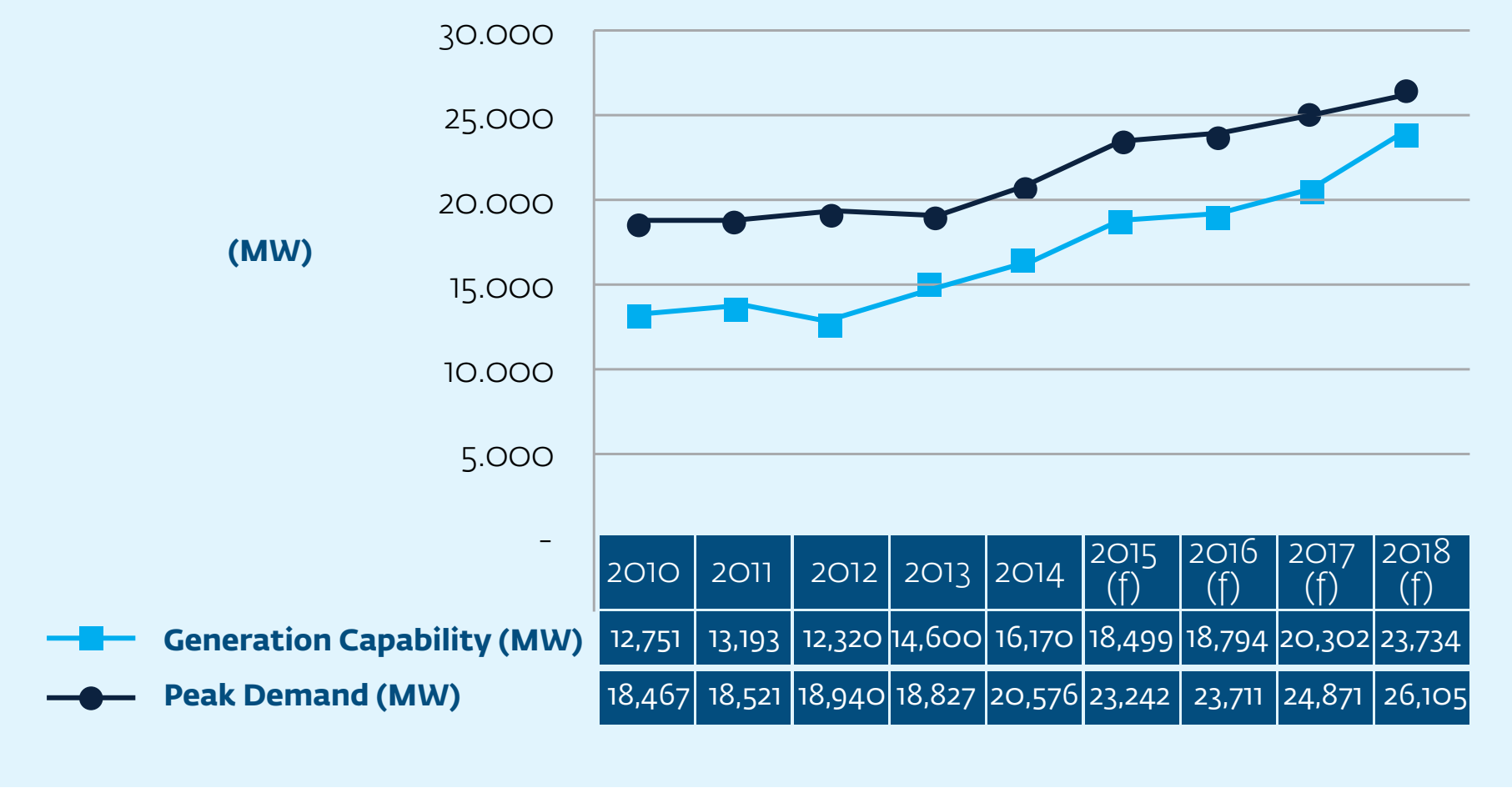




\section{Solar PV Potential in Pakistan}

Pakistan has tremendous potential to meet its power demand needs from renewable energy sources and, in particular, solar.

Solar irradiance levels in parts of Pakistan, particularly in the southwest, are on par with the best in the world with global horizontal irradiance (GHI) values over $1500 \mathrm{kWh} / \mathrm{m}^{2}$ in over $90 \%$ of the country's land area ${ }^{2}$. The annual mean value of GHI for whole Pakistan, based on preliminary

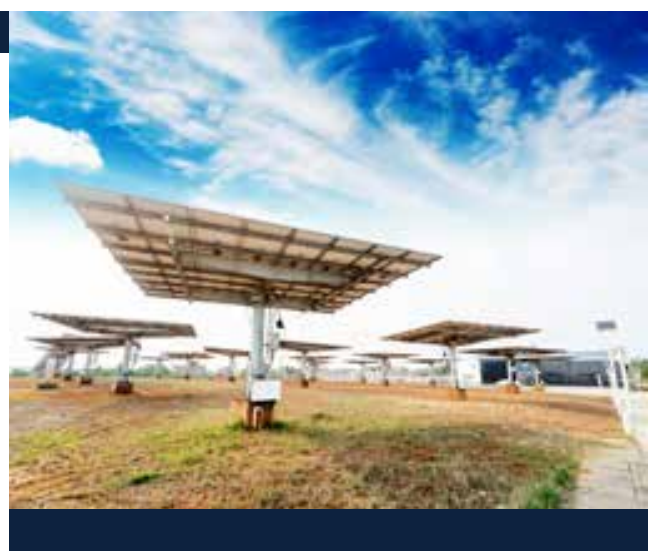
analysis by The World Bank, is $2071 \mathrm{kWh} / \mathrm{m}^{2}$.

The mean values for the individual provinces are listed in Figure 3. The highest values of GHI can be found in Sindh, Balochistan and Punjab provinces, while lowest sums have been estimated for the Northern Regions (including Azad Kashmir) and Khyber Pakhtunkhwa.

\section{FIGURE 3: ANNUAL SUMS OF GHI (2000-2012) FOR PAKISTAN AND PROVINCES BASED ON SATELLITE ESTIMATES}

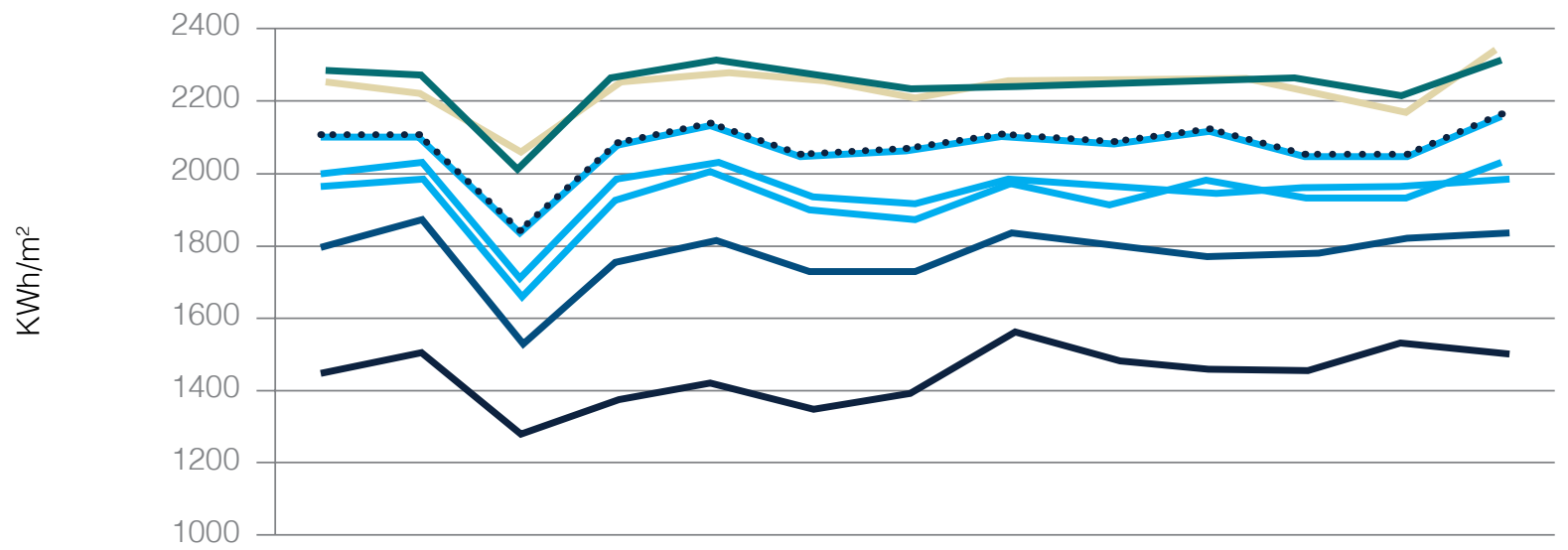

\begin{tabular}{|c|c|c|c|c|c|c|c|c|c|c|c|c|c|c|}
\hline Pakistan & …............. & 2000 & 2001 & 2002 & 2003 & 2004 & 2005 & 2006 & 2007 & 2008 & 2009 & 2010 & 2011 & 2012 \\
\hline Regions & & 2104 & 2100 & 1859 & 2073 & 2111 & 2059 & 2050 & 2103 & 2088 & 2090 & 2075 & 2066 & 2149 \\
\hline Sind & & 1447 & 1506 & 1273 & 1382 & 1415 & 1355 & 1404 & 1545 & 1487 & 1455 & 1454 & 1523 & 1504 \\
\hline & & 2254 & 2215 & 2049 & 2245 & 2273 & 2259 & 2215 & 2260 & 2244 & 2256 & 2225 & 2194 & 2333 \\
\hline Balochistan & & 2284 & 2260 & 2030 & 2254 & 2293 & 2247 & 2227 & 2254 & 2256 & 2252 & 2256 & 2227 & 2319 \\
\hline Punjab & & 2112 & 2104 & 1843 & 2084 & 2123 & 2055 & 2061 & 2099 & 2086 & 2113 & 2061 & 2049 & 2156 \\
\hline Islamabad & & 1966 & 1997 & 1654 & 1931 & 2006 & 1897 & 1866 & 1964 & 1920 & 1966 & 1942 & 1944 & 2025 \\
\hline Fata & & 1996 & 2026 & 1713 & 1980 & 2020 & 1931 & 1918 & 1970 & 1961 & 1954 & 1965 & 1960 & 1997 \\
\hline Nwofn & & 1807 & 1869 & 1530 & 1758 & 1804 & 1728 & 1728 & 1837 & 1801 & 1778 & 1784 & 1819 & 1836 \\
\hline
\end{tabular}

A comprehensive resource assessment and mapping project covering biomass, solar and wind is currently ongoing, with a final Solar Atlas expected in early 2017. The project is being implemented by The World Bank in cooperation with the Alternative Energy Development Board (AEDB), with funding from the Energy Sector Management Assistance Program (ESMAP) and the Asia Sustainable and Alternative Energy Program (ASTAE). Preliminary outputs, including the Solar Modeling Report from which the resource data above was obtained, can be found on the ESMAP website ${ }^{3}$. The solar mapping component includes up to two years of high quality, ground-based solar measurements taken from nine sites across Pakistan (see Figure 4 for details of site locations). The measurement data is being published on The World Bank's Energy \& Extractives Open Data Platform ${ }^{4}$, and can be freely downloaded.

\footnotetext{
2 World Bank Group (2015). Solar Modeling Report. Available at: http://documents.worldbank.org/curated/en/2015/03/24365411/solar-resource-mapping-pakistan-solar-modeling-report 3 Available here: http://esmap.org/re_mapping_pakistan 
FIGURE 4: ESMAP SOLAR MEASUREMENT STATIONS

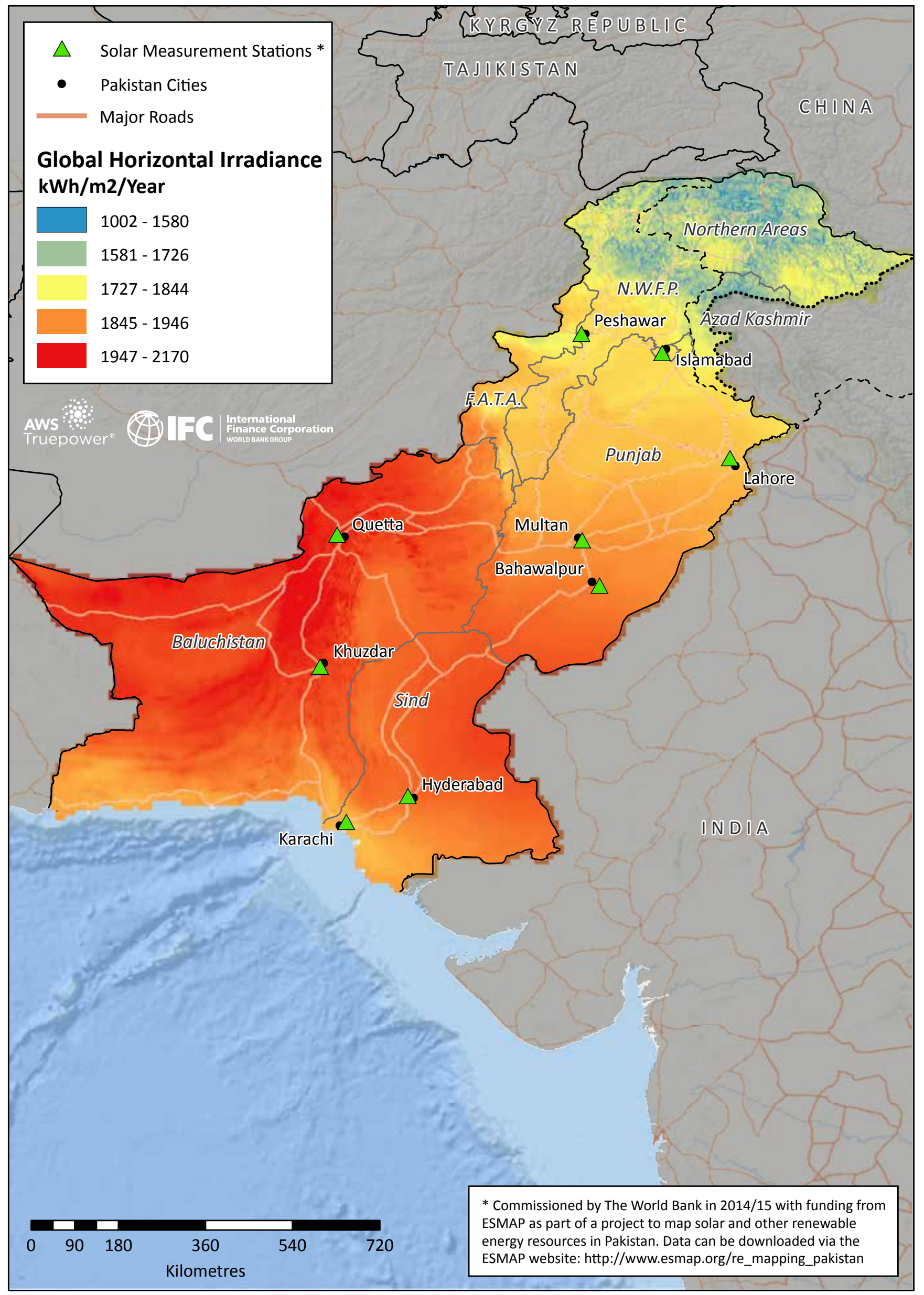




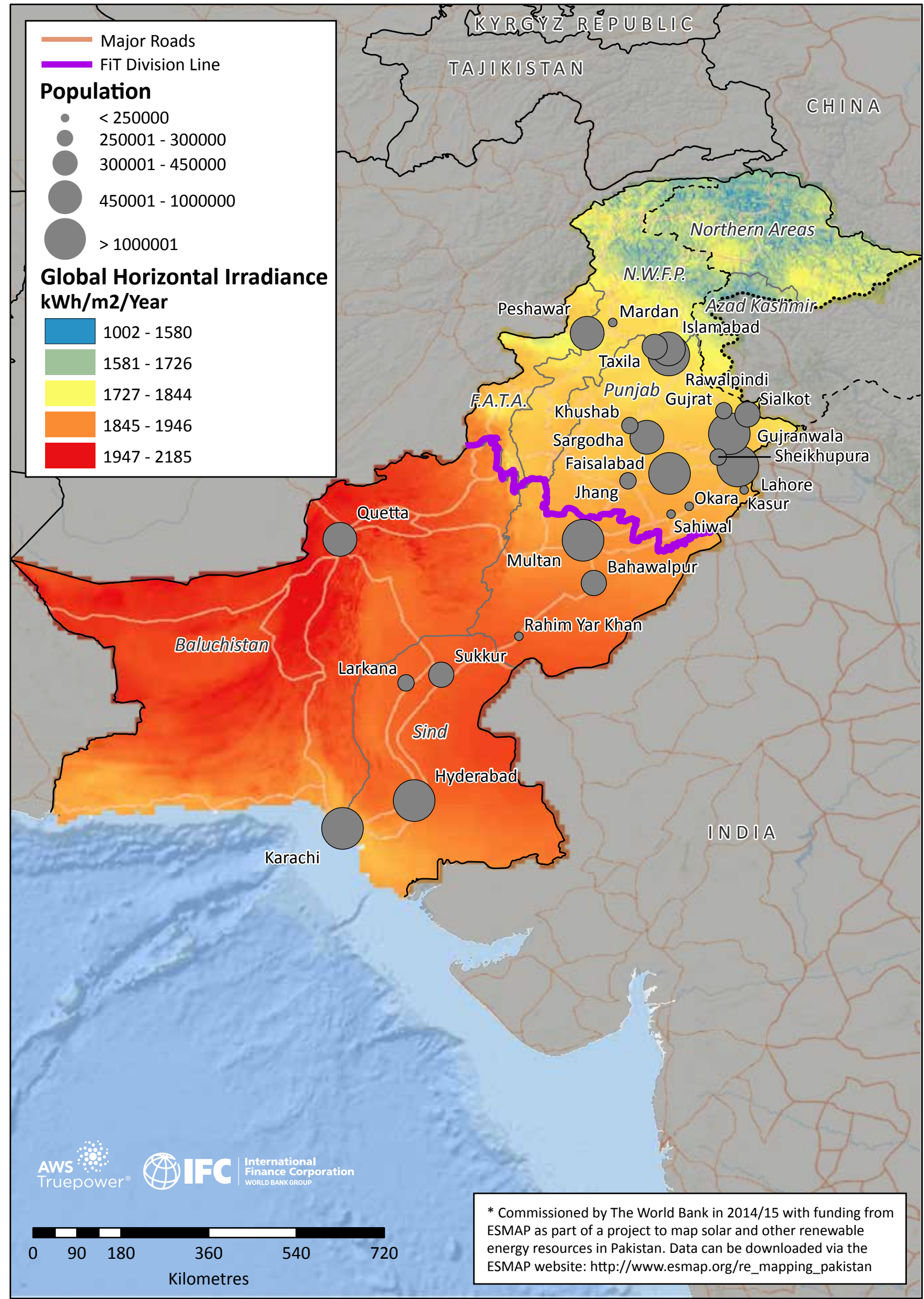




\section{Solar Sector Development to Date in Pakistan}

The Government of Pakistan's (GOP) first steps towards firm support of renewables in its energy mix came in 2006 when it released its Policy for Development of Renewable Energy Generation (the 2006 RE Policy) ${ }^{6}$. The 2006 RE Policy dealt with wind, solar and small hydro ( $<50 \mathrm{MW})$, and set out an initial plan for development of renewables within the country. However, since 2006, progress has been slow and it is only in the last five years that investor interest has gained momentum, particularly in the wind and hydro sector and more recently in solar. The 2006 RE Policy was developed as a short-term policy with a view to developing a medium- and long-term policy as the market developed. However, the 2006 RE Policy remains today the only policy that has been implemented and is currently applicable.

To date, the only grid connected utility scale solar project in Pakistan to reach its Commercial Operation Date (COD) is a publically-sponsored $100 \mathrm{MW}$ project commissioned by the Government of Punjab in May 2015 $5^{7}$. A surge of investor interest since 2014 and recent tariff determinations by the National Electric Power Regulatory Authority (NEPRA) mean that more projects are expected shortly. The Alternative Energy Development Board (AEDB) reports that 35 projects with a capacity of $1111.4 \mathrm{MW}$ are under development within the framework of the AEDB policies and procedures. ${ }^{8}$ FITs (or upfront tariffs as they are known in Pakistan) have been approved for 10 developers, and of those, three projects of 100 MW each have signed a power purchase agreement with the public off-taker. The FITs for a 25-year Solar PPA granted by NEPRA in 2016 are set out in Table 1 below (the 2016 Tariff). Developers must apply for this FIT by 30th June 2016. Further detail on the process by developers/investors to apply for this FIT is found in Section 6, and the basis upon which the tariffs are determined are set out in Section 5 below.

\section{TABLE 1: 2016 SOLAR UPFRONT TARIFF/FIT DETERMINATION BY NEPRA}

\begin{tabular}{|l|l|l|l|}
\hline Category & $>1 \leq 20 \mathrm{MW}$ & $>20 \leq 50 \mathrm{MW}$ & $>50 \leq 100 \mathrm{MW}$ \\
\hline Sorthern Pakistan - Levelized Tariff (US Cents/kWh) & 11.5327 & 11.4460 & 11.3560 \\
\hline
\end{tabular}

In the distributed solar space, the market has also been developing. With the rising costs of electricity in Pakistan and unreliable grid supply, more industries and commercial organizations are turning to captive solar solutions. There has been a strong surge in domestic installation of rooftop PV panels in large cities of the country. Pakistan's private sector imported $350 \mathrm{MW}$ of solar panels in $2013^{9}$.

For projects under $1 \mathrm{MW}$, net metering regulations ${ }^{10}$ came into effect on 1 September, 2015. This sector is expected to see significant growth in the coming years, and Pakistan is targeting at least 1 million customers and adding approximately $3000 \mathrm{MW}$ of solar power through net metering. ${ }^{11}$

Under the 2006 RE Policy, solar power project developers may also enter into direct bilateral sales contracts with end-use customers to sell part of the power generated by them to their direct customers and the rest to the utility company for general distribution. For direct sales, they are required to pay wheeling charges for the use of the transmission/and or distribution grid network used to transport the power from the plant to the purchaser. Until now, there are no known solar projects in Pakistan that are selling power on a bilateral basis.

6 Found at: http://www.aedb.org/Documents/Policy/REpolicy.pdf

7 This project was developed by Quaid E-Azam Solar (Pvt) Ltd at Quaid E- Azam Solar Park

8 AEDB presentation at London 2015 conference

9 Dawn News: Solar energy to be brought into national power grid (7th January 2015)

10 National Electric Power Regulatory Authority (Alternative and Renewable Energy) Distributed Generation and Net -Metering Regulations 2015 Found at: http://www.nepra.org.pk/Legislation/Regulations/NOTIFICATION\%20SRO\%20892\%20-2015.PDF

11 AEDB presentation at London 2015 conference 


\section{Power Sector Institutions}

\subsection{Executive and Regulatory Agencies}

The 2006 RE Policy sets out the key regulatory agencies with which developers will need to engage. Depending on the approach taken by the developer, these agencies will include most of the following, and interactions with them are further explained in Section 6:

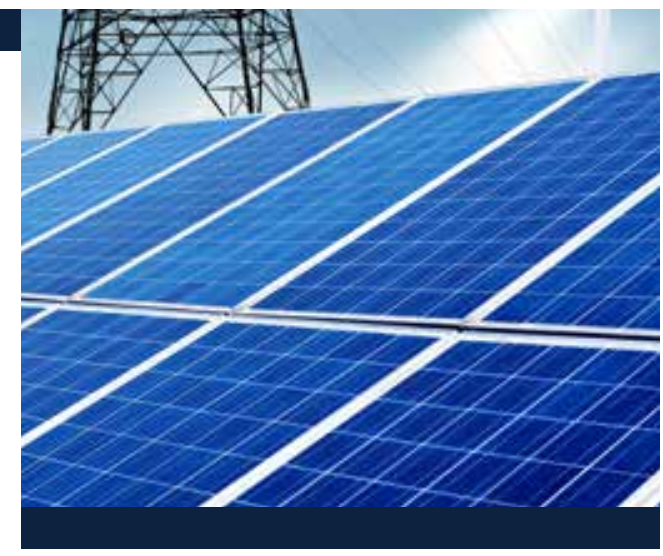

\subsubsection{NATIONAL ELECTRIC POWER REGULATORY AUTHORITY (NEPRA)}

Under the Regulation of Generation, Transmission and Distribution of Electric Power Act, 1997, NEPRA has been appointed as the sole regulator in the power sector. NEPRA was established to ensure a transparent, competitive and commercially-oriented power market in Pakistan. NEPRA issues generation licenses, establishes and enforces standards, approves investment and power acquisition programs of the utility companies, and determines investment tariffs for bulk generation and transmission and retail distribution of electric power.

\subsubsection{THE ALTERNATIVE ENERGY DEVELOPMENT BOARD (AEDB)}

The AEDB was established as an autonomous body with the aim of promoting and facilitating the exploitation of renewable energy projects in Pakistan. It has been designated as a 'one-window' facilitator at the federal level for processing solar projects of all sizes. The AEDB can issue a Letter of Intent (LOI), which is the first contract that a solar developer enters into with the AEDB. The AEDB also has developed the standard power purchase agreement (known as the Energy Purchase Agreement (EPA)) and the government support agreement (the Implementation Agreement (IA)). Both of these are available on its website. ${ }^{12}$

\subsubsection{PROVINCIAL AND AJK AGENCIES}

Provincial and Azad, Jammu \& Kashmir (AJK) governments support the development of renewable energy projects within their geographical jurisdiction either on their own or in collaboration with the AEDB. Most provincial agencies have also set up their own 'one-window' facilities to process solar projects at the provincial level. In the Northwest Frontier Province (now called KPK), the Sarhad Hydro Development Organization (SHYDO) is the government agency that issues the LOI. In Punjab, Sindh and Balochistan, their 'one-window' facility for processing solar applications is located within the Irrigation and Power departments. These provincial agencies also support renewables by expediting or facilitating allocation of land, permitting, and creating awareness of renewable energy.

\subsection{Off-takers/Power Purchasers}

Under the 2006 RE Policy, once the developer has secured all requisite approvals in the development process and signed an EPA, it is mandatory for the distribution utilities to purchase all of the electricity offered to them by renewable energy projects. A solar developer has essentially the following choices of power purchaser in Pakistan:

\subsubsection{CENTRAL POWER PURCHASING AUTHORITY (CPPA)}

The CPPA is the publically owned central off-taker. It is a department within the National Transmission and Despatch Company and is authorized under its license to purchase power at any voltage from renewable energy companies, including at $11 \mathrm{kV}$ and above.

12 Available here: http://www.aedb.org/index.php/ju-download/19-solar-standard-docs 


\subsubsection{DISTRIBUTION COMPANIES (DISCOS)}

- Public Distribution Companies

There are ten separately corporatized public distribution companies in Pakistan:

4.2.2.1. Lahore Electric Supply Company (LESC) supplies electricity to Lahore, Punjab; ${ }^{13}$

4.2.2.2. Gujranwala Electric Power Company (GEPCO) supplies electricity to Gujranwala, Punjab; ${ }^{14}$

4.2.2.3. Faisalabad Electric Supply Company (FESCO) supplies electricity to Faisalabad, Punjab; ${ }^{15}$

4.2.2.4. Multan Electric Power Company (MEPCO) supplies electricity to Multan in Punjab; ${ }^{16}$

4.2.2.5. Islamabad Electric Supply Company (IESCO) supplies electricity in the area from Attock to Jheleum, and from the river Indus to River Neelum in Kashmir; ${ }^{17}$

4.2.2.6. Peshawar Electric Supply Company (PESCO) supplies electricity to all civil districts of Khyber Pakhtunkhwa, Pakistan; ${ }^{18}$

4.2.2.7. Hyderabad Electric Supply Company (HESCO) supplies electricity to all of the province of Sindh except Karachi, Uthal, Sukkur, Ghotki, Khairpur, Kashmore/Kandhkot, Jacobabad, Shikarpur, Larkana, Kambar/Shahdadkot, Dadu and some parts of Jamshoro, Naushehro Feroze, Shaheed Benazirabad and Rahimyar Khan; ${ }^{19}$

4.2.2.8. Sukkur Electric Power Company (SEPCO) supplies electricity to the province of Sindh outside of Karachi, Uthal and those areas covered by HESCO; ${ }^{20}$

4.2.2.9. Quetta Electric Supply Company (QESCO) supplies electricity to the entire Balochistan Province; and ${ }^{21}$

\subsubsection{Tribal Areas Electricity Supply Company} (TESCO) provides distribution services in the Federally Administered Tribal Areas. ${ }^{22}$

\footnotetext{
13 http://www.lesco.gov.pk

$14 \mathrm{http}: / /$ www.lesco.gov.pk

15 http://www.fesco.com.pk

6 http://www.mepco.com.pk/htmls/INTRODUCTION.HTM

$17 \mathrm{http}: / /$ www.iesco.com.pk

8 peshawar electric supply company jobs 2015

19 http://www.hesco.gov.pk/newsite

$0 \mathrm{http}: / /$ www.sepco.com.pk

21 http://www.qesco.com.pk

22 http://www.tesco.gov.pk
}

More information about each of these DISCOs and their performance can be found in NEPRA's state of industry annual report. ${ }^{23}$ Details on their financial performance can be found on the websites referenced above. The most relevant public distribution company areas for solar developers are HESCO, SEPCO and MEPCO. Line maps of their networks are included in Annex 8. A solar developer may sell electric power to a distribution company at 132 $\mathrm{kV}$ and below.

\subsubsection{K-ELECTRIC}

In addition to these ten publicly owned distribution companies, there is K-Electric, the privately owned utility company responsible for the generation, transmission and distribution of electricity to Karachi and its adjoining areas in Uthal in Sindh and Bela district in Balochistan. K-Electric is listed on the Karachi, Lahore \& Islamabad Stock Exchange and is at the time of printing the only private-sector utility company in Pakistan. However, there are plans to further privatize other DISCOs in Pakistan. A solar developer may sell electric power to K-Electric at $132 \mathrm{kV}$ and below. As a private distribution company, K-Electric cannot benefit from a government guarantee for its IPP projects and power purchase agreements, and supporting guarantees must be negotiated directly with K-Electric. However, the tariff must still be approved by NEPRA. ${ }^{24}$ The Tariff Process Overview in this document does not apply to a negotiation with K-Electric and they must be contacted directly in relation to their processes and negotiations. In practice, IPPs will execute an energy purchase agreement (EPA) with either CPPA or K-Electric, which have a proven capacity and track record to manage the EPA negotiation process.

\subsection{Transmission}

National Transmission and Despatch Company: NTDC was organized to take over all the properties, rights and asset obligations and liabilities of $220 \mathrm{kV}$ and $500 \mathrm{kV}$ Grid Stations and Transmission Lines/Network. NTDC operates and maintains the $500 \mathrm{kV}$ Grid Stations, the 500 $\mathrm{kV}$ transmission line and the $220 \mathrm{kV}$ transmission lines in Pakistan. NTDC must review and approve evacuation and interconnection studies provided by a solar developer before a tariff for that developer can be approved and a grid connection agreement can be signed. A line map of the transmission network is included at Annex 8.

\footnotetext{
23 The 2014 report is available here: http://www.nepra.org.pk/Publications/State $\% 20$ of $\% 20$ Industry \%20Reports/State\%20of\%20Industry\%20Report \%202014.pdf 24 The 2014 report is available here: http://www.nepra.org.pk/Publications/State\%20of\%20Industry $\% 20$ Reports/State $\% 20$ of $\% 20$ Industry\%20Report $\% 202014$.pdf
} 


\section{Tariff Determination}

\subsection{Tariff Process Overview}

The 2006 RE Policy sets out three methods for tariff determination for grid connected utility scale renewables:

- Competitive bidding (solicited proposals)

- Direct negotiations for a cost-plus tariff (unsolicited proposals)

- FIT setting (known in Pakistan as an upfront tariff)

Unless it is a solicited competitive bid, NEPRA determines the level of tariff. The upfront tariff determination is a fixed tariff price determined by NEPRA with terms and conditions attached. Essentially, it is what is known internationally as a FIT and is referred to as such in this document. The FIT process is in the focus of this document. Although the other two methods are theoretically possible, they have not yet been used for the purposes of grid-connected, utility scale solar power projects.

\section{FIT PROCESS}

NEPRA will publish a notice of a FIT determination and any interested stakeholder may file a notice to intervene. The notice is usually accompanied by a draft FIT proposal. Interested parties may attend the hearing and submit amendments or proposals in relation to the suggested FIT. NEPRA will listen to the proposals and arguments at the hearing and will determine a FIT after taking these arguments into account. There have been three FIT determinations for solar so far, with the latest in December 2016. NEPRA determines the FIT on the basis of a number of principles, which are set out in the NEPRA Tariff Standards and Procedures Rules 1998.

In general, NEPRA assigns value to the project costs that developers would incur e.g. capex, opex, depreciation, finance costs (including interest and principal) and insurance, etc., and incorporates an assumption on a rate of return to the developer. The FIT is calculated on that basis and although the financial model NEPRA uses is not publically available, the component figures upon which its assumptions are based for calculation of the FIT are provided publicly in NEPRA's determination. Once the FIT final order is determined by NEPRA, parties may file motions for recalculation and review. NEPRA may review the FIT at its discretion.

Once the FIT is determined/approved, developers may apply for that FIT within 6 months of the date of publication of the tariff in the government official gazette ${ }^{25}$ and financial close must be achieved by the developer within a period of time of acceptance as determined by NEPRA and further described in Section 6. Decisions on tariffs are also published by NEPRA on its website. ${ }^{26}$

As has been the case in many other renewable energy programs, the Pakistan FIT for solar power projects has been declining since it was first announced in 2014, in line with international trends. This is to be expected (see Figure 6). A FIT that is set too high can be unsustainable in the long term.

\footnotetext{
25 Pursuant to section 31(4) of the Regulation of Generation, Transmission and Distribution of Electric Power Act, 1997 (XL of 1997) - Developers can subscribe to the government gazette here: http://. en.io.gov.mo/Services/Official-Gazette-Subscription.aspx 


\section{Declining Tariffs (US Cents/kWhr)}

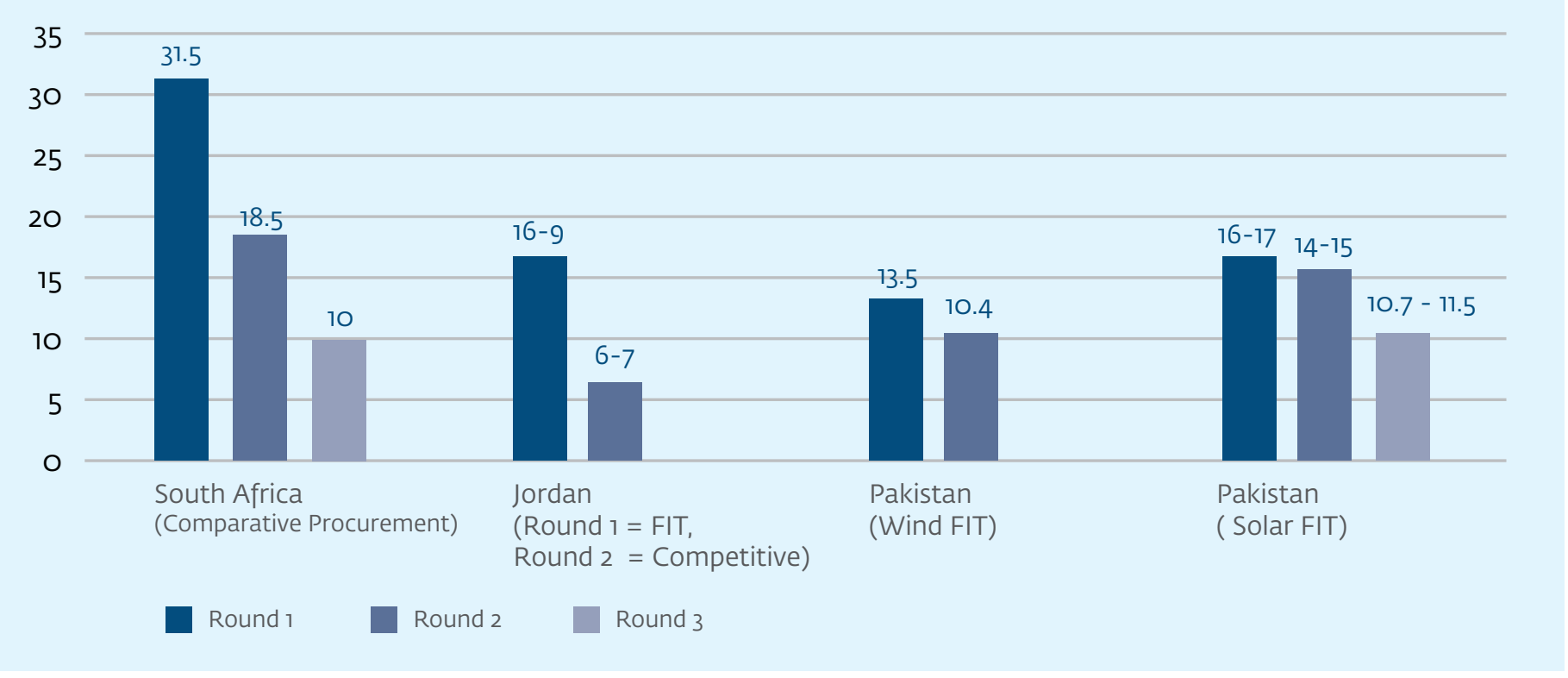

\subsection{FIT Assumptions, Adjustments and Indexations}

As set out above, NEPRA, in determining the FIT, assigns certain values to the project costs that the developers could incur in developing a solar project. There are certain assumptions, adjustments and indexations that are taken into account and allowed for these values and parts of the resulting tariff components, which need to be understood. A description of these is set out below:

\section{NORTH/SOUTH TARIFF DIVISION}

Pakistan has been divided into two zones based on solar irradiance levels. A higher tariff is applied for northern Pakistan where solar irradiance levels are lower, and a lower tariff is given for Southern Pakistan where it is hot and dry for most of the year, thus providing a higher yield than the north. This division has been accepted in all determinations to date and the areas covered are set out in the table below.

\section{TABLE 2: NORTH/SOUTH IRRADIANCE DIVIDE - LOCATIONS COVERED}

\begin{tabular}{|l|l|}
\hline & - Northern Punjab \\
Northern Pakistan & - Federally Administered Tribal Areas \\
& - Kyber Pakhtunkhwa \\
& - Islamabad Capital Territory \\
& - Azad Kahsmir \& Jammu, Gilgit-Baltistan) \\
\hline Southern Pakistan & - Balochistan \\
\hline & - Sindh \\
\hline
\end{tabular}




\section{BENCHMARK CAPACITY FACTORS.}

In calculating the tariff and how much energy would be generated by a solar power plant, NEPRA has used benchmark plant capacity factors. In the 2016 tariff, these are 17\% for northern Pakistan and 18\% for southern Pakistan (the Benchmark Capacity Factors).

\section{PROJECT COSTS AND INDEXATION}

NEPRA assigns assumed figures to certain project costs broken down into CAPEX and financing. The 2016 assumed figures are set out in Table 3 below.

\section{TABLE 3: 2016 TARIFF ASSUMED PROJECT COSTS}

\begin{tabular}{|c|c|c|c|}
\hline \multicolumn{4}{|c|}{ Project Costs (USD/MW) } \\
\hline Costs & $>50 \mathrm{MW} \leq 100 \mathrm{MW}$ & $>20 \mathrm{MW} \leq 50 \mathrm{MW}$ & $>1 \mathrm{MW} \leq 20 \mathrm{MW}$ \\
\hline EPC Costs & $1,034,000$ & $1,054,680$ & $1,075,360$ \\
\hline EPC Costs (including Degradation) & $1,071,431$ & $1,092,859$ & $1,114,288$ \\
\hline Land & 23,810 & 23,810 & 23,810 \\
\hline Project Development Cost & 36,658 & 38,490 & 40,320 \\
\hline Insurance During Construction & 10,714 & 9,107 & 7,429 \\
\hline Capex & $1,142,613$ & $1,164,266$ & $1,185,846$ \\
\hline \multicolumn{4}{|l|}{ Financing } \\
\hline Financing Fees \& Charges & 29,994 & 30,562 & 31,128 \\
\hline Interest During Construction & 21,334 & 16,043 & 10,565 \\
\hline Subtotal & 51,328 & 46,605 & 41,693 \\
\hline Total Project Cost & $1,193,940$ & $1,210,871$ & $1,227,540$ \\
\hline
\end{tabular}

NEPRA recognizes that a large amount of the project will be contracted from abroad. The reference exchange rate is PKR 105/US\$. Since the exact timing of payment to the EPC contractor is not known at the time of tariff determination by NEPRA, under the 2016 Tariff, an adjustment for relevant foreign currency fluctuation for $90 \%$ of the foreign component of the EPC contract price will be allowed against the reference exchange rate on the basis of monthly average exchange rates prevailing on 1st day of each month during the construction period. The developer is required to provide all the necessary relevant details along with documentary evidence. The adjustment shall be made only for the currency fluctuation against the reference exchange rate. See Annex 3 for more details on the indexation mechanism.

\section{OPERATIONS AND MAINTENANCE}

As with project costs, NEPRA assumes a certain cost for Operations and Maintenance (O\&M). In the 2016 tariff calculation, an O\&M component of US \$26,541/MW was assumed.

NEPRA allows a foreign and local operations and maintenance (O\&M) tariff component. In the 2016 tariff, the local component is $70 \%$ of the O\&M tariff component (set out in Table 5) and the foreign component is $30 \%$. The O\&M component of the tariff will be adjusted on account of local inflation (based on the consumer price index, or CPI), foreign inflation (US CPI), and the quarterly exchange rate on 1st July, 1st October, 1st January and 1st April based on the latest available information with respect to CPI notified by the Pakistan Bureau of Statistics (PBS), the US CPI issued by US Bureau of Labor Statistics, and the National Bank of Pakistan. The mechanism for this indexation is set out in Annex 3. 


\section{DEBT}

In calculating the tariff, NEPRA allows different premiums depending on whether the solar developer uses foreign or local debt. Under the 2016 Tariff, the foreign debt allowed is London Inter Bank Offered Rate (LIBOR), 0.31\%, plus a premium of $4.5 \%$ for foreign loans. The local debt is Karachi Interbank Offered Rate (KIBOR), which as of 28th December 2015 was $7 . .32 \%$, plus 3\% on quarterly basis, as shown in Table 4 . If there are any savings in the premium, these will be shared between the developer and the purchaser (60:40). The interest on the fixed loan will remain unchanged unless there is a variation in the 3-month LIBOR. Each quarter, if there is a variation in LIBOR, an adjustment to the interest portion of the tariff may be made. This adjustment can be positive or negative. The mechanism for this indexation is set out in Annex 3.

The tariff assumes a debt-to-equity ratio of $75: 25$, a loan tenor of 10 years, and quarterly repayments.

TABLE 4: FOREIGN VERSUS LOCAL DEBT ALLOWANCE 2016 TARIFF 27

\begin{tabular}{|l|c|c|}
\hline \multicolumn{2}{|c|}{ NEPRA Foreign versus Local Debt Allowances } \\
\hline & Foreign Debt & Local Debt \\
\hline Debt Tenor (years) & 10 & 4 \\
\hline Repayment (Qtrly) & 4 & \\
\hline LIBOR & $0.37 \%$ & $7.32 \%$ \\
\hline KIBOR (actual) & & $3.00 \%$ \\
\hline Spread & $4.50 \%$ & $\mathbf{1 0 . 3 2 \%}$ \\
\hline Total Debt Cost & $\mathbf{4 . 8 1 \%}$ & \\
\hline
\end{tabular}

\section{CONSTRUCTION PERIODS}

NEPRA determined that the targeted maximum construction period after financial close is 8 months, 10 months and 12 months for $>1 \mathrm{MW} \leq 20 \mathrm{MW},>20 \mathrm{MW} \leq 50 \mathrm{MW}$ and $>50 \mathrm{MW} \leq 100 \mathrm{MW}$ projects respectively. No adjustment will be allowed in this tariff to account for the financial impact of any delay in project construction. However, the failure of the developer to complete construction within the stipulated time will not invalidate the tariff granted to it. See Section 6.3.1 for more discussion on construction periods in the context of the project documents.

\section{RETURN ON EQUITY}

The return on equity has been set at $17 \%$ before taxes for every tariff determination by NEPRA. After Commercial Operations Dated (COD), the Return on Equity (ROE) component of the tariff may be quarterly indexed on account of variations in the PKR/US \$ exchange rate. The formula for this is set out in Annex 3.

\section{INSURANCE AND SINOSURE FEE}

A portion of the EPC costs is allowed for insurance during construction as set out in Table 3 above. Insurance during construction will be re-established on the basis of actual project financing and weighted average quarterly LIBOR/ KIBOR and applicable premiums, $4.5 \%$ and $3 \%$ respectively. Any savings in premium must be shared in the ration of 60:40 between the power purchaser and the developer.

During the operation period, an actual insurance cost of a maximum of $1 \%$ of the EPC cost may be charged to the power purchaser. The actual insurance cost for the minimum coverage required under contractual obligations with the off-taker not exceeding $1 \%$ of the EPC cost is be treated as a pass-through ${ }^{28}$. The insurance component of reference tariff shall be adjusted annually as per actual upon production of authentic documentary evidence. The formula for calculation of this insurance adjustment is set out in Annex 3. 
A number of large-scale projects are seeking funding from Chinese financial institutions and a condition for financing these projects is that financial institutions are required to obtain coverage from the China Export Credit \& Insurance Corporation (Sinosure) for specific risks. NEPRA has decided to allow the Sinosure fee for the solar power projects under the upfront tariff. A Sinosure fee of $7 \%$ of the total debt servicing may been included in the project cost. Project cost will be adjusted at the time of COD on the basis of the actual Sinosure fee subject to a maximum of $7 \%$ of total debt servicing may be passed through as a cost to the power purchaser under the tariff.

\section{TAXES}

Up to 2016, there was an allowed taxes and duties rate in the EPC component. This was US\$ 47,365/MW and could be adjusted as per the actual rate at the time of COD stage adjustment of the tariff on the basis of verifiable documentary evidence. This was not mentioned in the 2016 tariff and the adjustment would not seem to apply any longer.

The 2016 determination does state that if the Project Company is obligated to pay any tax on its income from generation of electricity or any duties and/or taxes, not being of a refundable nature, are imposed upon the company, the exact amount will be reimbursed by CPPA/DISCO on production of original receipts. See Section 8 below for more details on taxes.

\subsection{Tariff}

Based on the assumptions set out in Section 5.2, the 2016 Tariff and its components were determined as set out in Table 5 below. The reference tariffs set out in Table 5 are based on $100 \%$ foreign financing and if local financing is used, a KIBOR $+3 \%$ premium will apply as discussed in Section 5.2. Developers should note that tariffs are paid on a stepdown basis, with a higher tariff for the first 10 years of the project.

\section{TABLE 5: 2016 REFERENCE TARIFFS}

\begin{tabular}{|c|c|c|c|c|}
\hline \multicolumn{4}{|c|}{ Specified Reference Feed-in Tariff - NORTH } & \multirow{3}{*}{ Indexations } \\
\hline \multirow{2}{*}{ Category } & $>1 \leq 20 \mathrm{MW}$ & $>20 \leq 50 M W$ & $>50 \leq 100 \mathrm{MW}$ & \\
\hline & US cent/ kWh & US cent/ kWh & US cent/ kWh & \\
\hline$O \& M$ & 1.7823 & 1.7826 & 1.7823 & CPI, US CPI, PKR/US \$ \\
\hline Insurance & 0.7483 & 0.7338 & 0.7194 & Actual on annual basis \\
\hline ROE & 3.7058 & 3.7054 & 3.7029 & PKR/US \$ \\
\hline Debt Servicing (10 Yrs - Foreign) & 7.8242 & 7.7179 & 7.6100 & PKR/US \$ \& LIBOR/KIBOR \\
\hline Total Tariff (1 - 10 Yrs $)$ & 14.0604 & 13.9394 & 13.8146 & \\
\hline Total Tariff (11 - 25 Yrs) & 6.2363 & 6.2215 & 6.2046 & \\
\hline Levelized Tariff & 11.5327 & 11.446 & 11.356 & \\
\hline \multicolumn{4}{|c|}{ Reference Feed-in Tariff - SOUTH } & \multirow{3}{*}{ Indexations } \\
\hline \multirow{2}{*}{ Category } & $>1 \leq 20 \mathrm{MW}$ & $>20 \leq 50 \mathrm{MW}$ & $>50 \leq 100 \mathrm{MW}$ & \\
\hline & US cent/ kWh & US cent/ kWh & US cent/ kWh & \\
\hline O\&M & 1.6832 & 1.6832 & 1.6832 & CPI, US CPI, PKR/US \$ \\
\hline Insurance & 0.7067 & 0.6930 & 0.6795 & Actual on annual basis \\
\hline ROE & 3.4999 & 3.4995 & 3.4971 & PKR/US \$ \\
\hline Debt Servicing (10 Yrs - Foreign) & 5.0022 & 4.9343 & 4.8652 & PKR/US \$ \& LIBOR/KIBOR \\
\hline Total Tariff (1 - 10 Yrs) & 13.2792 & 13.1650 & 13.0470 & \\
\hline Total Tariff (11 - 25 Yrs) & 5.8898 & 5.8758 & 5.8598 & \\
\hline Levelized Tariff & 10.892 & 10.8101 & 10.7251 & \\
\hline
\end{tabular}




\section{REVENUE SHARING FOR EXCESS GENERATION}

NEPRA has structured each FIT such that any benefit from excess generation (over the assumed Benchmark Capacity Factors) is shared with the power purchaser and, by extension, the consumers. Under the 2016 tariff, Table 6 sets out the adjustments to payments to developers for generation in excess of the Benchmark Capacity Factors:

\section{TABLE 6: 2016 EXCESS GENERATION TARIFFS}

\begin{tabular}{|c|c|}
\hline & Excess Energy \\
\hline Plant Factor (North/South) & Percent of Tariff Chargeable \\
\hline Above $17 \% / 18 \%$ to $18 \% / 19 \%$ & $80 \%$ \\
\hline Above $18 \% / 19 \%$ to $19 \% / 20 \%$ & $90 \%$ \\
\hline Above $19 \% / 20 \%$ & $100 \%$ \\
\hline
\end{tabular}

The sharing is subject to a maximum of $19 \%$ (North) $20 \%$ (South). This maximum is set to encourage developers to use the most efficient equipment possible. These payment adjustments are calculated on a yearly basis. For further, discussion on this and shortfall energy below benchmark capacity factors in any given year, see Section 6.3.1 below.

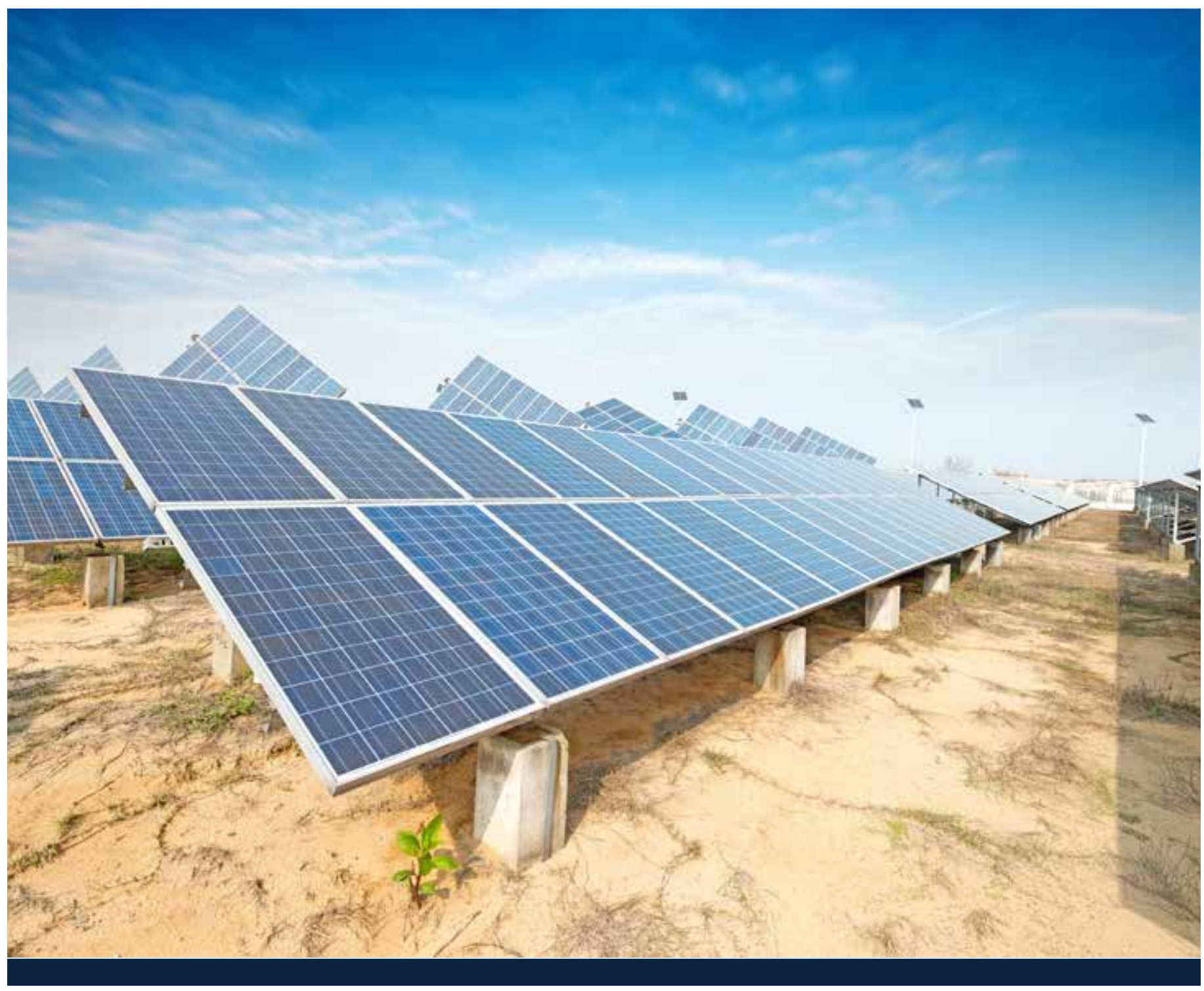




\section{Development Process under FIT.}

This section sets out the process in Pakistan for development of a project under the Feed-in-Tariff (FIT).

The 2006 RE Policy lists the key steps and requirements from registration through to financial close for renewable energy projects in Pakistan if they wish to opt for the FIT.

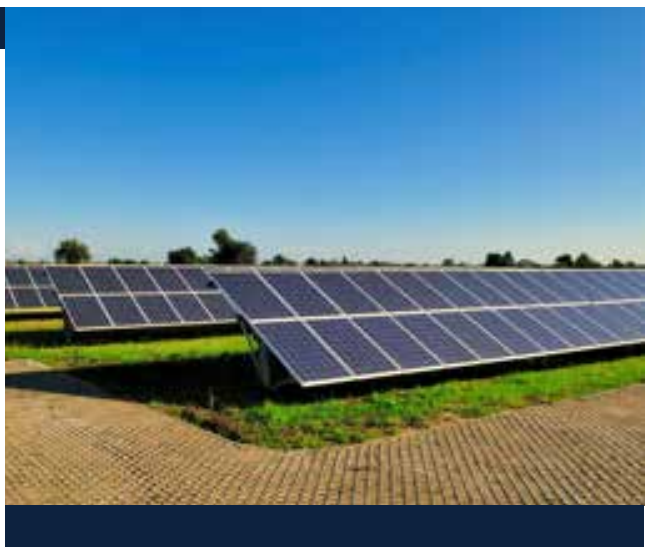

\section{Stages and Indicative Timelines}

There are three key stages for developing an unsolicited solar power project in Pakistan, as follows:

\section{- STAGE 1: LETTER OF INTENT (LOI)}

Obtaining the LOI takes about one to two months according to the AEDB and the provincial agencies. Identification of land may delay the process for the developer.

\section{- STAGE 2: LOI TO LETTER OF SUPPORT (LOS)}

The LOI from the AEDB is 18 months in duration. This can be shorter if the LOI is issued by the provincial agencies.

\section{- STAGE 3: LETTER OF SUPPORT TO FINANCIAL CLOSE}

The Letter of Support is issued for 12 months from the date that NEPRA approves the tariff. The developer must achieve financial close within that time unless an extension is obtained.

This section sets out the processes, procedures and costs for each of these stages in detail.

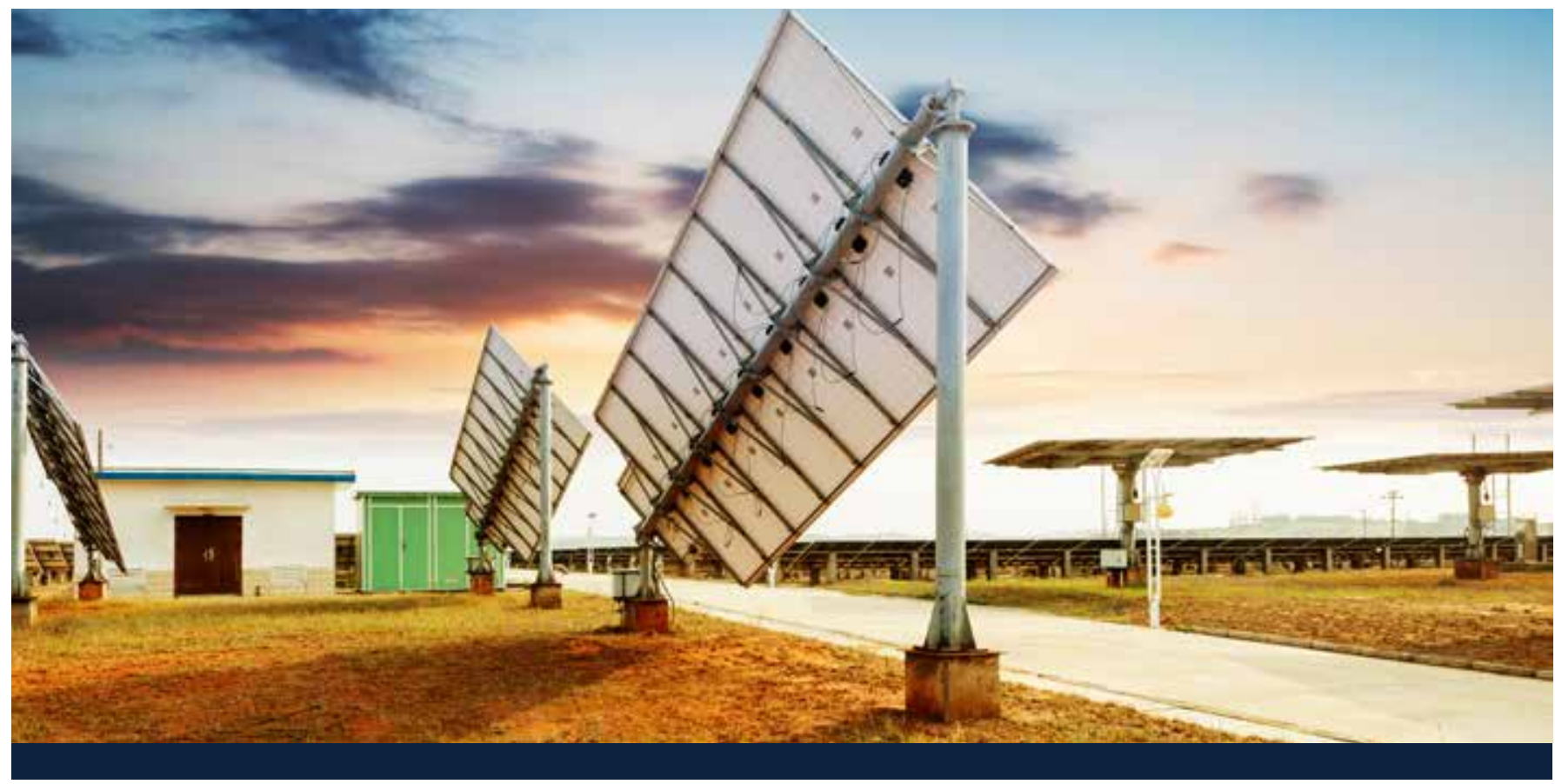




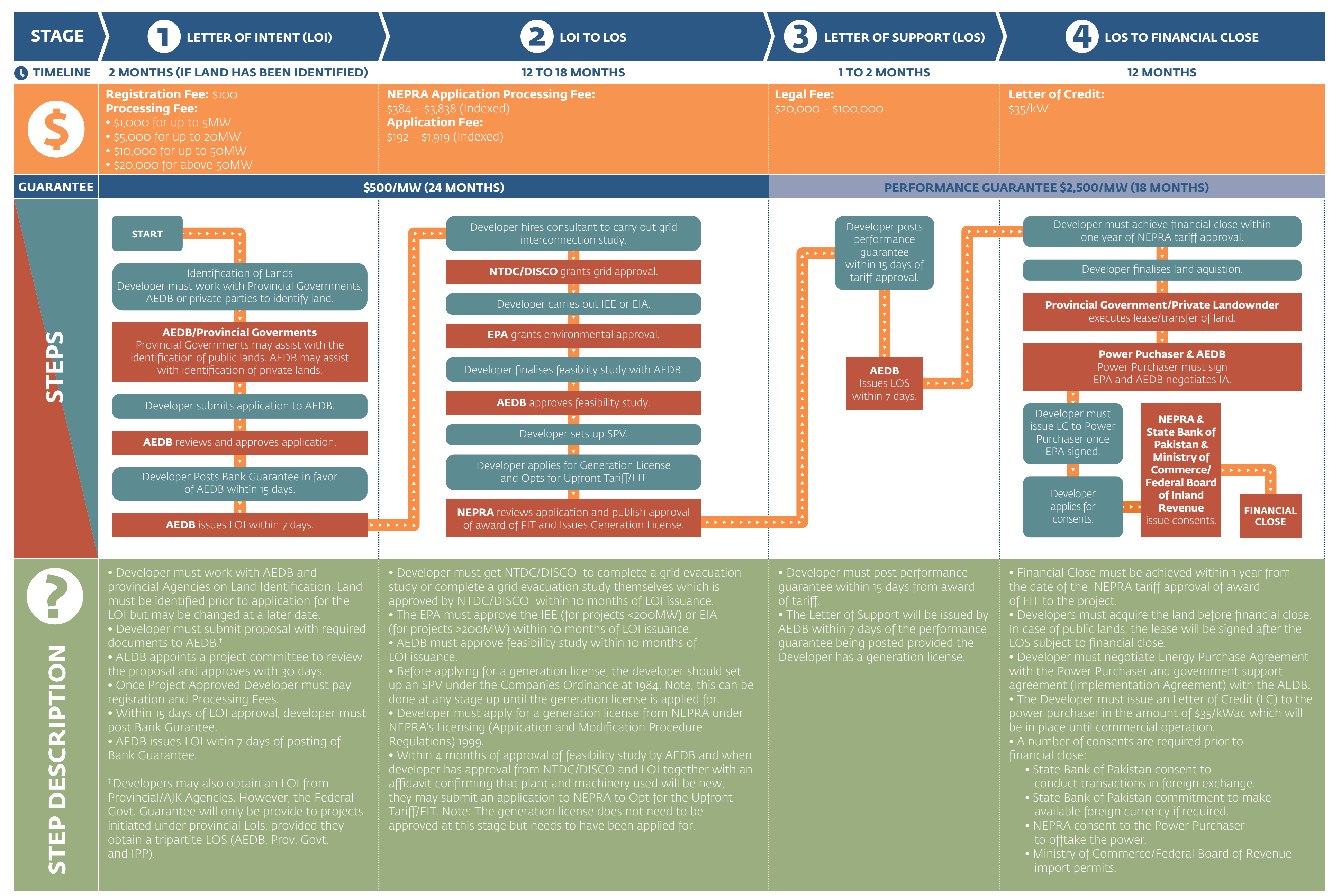

developer government authority 
FIGURE 7: PROCESS MAP FOR SOLAR DEVELOPERS 29 


\subsection{Stage 1: Letter of Intent}

The first step in developing a solar tariff under the solar FIT/upfront tariff scheme is to secure a Letter of Intent (LOI) from the AEDB or other relevant provincial agencies.

\subsubsection{AEDB OR PROVINCIAL AGENCY}

Although the majority of international and local RE project sponsors apply for the LOI through the AEDB, provincial and territorial agencies have the power to issue LOIs essentially on the same terms for projects in their respective jurisdictions. The relevant provincial agencies are:

- Punjab Power Development Board (PPDB) / Energy Department of Punjab

- Directorate of Alternate Energy / Energy Department of Sindh

- Balochistan Power Development Board (BPDB) / Department of Energy, Balochistan

- Pakhtunkhwa Energy Development Organization (PEDO) / Energy \& Power Department, KPK

- AJK Private Power Cell (PPC) / Azad Jammu \& Kashmir Region

Developers may decide which pathway to LOI they would like to pursue. However, the AEDB has the advantage of extensive experience of executing most of the renewable energy projects in Pakistan. If developers go through the AEDB, they will still be required to interact with the provincial agencies if they intend to procure public lands. If they decide to work through the provincial agencies, the Government Guarantee (under the Implementation Agreement) will only be provided to projects initiated under provincial LOIs, provided they obtain a tripartite LOS (AEDB, Prov. Govt. and IPP). ${ }^{30}$

Provincial governments vary with regard to the timelines and procedures for obtaining the LOI. For example, if a developer wishes to obtain the LOI from the Punjab Power Development Board, the timelines are more aggressive and the costs and procedures are different. See figure 8 below.

In Sindh, the government follows the AEDB procedures and timelines and utilizes the AEDB standard LOI. However, if the solar power project developer is obtaining public land, the energy department in Sindh will include a provision in the LOI that states that it will assist in procuring the land.

Unless otherwise indicated, process details in this document refer to an application through the AEDB for an LOI.

30 Amendment to the 2006 RE Policy May 2015. This contrasts with the procedures in the Punjab Power Generation Policy 2006 (as amended in 2009)

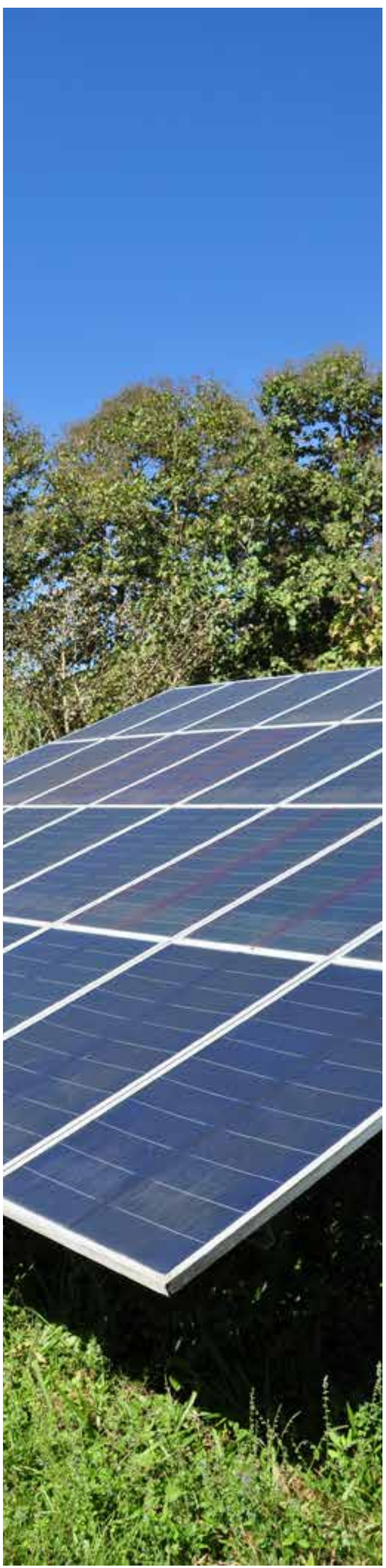


FIGURE 8: CONTRASTING PROCEDURES IN OBTAINING LOI THROUGH PUNJAB POWER DEVELOPMENT BOARD (PPDB) VERSUS THE AEDB

PUNJAB LOI TO LOS PROCESS 31

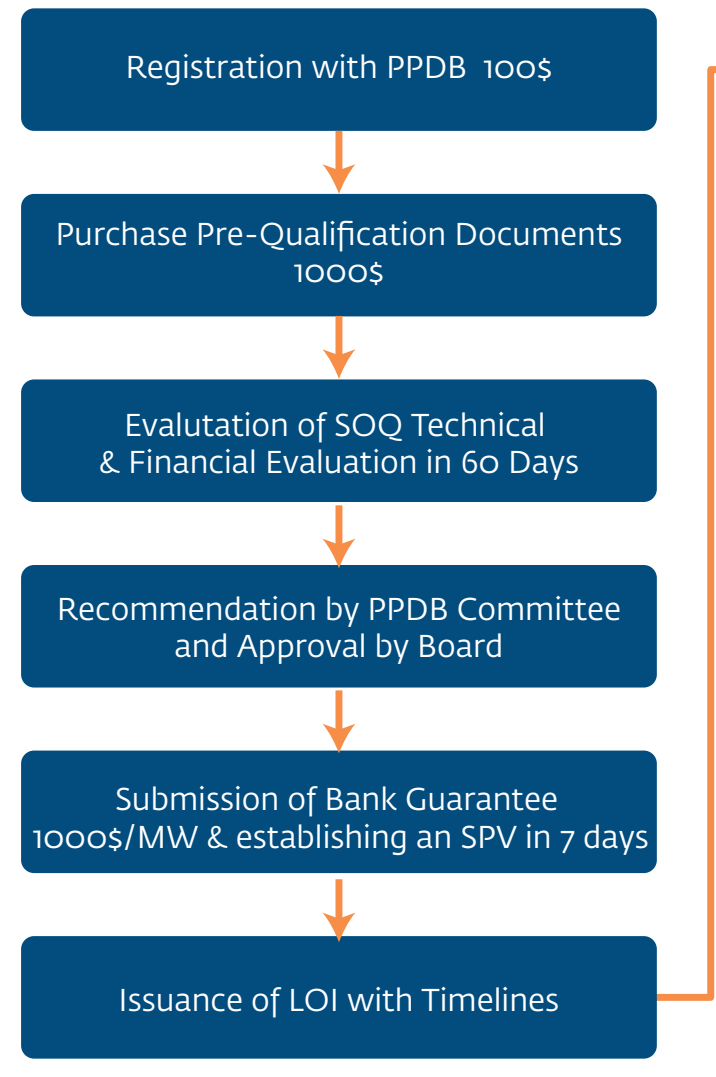

\section{AEDB PROCESS LOI TO LOS PROCESS}

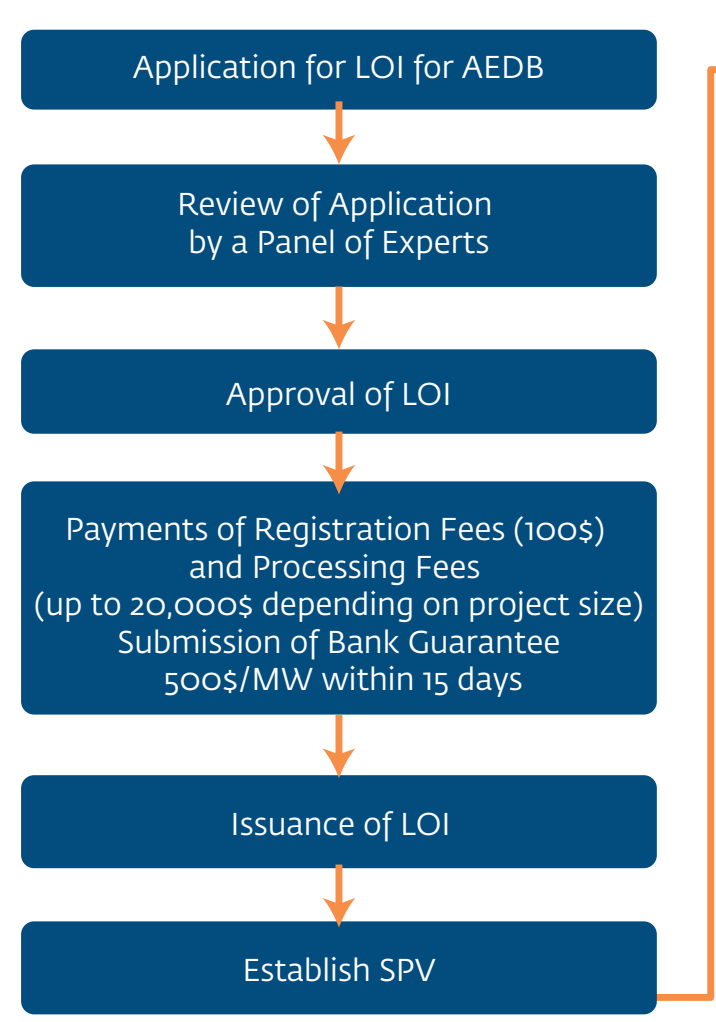

Submission of Feasibility Study and approval of Panel of Experts in PPDB

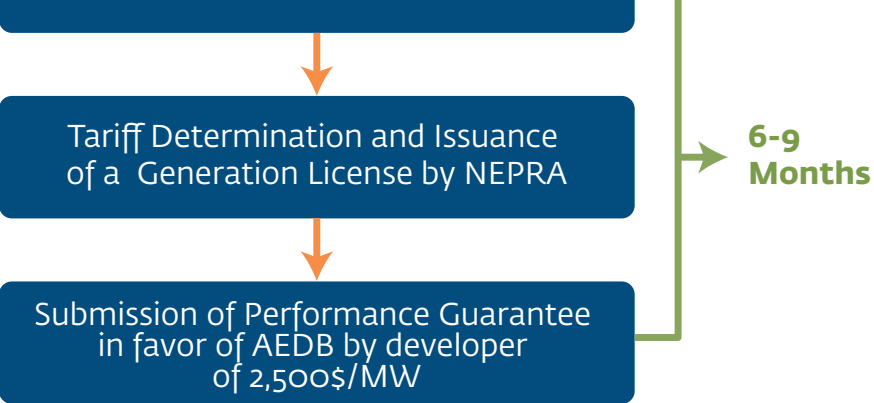

Issuance of LOS by PPDB and AEDB (If public lands, lease agreement signed)

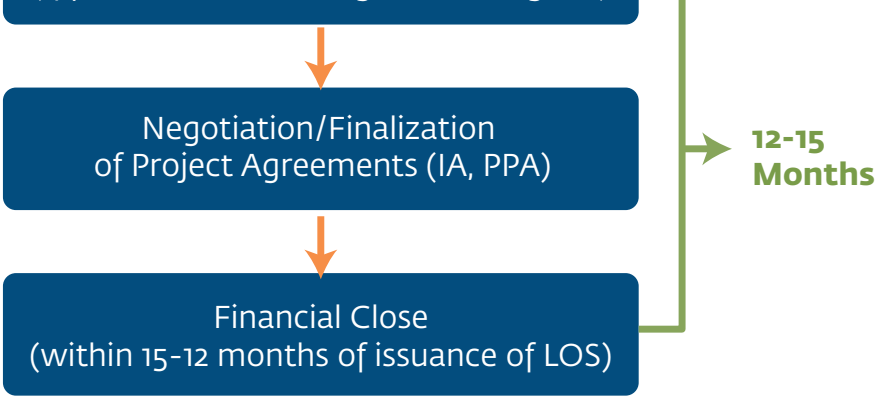

Submission of Feasibility Study and approval of Panel of Experts in AEDB

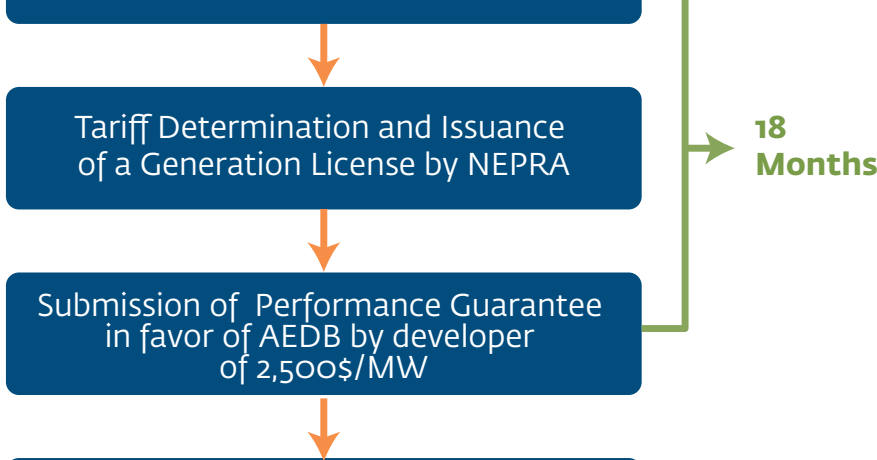

Issuance of LOS by AEDB

(if public lands, lease agreement signed)

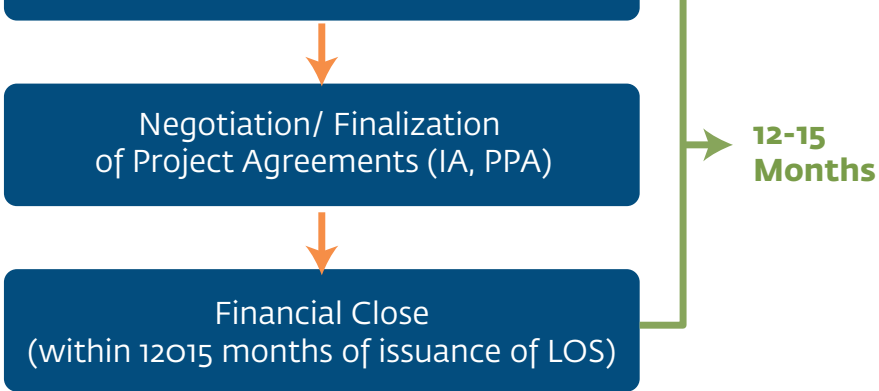

31 There is some ambiguity as to whether the LOS issued by Punjab can be different to the standard document issued by AEDB. The PPDB has suggested that their timelines are more aggressive and that 6 months is required for financial close. AEDB is clear that once there is a tripartite LOS (i.e. where a government guarantee is required) their standard LOS is used and the guarantee is issued in favour of AEDB and not the provincial government. 


\subsubsection{IDENTIFICATION OF LAND}

Although land title is not required for issuance of the LOI and indeed the developer may, once the LOI is issued, apply to change the site location, the developer must identify lands in its application to the AEDB for an LOI. Identifying land is not straightforward. It is advised to start the process of identification of lands as early as possible.

Solar project developers interested in developing solar power in Pakistan have two options to secure land: through direct negotiations with landowners or with the support of provincial governments.

\section{PUBLIC LANDS}

Public lands lie solely within the remit of the Provincial Governments. The conditions for the lease of lands vary depending on the provincial government. Although the resource in other parts of Pakistan is much more robust, the majority of activity in relation to solar power projects is in the provinces of Punjab and Sindh, where the vast majority of the load exists. Both of these governments have issued notifications of the procedures for lease of government land for solar projects in those provinces discussed in Section 6.2.1 below.

One of the key differences between Punjab and Sindh is that Punjab must advertise the property before allocating it to any developer and Sindh gives land that it has identified on a first come, first served basis. Both provinces have identified 'one-window facilities' for developers. Sindh, in particular, has identified a number of solar park areas that it intends to develop and will include a provision in the LOI to support the developer to obtain that public land. The developer may also identify its own land and inquire into obtaining it with the Government of Sindh.

Developers may also partner with companies/sponsors that have already been allocated public lands. Both the Government of Sindh and Pakistan have begun digitalizing public lands, which may help developers. See Figures 9 and 10 for maps of Punjab and Sindh. ${ }^{32}$ Also, see Annex 8 which contains a transmission map of the land corridor in Sindh where land for solar projects has also been allocated. Further details on land acquisition are in Section 6.2.1 below.

If developers intend to lease public lands, they are advised to contact the provincial agencies as soon as possible. The contact details for the 'one-window facilities' in Punjab and Sindh are set out below:

\section{Engr. Mehfooz A. Qazi}

Energy Department

Government of Sindh

3rd Floor State Life Building No. 3

Dr. Zia-uddin Road, Opp: CM House Karachi

Email: mehfoozkazi@yahoo.com

www.sindhenergy.gov.pk

\section{Managing Director}

Punjab Power Development Board

Old Anarkali Lahore

Ph: +92 4299212794

Email: ceppunjab@gmail.com

http: irrigation.punjab.gov.pk

or

\section{S.Ashar Abbas}

Energy Department

Government of the Punjab

+923218408099

dsec.ed@energy.punjab.gov.pk

32 The DISCOS are required to digitize their networks under their distribution licenses. This process has begun but the information is not publically available. NEPRA State of Industry Report 2014, 


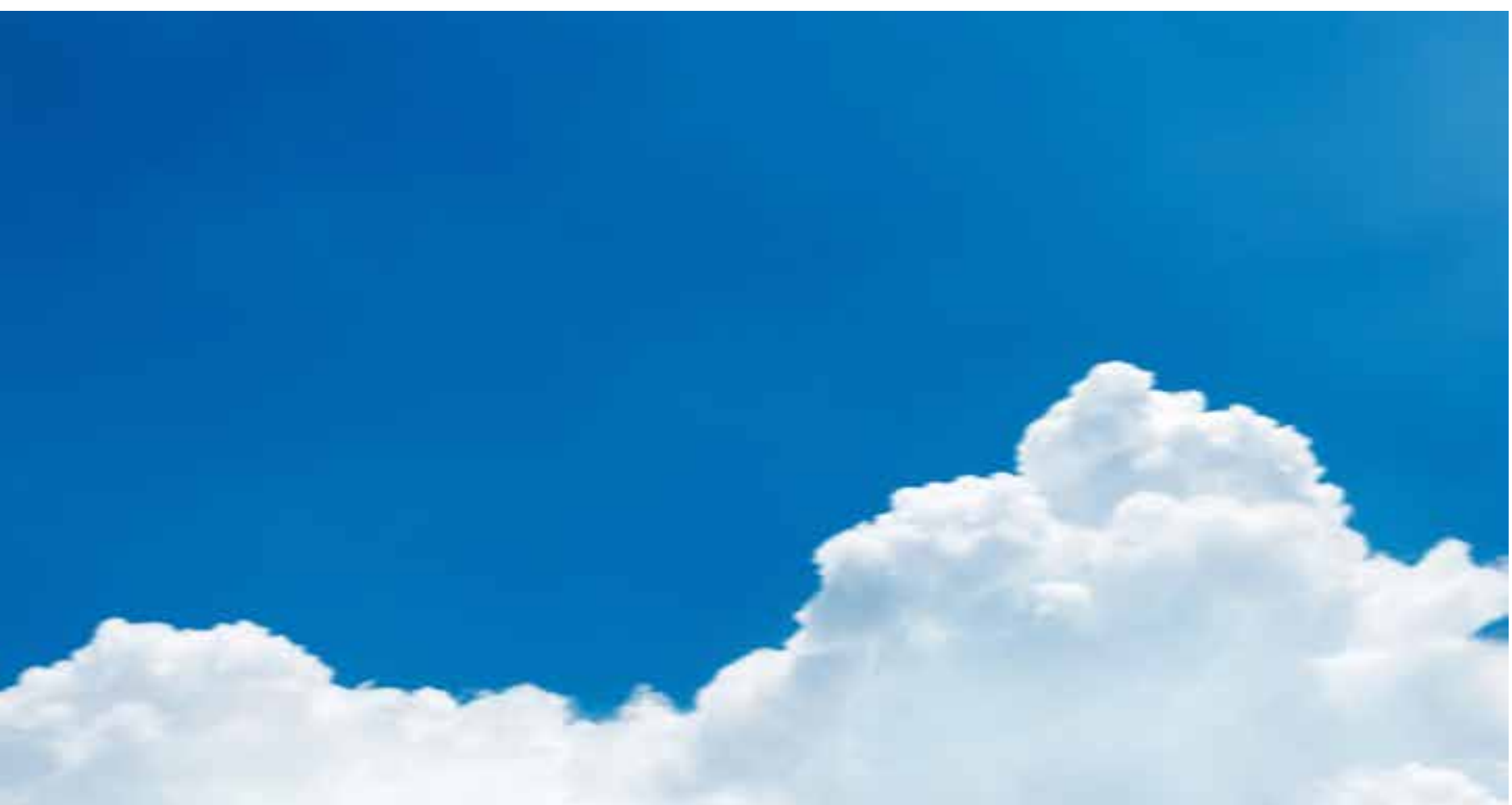

w

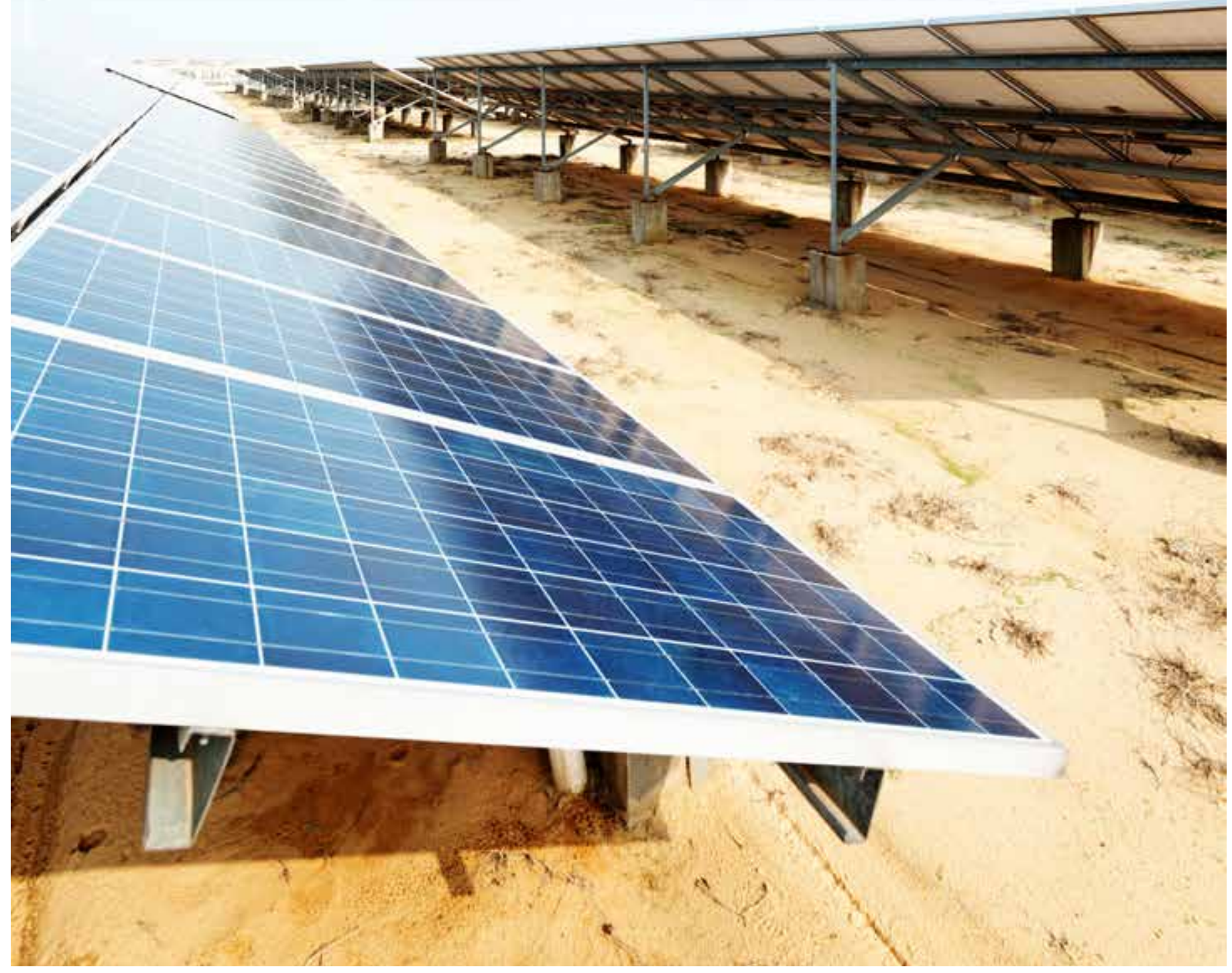


FIGURE 9: SOLAR IRRADIANCE MAP OF PUNJAB

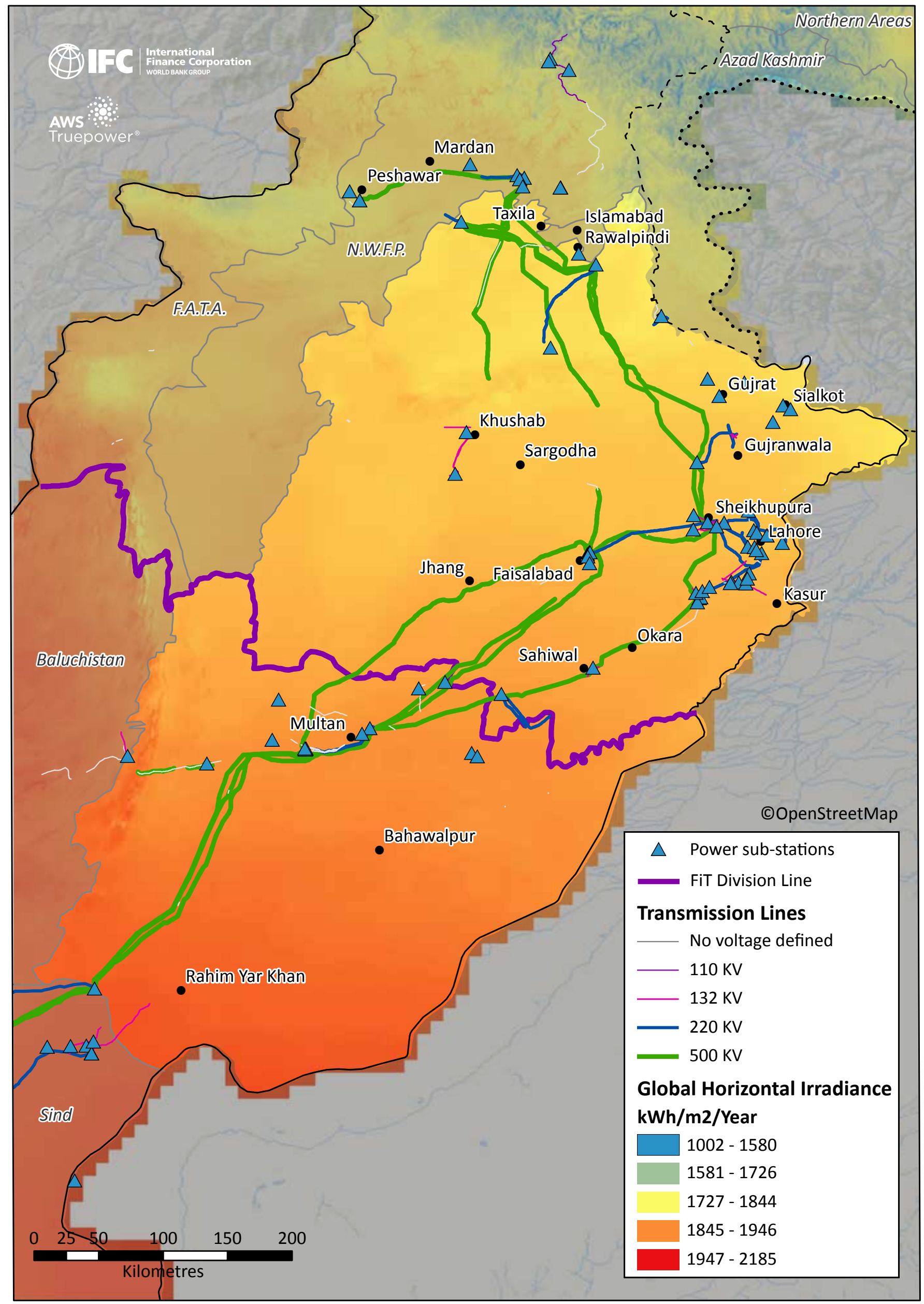


FIGURE 10: SOLAR IRRADIANCE MAP OF SINDH

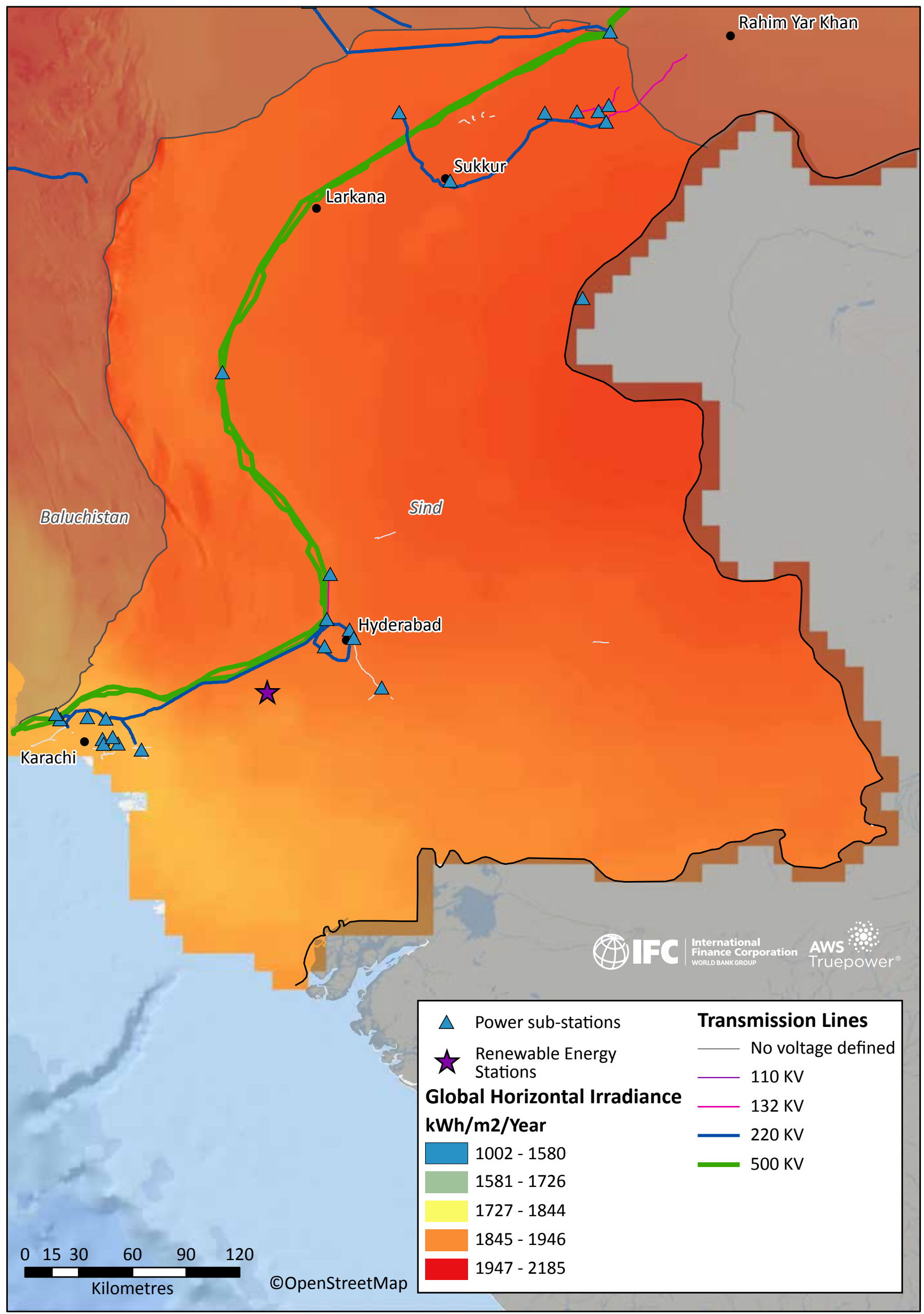




\section{PRIVATE LANDS}

Developers may also negotiate directly with landowners for private lands. Developers may find these lands themselves or approach the AEDB. As the AEDB has no jurisdiction over provincial lands, it encourages developers to purchase lands through private treaty. The AEDB has worked with NTDC to identify a number of sites or areas near to substations that could be developed. The AEDB has identified private sites close to transmission lines in Balochistan, KPK, Sindh and Punjab. Each of these sites can take a maximum of 200-300 MW. The AEDB is encouraging projects to stay below 50 MW so that they can utilize the $132 \mathrm{kV}$ network and that NTDC will not need to build large transmission lines purely for the evacuation of solar power as it was required to for the 1000 MW QA Solar Park in Punjab. The estimated market rate for private lands is between $\$ 1000$ and $\$ 4000$ an acre. Approximately 10 developers have been able to purchase lands under this procedure.

Contact Information for the AEDB:

Irfan Yousuf

AEDB

2nd Floor, OPF Building,

Shahra-e-Jumhuriat, G-5/2,

Islamabad.

Tel: +92 51 9241288; +92 22360-61

Mob: +92 3005220122

\subsubsection{THE AEDB LOI APPLICATION PROCESS}

It takes approximately two months to secure an LOI. The AEDB will begin processing the LOI even if exact lands have not been identified. To obtain an LOI, a set of documents referred as the "proposal" in the 2006 RE Policy must be submitted by the sponsor. The proposal package should include the following, at a minimum:

i. A Statement of Qualification of the project sponsors along with relevant corporate and sponsor profiles, plus proof of financial capacity to undertake the project.

ii. List of relevant corporate experience of the project sponsor(s).

iii. Proposed project location with GPS coordinates. The project site has to be located in an area with no adverse environmental effects. This site location can be changed at a later stage.

iv. Proposed net installed capacity (MW) and expected annual energy output (MWh) based on solar resource available at the site

v. Proposed basic outline of plant and structures

vi. A brief summary of the project implementation plan covering proposed milestones for project preparation, implementation and completion date. This plan may include aspects in relation to technology, human resource and project financing options.

vii. Estimated distance of the grid from the proposed site and the estimated distance from the nearest $132 \mathrm{kV}$ or $11 \mathrm{kV}$ line and the grid station.

viii. An indication of land availability/acquisition for the proposed project, which will be secured before the expiry of the LOI.

The soft copy of the complete proposal can be emailed to the AEDB at: solarsection@gmail.com or it may be provided directly to Solar Section, Alternate Energy Development Board, 2nd Floor, OPF Building, Shahrah-e-Jamhuriat, G-5/2, Islamabad, Pakistan. Tel: +92 0519222360 - 61. 
The submitted proposals shall be examined by a Project Committee appointed by the AEDB. After careful review of the proposal, the designated committee will inform the concerned part of the approval (or other required follow-up actions, as required) within 30 days.

Upon approval of the LOI by the Committee, the sponsor shall pay the AEDB a registration fee of US\$ 100 and project facilitation/processing fees, depending on the size of the project, as follows:

- US\$ 1,000 for up to $5 \mathrm{MW}$

- US\$ 5,000 for up to $20 \mathrm{MW}$

- US\$ 10,000 for up to $50 \mathrm{MW}$

- US\$20,000 for above $50 \mathrm{MW}$

Payment should be made by bank draft or payment order made out to the AEDB.

A bank guarantee of US \$500/MW shall be posted to the AEDB within 15 days after obtaining approval from the AEDB. Once the processing fees and bank guarantee are received, the final LOI will be issued within seven days.

\section{TERMS OF AEDB LOI}

The LOI is signed by the sponsors of the project and the AEDB. The AEDB LOI is a publically available document. ${ }^{33}$

The term of the standard LOI is 18 months while the validity of the bank guarantee must be for 24 months ( 6 months beyond the LOI duration). Within the standard LOI, there is a one-time provision for an extension to the LOI for an additional six months by doubling the amount of the bank guarantee, i.e. US\$ 1,000/MW. However, in practice, it is not uncommon to secure repeated extensions due to various factors that delay the approvals and development process that may be beyond the sponsors' control.

If the award of the tariff is delayed beyond the initial validity of the LOI, the Project Company shall extend the bank guarantee and the expiry date of the LOI will be extended. The aforementioned extension process may be repeated if the tariff is not announced (including on any review petition filed by the Project Company). Such review (if any) is to be filed within the period prescribed in the NEPRA (Tariff Procedures and Standards) rules up to 15 days before the then prevailing expiry date.

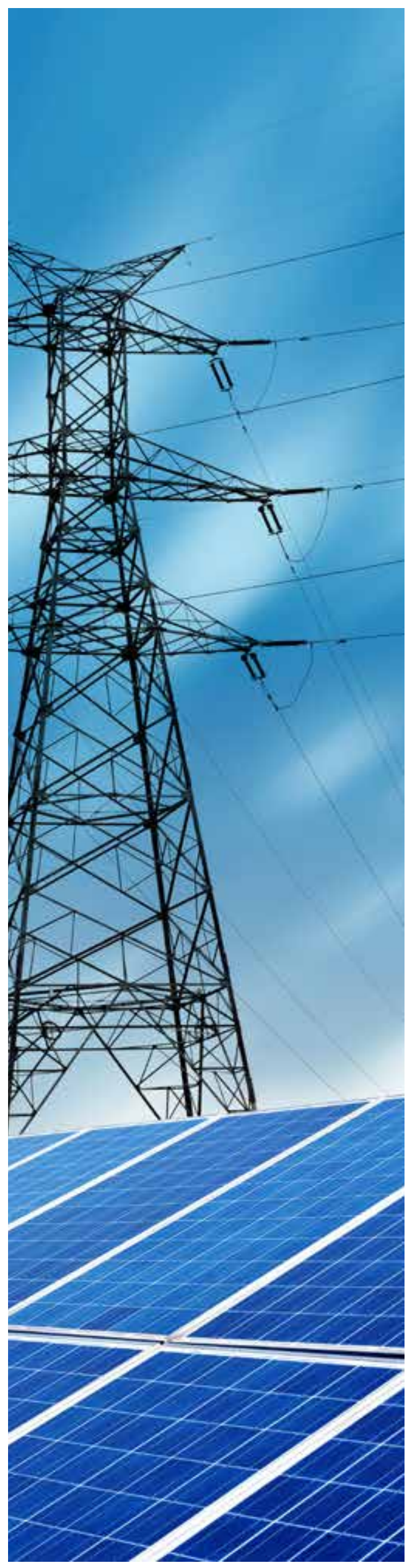




\subsection{Stage 2: LOI to LOS}

The milestones that must be reached before an LOS can be issued are set out in a schedule to the LOI. These milestones and the timelines within which they are required to be met as set out in the LOI are in Table 7 below.

\section{TABLE 7: AEDB LOI MILESTONE SCHEDULE}

\begin{tabular}{|c|c|}
\hline Milestones & Time Frame (in Months) \\
\hline Issuance of Letter of Intent (LOI) & To \\
\hline $\begin{array}{l}\text { Submission of complete feasibility study to AEDB, comprisinc } \\
\text { (i) Technical study including resource assessment, plant and } \\
\text { equipment details, layout and energy production analysis. } \\
\text { (ii) Grid Interconnection Study (approved by NTDC) } \\
\text { (iii) EIA / IEE study (approved by provincial Environmental } \\
\text { Protection Agency) }\end{array}$ & No later than ten (10) months after issuance of LOI \\
\hline $\begin{array}{l}\text { Vetting and approval of feasibility study by AEDB (including } \\
\text { verification of production estimates through third party } \\
\text { consultant, if required, cost of which shall be borne by the } \\
\text { Sponsor(s)) }\end{array}$ & $\begin{array}{l}\text { Within two (2) months after submission to AEDB. (provided any } \\
\text { requisite modifications are timely made by the Sponsor(s) and } \\
\text { the modified feasibility study is resubmitted within } 15 \text { days of a } \\
\text { letter by AEDB requiring the modifications) }\end{array}$ \\
\hline Tariff and Generation License from NEPRA & Within four (4) months of approval of feasibility study by AEDB \\
\hline Acceptance of Tariff by IPP & Within fifteen (15) days of determination of tariff by NEPRA \\
\hline $\begin{array}{l}\text { Posting of Performance Guarantee for Issuance of Letter of } \\
\text { Support (LOS) }\end{array}$ & Within fifteen (15) day of acceptance of Tariff by IPP \\
\hline Issuance of Letter of Support (LOS) by AEDB & Within fifteen (15) days of posting of Performance Guarantee (PG) \\
\hline
\end{tabular}

In case the developer fails to meet the LOI Milestones or perform any other obligations set forth in the Policy and this LOI, including the extension of the date of expiry of the bank guarantee as provided herein, the AEDB will terminate this LOI and encash the bank guarantee.

Provided the developer meets the LOI Milestones on the stated dates, the Expiry Date of the LOI shall be extended on a day-for-day basis for the number of days of delay by which the approval or review by the relevant public sector entity listed in the LOI Milestones is delayed beyond the corresponding period stated in the LOI Milestones.

\subsubsection{LAND ACQUISITION}

Developers are encouraged to have started the land identification and land acquisition process prior to the LOI stage. However, at the LOI stage, a process of acquisition of the exact plot will need to have begun. At the very least, developers must have acquired access to the land order to carry out the feasibility study required pursuant to the LOI. As mentioned above, solar project developers interested in developing solar power in Pakistan have two options to secure land: through direct negotiations with landowners or through the support of provincial governments and as the majority of activity for solar developers is in Punjab and Sindh, their procedures for land acquisition are dealt with in detail in this section.

\section{Support of provincial governments to obtain public lands}

\section{PUNJAB}

In the early stages of development of the solar power market in Pakistan, the Government of Punjab allocated a large parcel of land for the 1000 MW Quaid-e-Azam Solar Park, located in the Bahawalpur region of Punjab province. Quaid-e-Azam Solar Power Private Limited, a company wholly owned by the Government of Punjab, developed and commissioned a $100 \mathrm{MW}$ power plant. A Chinese company called Zonergy Ltd. is developing the remaining $900 \mathrm{MW}$ and has signed a power purchase agreement for $300 \mathrm{MW}$ under the 2015 tariff. 
The Government of Punjab issued a notification of a Statement of Conditions ${ }^{34}$ on 9 May, $2014^{35}$ specifying the criteria for land allocation and leasing for solar power projects, and has appointed a committee for recommending suitable lands available for lease under this notification. ${ }^{36}$ Under the notification, the Government may lease public lands for a project after advertising in at least two national daily newspapers. Companies wishing to lease public lands may apply to the Energy Department, complying with the following requirements:

- The company must have a valid LOI from the Punjab Power Development Board (PPDB) and/or the AEDB and is eligible to carry out a project feasibility study.

A completed application form must be submitted, as set out in Schedule 1 of the notification of conditions, accompanied by the company profile and the LOI. If the LOI has been issued by the AEDB, the company must provide all other documents submitted to the AEDB for issuance of the LOI

Within 30 days from receipt of application, the Energy Department may make a recommendation to the Government of Punjab to allocate land to the applicant or it may reject the application. Following such recommendation, the Government of Punjab shall direct the collector to allocate the land under an Allocation Letter ${ }^{37}$ for the period of the LOI and if an extension of the

LOI is granted, then the allocation may also be extended. If the LOI is cancelled, then the land allocation will also be cancelled. The collector is an officer appointed by the Board of Revenue in Punjab to review the land application. The company will be required to achieve the milestones as set out in the LOI. The Allocation Letter provided to a company shall authorize the company to carry out a Feasibility Study and other surveys. After acceptance of the Feasibility Study and issuance of the LOS by the PPDB and the AEDB, the company may apply for the lease of land through the Energy Department.

If the Energy Department is satisfied with the contents of

\footnotetext{
34 A Statement of Conditions is a notification issued under the Colonization \& Disposal of

Government Lands Act, 1912, as applicable in each province, which governs the grants of land for a specific designated purpose.

35 http://www.google.com.pk/url?sa=t\&rct=j\&q=\&esrc=s\&source=web\&cd=1\&ved=0CBoQFjAAahUKEwic46GqxvvIAhWLVhoKHcuhCac\&url=http\%3A\%2F\%2Fenergy.punjab.gov. pk\%2Fdownloads\%2FQASP_LANDALLOCATION_SOC_09122014.pdf\&usg=AFQjCNFf9d dqMKjtNPLJeKk6DeufbJDALQ\&bvm=bv.106923889,d.bGg

36 The committee is made up of members from the Energy Department, Finance Department, the Board of Revenue, Punjab Board of Trade and Investment, a nominee of the district concerned, including Cholistan Development Authority and the Managing Director of the Punjab Power Development Board.

37 A standard form of this Allocation Letter is attached to the Notification of Conditions.
}

the application, it shall forward the same to the committee to prepare the recommendation to the Government of Punjab to lease the land to the applicant. After the recommendations of the committee, the collector may, subject to the control of the Punjab Board of Revenue, allot land to the company and execute the lease agreement with the company as prescribed by the Government for the period of the Generation License plus six months, subject to receiving the advance payment of the lease money. The rent payable under such lease is decided by the Government of Punjab, according to prevailing market conditions. To incentivize solar power projects, the current lease rate for public lands in Punjab is US \$1 per acre per year. The lease agreement is effective at financial close. ${ }^{38}$

If the project developers identify public lands, they may approach the provincial government to have that land allocated to them. However, that piece of land still needs to be advertised and the PPDB has discretion to award it to someone else after advertisement.

\section{SINDH}

Sponsors and/or project companies looking to set up solar power plants in Sindh have primarily acquired public land directly from the Government of Sindh under the Government of Sindh land grants policy. Sindh has identified a potential 42,000 hectares of land that they grant on a first come, first served basis. If the developers identifies public land themselves, the Government of Sindh will assist the developers with obtaining that land under the land grants policy. Unlike Punjab, this land does not have to be publically advertised.

The land grants policy is administered pursuant to a Statement of Conditions issued by the Government of Sindh on 11th June 2015. ${ }^{39}$ Under this statement, the Government of Sindh may grant a lease for 30 years (renewable for a further period of 30 years) for the development of renewable energy power projects to a company, person or group of persons. The Government of Sindh has absolute discretion in its selection of grantees. The land granted is required to be leased at the market price provided that no land is allowed to be leased at rates lower than US \$28, US \$47 and US \$76/acre/ year for first 10 years, 11 - 20 years and 21 - 30 years,

\footnotetext{
38 The Notification of Conditions is ambiguous with regard to when the lease is executed. 39 Government of Sindh has notified Statement of Conditions No.01-32-2015/SO-VI/354/15 on 11th June 2015 for grant of land for the purpose of producing energy from renewable resources including solar energy. A copy of this statement is contained at Annex 7
} 
respectively. ${ }^{40}$ The market price of the land to be granted is proposed by the Collector, ${ }^{41}$ who is an officer appointed by the Sindh Board of Revenue. The Collector must take into consideration prices of land transferred during the last 12 months, the valuation table notified by the Sindh Board of Revenue under the Stamp Act 1899 for the purpose of levying a stamp tax and any other modes as deemed fit to provide a fair basis for assessment. The market price proposed by the Collector is then considered and decided by a scrutiny committee.

An application for the grant of land is made through the 'one-window' facility for renewable projects established in the Energy Department, Government of Sindh. The application is then reviewed and forwarded by the Energy Department to the Land Utilization Department with a copy of a valid LOI and the observations and recommendations of the Energy Department. The Land Utilization Department, Government of Sindh, after considering the observations of the Energy Department, may call for the report from the Collector regarding the availability of land, site plan and market price. This report is taken to the scrutiny committee, which is made up of senior members of the Sindh Board of Revenue, Land Utilization Department, Energy Department, Finance Department, commissioner of the concerned division and the Collector. The committee verifies all the documents received by it and formulates its recommendation for the Government of Sindh. Once the Government approves the lease, a lease deed is executed upon payment of the lease money for the first 10 years. The rents due during the following 10-year periods are paid three months prior to expiry of the then-current 10 -year period. The lease is executed prior to financial close.

The lease is granted subject to various conditions, including requiring the lessee to contribute to the improvement of the livelihoods of the local population and maintaining a preference for hiring locals for semi-skilled and unskilled jobs. An annual report must be given to the Government of Sindh regarding the provision of jobs to locals. Furthermore, a transfer of any interest in the land is not permitted without prior approval of the Government. ${ }^{42}$

\footnotetext{
40 Exact market rates are difficult to come by but are in the range of US $\$ 1000$ to US $\$ 4000$ per acre per year.

41 Sindh Land Revenue Act 1967.

42 Security interests may be created in favour of lenders upon recommendation of the energy department
}

Land must be registered with the local registrar of the relevant area. Developers should note that this was difficult for wind transactions in the wind corridor but it may not be as big concern for other areas even in the rest of Sindh. The registration costs are ad valorem of the land price.

\section{SUPPORT OF PROVINCIAL GOVERNMENTS TO OBTAIN PRIVATE LANDS}

The provincial government can also support private developers in obtaining private lands. Lands can be obtained pursuant to the Land Acquisition Act 1894. Under this act, the developer can ask the government to acquire land for them through the procedures set out in the act. In this circumstance, the government would acquire the land on behalf of the developer. In reality in Pakistan, developers are encouraged to negotiate directly with the landowners rather than going through the provincial government.

\section{DIRECT NEGOTIATION OF PRIVATE LANDS}

If developers have not received a grant/lease of public land, the AEDB encourages developers to purchase land directly themselves. The AEDB has worked with NTDC to identify sites in provinces throughout Pakistan. Developers are advised to contact the AEDB directly about these sites. See Section 6.1.2 above for more information on this.

\subsubsection{FEASIBILITY AND GRID INTERCONNECTION FEASIBILITY}

Under the LOI a Feasibility Study must be carried out within 10 months of the issuance of the LOI. The feasibility study must include, inter alia, solar PV plant equipment siting details, detailed power production estimates based on solar irradiance data of the project site, soil test reports, technical details pertaining to solar PV panels and other allied equipment to be used in the solar PV plant, grid tied solar PV project, electrical studies (including but not limited to a short-circuit study, power quality study, load flow study and stability study), environmental study, project costing, financing plan, carbon credits, financing terms, tariff calculations and assumptions for financial calculations including economic/financial analysis. The developer is also advised to liaise with the power purchaser while determining the site, project layout, sub-station design and layout, the transmission line, interconnection arrangements, and other related matters. 


\section{GRID INTERCONNECTION STUDY}

In order to apply for the Solar FIT from NEPRA, approval from NTDC or the DISCO is required for the grid interconnection of the project. In order to obtain this approval, a grid interconnection study is required. This will need to be prepared by local consultants. Various local consultants are available to assist and will support the entire grid connection approval process. The study must include simulation studies to the effect that solar-based power will be evacuated to the grid in accordance with the project timeline and must include that the power injected to the grid will not have any adverse effect on the national grid as required under the Grid Code. After submitting a Grid Interconnection Study, the developer must obtain approval by NTDC or the relevant DISCO for grid connectivity. Such approval must also conclude that the power injected to the grid by the project will not have any adverse effect on the national grid as required under the Grid Code (timeframe estimated to secure approval of grid interconnection from NTDC is estimated to be two weeks however in practice this may take two to three months following an iterative process of reviews of the interconnection proposal and related studies). Contact information for NTDC and seeking approval of the Grid Interconnection Study:

National Transmission \& Despatch Company Limited

Room \# 414, WAPDA House Shahrah-e-Quaid-e-Azam, Lahore - Pakistan.

Tel: 92 (042) 9202229

Fax:92 (042) 9200894

The fee for application for grid connection approval is a flat fee of US $\$ 1,746$ regardless of project size and payable to NTDC upon submission. Under the 2006 RE Policy, NTDC is required to provide grid interconnection but approvals can take time as grid interconnection is complex and costly especially in remote areas. It is recommended that NTDC is approached as soon as possible and that developers work with them to identify areas that are most suitable for evacuation of power.

\subsubsection{NEPRA FIT APPLICATION AND GENERATION LICENSE APPLICATION}

Within four months of the approval of the Feasibility Study by the AEDB, the developers must have opted (or officially applied) for the FIT. The purpose of this application process is to secure approval of the FIT for the project and grid connectivity from NEPRA and the relevant off-taker: i) NTDC; or ii) the relevant local distribution company (DISCO).

The suggested time period of approval/grant of the tariff is 10 working days as per the NEPRA Upfront Tariff Regulations 2011. However, delays may occur especially if inadequate project-related information is available, and developers are encouraged to start the overall process as early as possible.

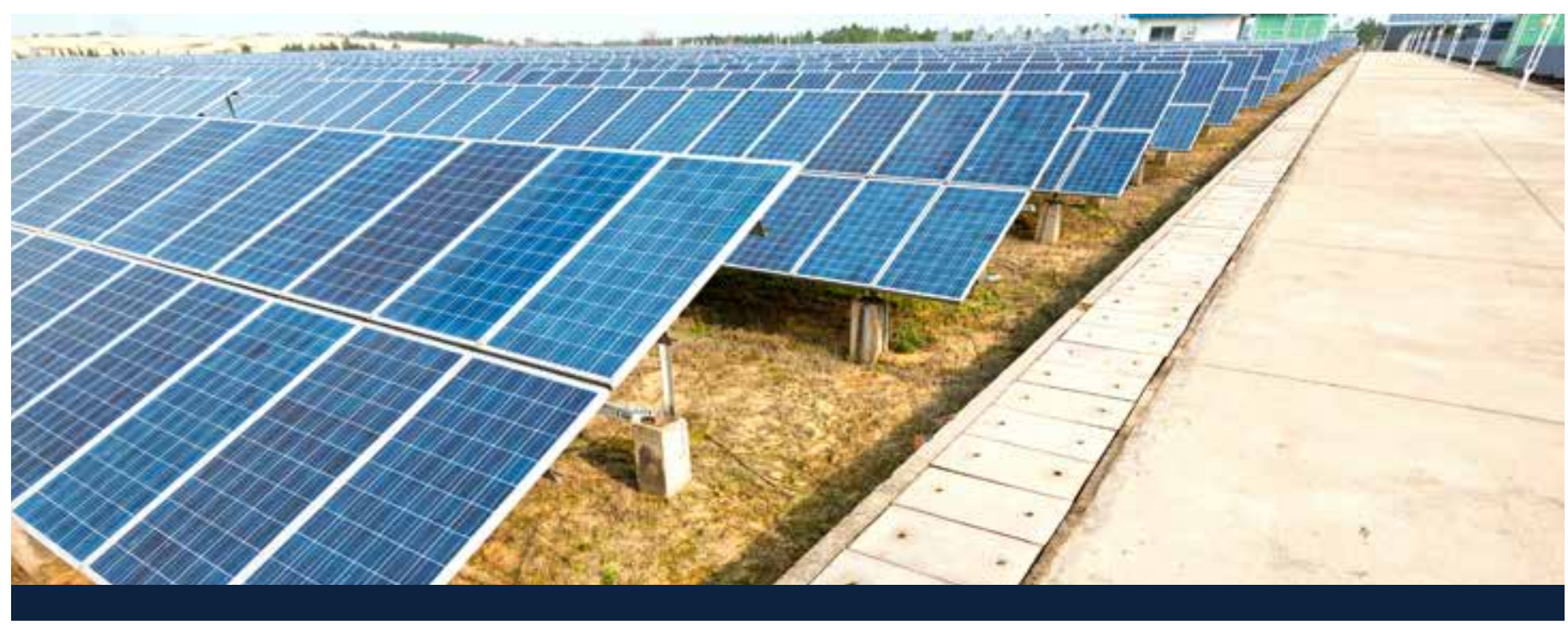


In order to apply for the FIT, the NEPRA Upfront Tariff Regulations, 2011 are applicable and require application as per Section 4 of this regulation. The major requirements to apply or "opt" for the FIT are:

1. Projects must hold a valid Letter of Intent (LOI) from the AEDB or the relevant provincial government agencies;

2. Developer must provide a description of proposed generation facility and site

3. Copy of Generation License or application of the same must be submitted to NEPRA: A power company must obtain a generation license from NEPRA in order to set up a power plant. NEPRA's Licensing (Application \& Modification Procedure) Regulations, 1999 outlines the procedure and requirements in order to obtain a license for generation, distribution or transmission business in Pakistan. To apply for a generation license, the following are the major requirements by the regulator for the license application:

- Application processing fee. This fee is indexed with the CPI of Pakistan and outlined in Table 8 below

- Certified copies of company incorporation and latest filed annual tax return.

- Detailed profile of experience of applicant including its management staff and its members in the electricity industry.

- CVs of senior management, technical and professional staff.

- Evidence of sufficient financial and technical resources backed by audited financial statements, profile of technical staff and sub-contractors, etc.

- Type, technology, model, technical details and design of the facilities proposed to be acquired, constructed, developed or installed.

- In case of a license for a new facility or system, a feasibility study of the project covering details such as technology, type or model of equipment, and design details, as well as the expected life of the facility.
TABLE 8: GENERATION LICENSE FEE APPLICATION

NEPRA Fee for Generation License Application

\begin{tabular}{|l|l|}
\hline Size of Plant & Fees (US \$) ${ }^{43}$ \\
\hline Up to $1 \mathrm{MW}$ & 384 \\
\hline > 1 MW up to 10 MW & 768 \\
\hline > 10 MW up to $20 \mathrm{MW}$ & 1,151 \\
\hline > $20 \mathrm{MW}$ up to $50 \mathrm{MW}$ & 1,535 \\
\hline > 50 MW up to 100 MW & 1,919 \\
\hline Above 100 MW & 3,838 \\
\hline
\end{tabular}

The complete application process for obtaining a generation license is detailed in the NEPRA Licensing Regulation, 1999, including a number of amendments. The timeframe to obtain a Generation License in Pakistan is approximately $4-8$ weeks.

4. Company incorporation documents and other related documents. By this stage, once the developer has decided to set up an IPP in Pakistan it shall set up its Special Purpose Vehicle company, registered in Pakistan, according to the Pakistan Companies Ordinance $1984^{44}$. This is also indicated in the 2006 RE Policy (Section 8.9.2). Setting up an SPV company takes about a month and there are company registration offices in each province. However, it is advised to start the process at an earlier stage if there are non-national directors as they can take some time to be cleared by the Pakistan Securities and Exchange Commission (SECP). ${ }^{45}$

5. Affidavit (typically submitted by a local law firm per the laws of Pakistan) stating that the proposed plant equipment and machinery is/will be new as per project planning and design.

6. Approval by NTDC or the relevant DISCO for grid connectivity. See sub-section 6.2.2 above.

7. Nonrefundable application fee (in addition to the Generation License Fee). Application processing fees are detailed in Table 9 below. ${ }^{46}$

43 The exchange rate used for the purpose of this guidebook is PKR 105/ US 44 The exchange rate used for the purpose of this guidebook is PKR 105/ US\$ 45 There are various generic guidelines on the SECP website (http://www.secp.gov.pk/CLD/ cld_guides.asp) and some specific ones (http://www.secp.gov.pk/Guides/PromotersGuideinEnglishdec022010.pdf) but please note that they may be outdated.

46 NEPRA application and processing fees are indexed with the CPI and subject to marginal changes. The reference is based on the September 2008 CPI. 
TABLE 9: NEPRA UPFRONTTARIFF APPLICATION FEE

\begin{tabular}{|c|c|}
\hline \multicolumn{2}{|c|}{ NEPRA Fee for Application of Upfront Tariff } \\
\hline Size of Plant & Fees (US \$) \\
\hline Up to 1 MW & 192 \\
\hline > 1 MW up to 10 MW & 479 \\
\hline > 10 MW up to 100 MW & 960 \\
\hline Above 100 MW & 1,919 \\
\hline
\end{tabular}

Once the developers apply for the FIT, they cannot apply for a cost-plus tariff and may risk losing any guarantees or payments unless otherwise agreed to with the authorities. Therefore, developers should determine their appetite for risk and any associated project risks before applying for a FIT.

The FIT application in triplicate should be filed to Registrar NEPRA at following address:

The Registrar - National Electric Power Regulatory Authority

NEPRA Tower Attaturk Avenue (East), Sector G-5/1, Islamabad - Pakistan.

Email : registrar@nepra.org.pk

Tel: +92 519206500

Fax: +92512600021

Developers should note that the decision to opt for the upfront tariff once exercised is irrevocable.

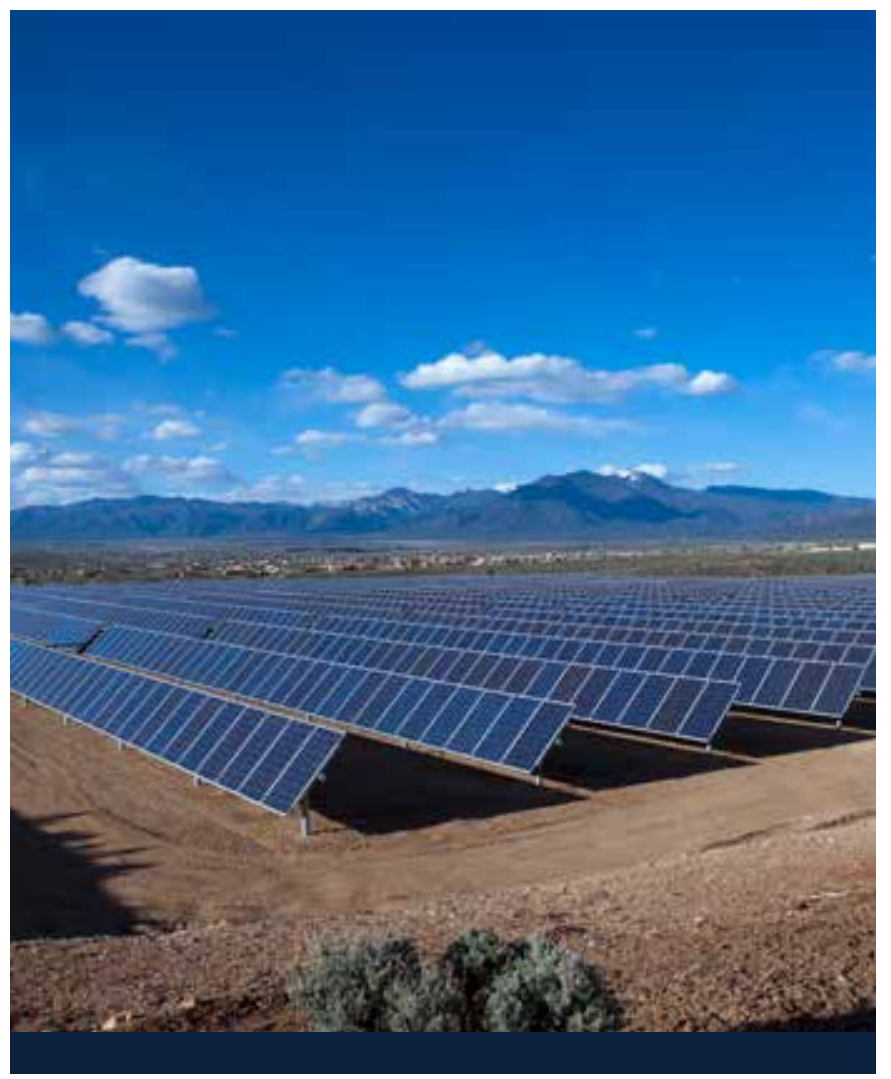

\subsubsection{ENVIRONMENTAL ASSESSMENT}

All solar projects will require environmental approval from the provincial Environmental Protection Agency (EPA) offices. This is required within 10 months of the issuance of the LOI. In order to get EPA approval, developers must prepare:

- An Initial Environmental Examination (IEE) if the project is under $200 \mathrm{MW}$; or

- An Environmental Impact Assessment (EIA) if the project is greater than $200 \mathrm{MW}$.

The process for obtaining these is detailed in the Review of IEE and EIA Regulations 2000. ${ }^{47}$ Developers usually hire local consultants to carry this out and the process takes about two to four months. The two main concerns that the EPA has with regard to solar projects are water requirements and disposal of environmental waste. The IEE and EIA are submitted with the application form and review fees. ${ }^{48}$ Environmental approval is given subject to ongoing monitoring and compliance with conditions or recommendations raised in the IEE or EIA.

Contacts for Sindh and Punjab Environmental Projection Agencies:

The Secretary

Environment and Alternative Energy Department

Government of Sindh

Plot No ST/2/1, Sector 23, Korangi Industrial Area Karachi.

Punjab Director (EIA)

Mr. Nasim-ur- Rehman Shah

Telephone:

Email: dir.eia@punjab.gov.pk

\section{OTHER ENVIRONMENTAL CONSIDERATIONS}

Developers should note that in order to deliver a project that is acceptable to international lending institutions (i.e. to enable financing to be provided), work should be carried out in accordance with the additional requirements of the key standards and principles, such as the Equator Principles, IFC Performance Standards and World Bank Health and Safety Guidelines. Further details on these are contained in Annex 6.

47 http://epd.punjab.gov.pk/system/files/REVIEW\%20OF\%20IEE\%20AND\%20EIA\%20REGULATIONS\%2C\%202000.doc.pdf

48 The application form is standard and the review fees vary from US $\$ 140$ to US $\$ 280$ depending on the size of the project. 


\subsubsection{LETTER OF SUPPORT AND PERFORMANCE GUARANTEE}

The developer applies for an LOS once they have the following prerequisites

- Generation License;

- Tariff Determination from NEPRA; and

- Posted a performance guarantee.

\section{PERFORMANCE GUARANTEE}

They developer must post a performance guarantee within 15 days of the NEPRA approval of their tariff application in order to secure the LOS. The Performance Guarantee $(\mathrm{PG})$ is US $\$ 2,500 / \mathrm{MW}$ and should be in excess of 15 months (3 months longer than the LOS term, which is 12 months). The terms that govern the return/amendment/ encashment of the PG are detailed below (Termination of the LOS).

\section{LOS}

The LOS is signed by the main project sponsor and the AEDB. If the LOI has been issued by a provincial agency, the provincial agency also signs the LOS. The project is then governed by the LOS along with the EPA and IA (together the LOS Project Agreements). The LOS takes precedence over the EPA and IA in case of any conflict. The LOS will be issued by the AEDB within seven days of the posting of the PG, provided the developer has a generation license. A sample LOS can be found at the AEDB website ${ }^{49}$ and is contained in Annex 4 of this document.

\section{FEES}

Non-refundable processing fees of up to US $\$ 100,000$ for projects above $50 \mathrm{MW}$, US\$ 50,000 for projects from 6 $50 \mathrm{MW}$ and US\$20,000 for projects from $1-5 \mathrm{MW}$ shall be charged at the time of signing the LOS. These must be paid within one month of signing the LOS.

\section{TERM OF THE LOS}

The validity of the LOS is the earlier of (i) achievement of financial close or (ii) one year from the date of determination by NEPRA, called the Required Financial Closing Date (RFCD). If the AEDB determines that any delay by the project company in achieving financial close by the RFCD is due to events beyond the reasonable control of the project company or that financial close can be achieved shortly, the AEDB shall be entitled to grant in writing to the project company a one-time extension of up to a maximum period of six months beyond the RFCD.

This extension will only be granted if:

- NEPRA consent is obtained;

- The PG is extended by a further six months; and

- The PG maximum value is doubled.

NEPRA consent is not required and there is an automatic extension if consent for currency convertibility from the State Bank of Pakistan (SBP) has not been obtained. The developer is automatically given more time to obtain this by the AEDB.

If financial close is not reached by the RFCD (or any extension thereto), the PG will be encashed in full by the AEDB. If the delay is caused by the actions of the GOP, the AEDB or the Purchaser, then the Project Company shall not be penalized.

\section{TERMINATION OF THE LOS}

The Project Company will have the option to terminate the LOS and all or any of the the Project Agreements executed by the counterparties thereto at any time before the RFCD. Such termination option may only be exercised upon payment by the Project Company to the AEDB of a Termination Amount equal to (i) the maximum amount in which the PG can be encashed multiplied by the number of months from the date of issuance of this LOS to the date of receipt by the AEDB of the Termination Amount divided by the total number of months from the date of issuance of the LOS to the RFCD, and (ii) the AEDB's receipt of the processing fee in full.

In the event of termination of the LOS and/or the Project Agreements by the Project Company without payment of the Termination Amount, the AEDB shall be entitled to encash the PG. To avoid any confusion, in the event that the Project Company exercises the termination option during the additional period provided to achieve Financial Close, the entire doubled amount of the PG shall be encashable on call by the AEDB.If financial close is reached by the RFCD (or by the date of any extension granted), the $\mathrm{PG}$ is returned to the developer. 


\subsection{Stage 3: LOS to Financial Close}

Once the FIT is granted to a project, the developers have to achieve the financial close within one year unless an extension is granted by the AEDB under the LOS as described in Section 6.2.5 above.

\subsubsection{ENERGY PURCHASE AGREEMENT}

The key project documents and agreements under the FIT regime are the Energy Purchase Agreement and the Implementation Agreement, which can be found on the AEDB website..$^{50}$ It is important to note that the basic terms of these project documents have been used in Pakistan for IPP projects for the last 20 years. The security package and sovereign guarantee offered has been banked by international investors and lenders numerous times in the past.

- Energy Purchase Agreement $(\mathrm{EPA})^{51}$

\begin{tabular}{|c|c|}
\hline Term & 25 years (unless extended by a Force Majeure Event) \\
\hline Parties & $\begin{array}{l}\text { The EPA is signed by the Project Company (the Seller) and the Power Purchaser (DISCO or CPPA). The EPA is } \\
\text { directly negotiated with the Power Purchaser, which could be the CPPA as a central off-taker, or a DISCO, which } \\
\text { is a distribution company in the respective geography of project location. }\end{array}$ \\
\hline Take or Pay & $\begin{array}{l}\text { The EPA is a take or pay agreement. The Seller is paid for all net electrical output delivered, as measured by } \\
\text { the meter. Payments are made for net electrical output that would have been delivered but for curtailment or } \\
\text { specific dispatch instructions (i.e. deemed output). }\end{array}$ \\
\hline Contract Capacity & $\begin{array}{l}\text { The Seller must state its Contract Capacity in MWp DC. The Seller may, where necessitated by unforeseen } \\
\text { circumstances, reduce the installed capacity before the Commercial Operations Date by a maximum margin of } \\
\% 10 \text { of the Contract Capacity. }\end{array}$ \\
\hline $\begin{array}{l}\text { Required Commercial } \\
\text { Operations Date }\end{array}$ & $\begin{array}{l}\text { This is negotiated by the Seller with the AEDB with the following limitations: } 8 \text { to } 12 \text { months for } 1 \text { to } 20 \mathrm{MW}, 10 \text { to } \\
18 \text { months for }+20 \text { to } 50 \mathrm{MW}, 12 \text { to } 18 \text { months for }+50 \text { to } 100 \mathrm{MW} .{ }^{52}\end{array}$ \\
\hline Letter of Credit & $\begin{array}{l}\text { A Letter of Credit (LOC) in the amount of US } 35 \$ \text { per } \mathrm{kW} \text { of the Contract Capacity must be delivered to the } \\
\text { Power Purchaser prior to Financial Close. The LOC must be maintained in full force and effect and will not } \\
\text { be returned to the Power Purchaser until COD (unless terminated prior to COD, in which case the LOC must } \\
\text { be maintained until } 30 \text { days after such termination). The LOC may be drawn on if the Seller has not paid the } \\
\text { liquidated damages prior to COD, as set out in the Liquidated Damages (LD) section below. } \\
\text { The LOC may also be encashed in full if there is a Seller Event of Default prior to COD. }\end{array}$ \\
\hline Liquidated Damages & $\begin{array}{l}\text { Liquid Damages (LDS) apply if: } \\
\text { - Contract Capacity is reduced by between \%5 and \%10. LDs are payable in an amount equal to 350,000\$ } \\
\text { multiplied by the number of MW (prorated for any fraction thereof) if the Contract Capacity is reduced by } \\
\text { between \%5 and \%10. } \\
\text { - Failure to achieve COD by Required COD. Here, the Seller shall pay the Purchaser as LDs an amount equal to } \\
\text { US } 2.50 \$ \text { per kW of the Contract Capacity for each Month (prorated Daily) thereafter until the COD is actually } \\
\text { achieved. } \\
\text { - EPA is terminated prior to COD for a Seller Event of Default. In this scenario, the Seller shall reimburse the } \\
\text { Purchaser for all costs and expenses (including reasonable attorneys' fees) relating to the Project incurred by } \\
\text { the Purchaser prior to such termination, which amount in any event shall not exceed the Rupee equivalent of } \\
\text { one hundred and fifty thousand Dollars (US 150,0oo\$). } \\
\text { - Liquidated Damages for Shortfall Energy. The Seller is required to pay LDs to the Purchaser if their annual } \\
\text { electrical output falls below the benchmark annual electrical output (based on the benchmark capacity factors } \\
\text { provided in the tariff). This is known as Shortfall Energy. To calculate Shortfall Energy, the Seller may take into } \\
\text { account any surplus energy produced in previous years as credit energy. The LDs are calculated as the kilowatt } \\
\text { hours representing the positive balance of the Shortfall Energy and the then-prevailing use of system charge } \\
\text { per kWh allowed by NEPRA to the Purchaser for interconnection to and use of its grid system. }\end{array}$ \\
\hline
\end{tabular}

50 http://www.aedb.org/index.php/ju-elibrary/elib-solar/solar-standard-docs

51 Capitalized terms not defined here will be defined in the standard EPA available on the AEDB website

52 NEPRA had previously determined that the construction period was 8, 10 and 12 months fro projects of 1-20 MW, 20 to $50 \mathrm{MW}$ and 50 to $100 \mathrm{MW}$ respectively. However, these longer periods are provided in the EPA to accommodate NTDC's concern regarding the proximity and availability of the Grid, given the requirement for it to complete the project interconnection works $60-90$ Days before the Commissioning Tests That would have left only 5-9 months if the construction period stipulated in NEPRA's Tariff Determination is strictly followed (which was not the intent of NEPRA). 


\section{Operations and} Maintenance Fund
Pass-Through Items and Supplementary Tariff
The developer must maintain an operations and maintenance (O\&M) fund. The Reserve Fund shall be funded by the Seller out of retained earnings commencing on the date that the first Energy Payment is received. On the date of each Energy Payment receipt, one thirty-sixth (36/1th) of the annual O\&M budget for the Complex will be deposited into the Reserve Fund until a reserve equal to nine such deposits has been established.

The Reserve Fund is to ensure that the developer has sufficient funds available for major maintenance expenses. "Major Maintenance Expenses" means expenses for an item of maintenance or repair of the Complex which would require substantial expenditure and which is anticipated to be performed in accordance with the manufacturers' determinations, sound engineering practices or Prudent Utility Practices, but which is not expected to be performed on a recurring basis. The developer can draw on the Reserve Fund only to the extent it lacks other funds available for paying maintenance and associated operating expenses with respect to the facility, or to pay for alterations, repairs, improvements, renewals and replacements necessary for the proper operation of the facility. It has to replenish if and when it uses such expenses.

This Reserve Fund is not required if the developer has entered into a Long-Term Major Maintenance Services Agreement with a reputable O\&M contractor

The Purchaser shall pay the Seller, any amount for the Pass-Through Items evidenced in accordance with the EPA. Pass-Through items are contained in Schedule 1 to the EPA and are standard and set out below.

(a) Payments by the Seller into the Workers' Welfare Fund and the Workers' Profit Participation Fund53 for its employees required to be paid in relation to the Project pursuant to the Laws of Pakistan;

Sales tax, excise duty or any other taxes, duties, levies, charges, surcharges, or other governmental impositions (including without limitation export tax, octroi, rawangimahsool etc.) wherever and whenever payable on the generation, sale, exportation or supply of electricity or electricity generating capacity by the Seller during the Term, provided that the Seller has not been previously compensated fully for any such item by the Purchaser or by the GOP;

(b) Sales tax, excise duty or any other taxes, duties, levies, charges, surcharges, or other governmental impositions (including without limitation export tax, octroi, rawangimahsool etc.) wherever and whenever payable on the generation, sale, exportation or supply of electricity or electricity generating capacity by the Seller during the Term, provided that the Seller has not been previously compensated fully for any such item by the Purchaser or by the GOP;

(c) The cost of the Metering System if not procured by the Purchaser;

(e) Any upgrade to the protective devices of the Complex required by the Power Purchaser; and

(f) The cost of the DPLC or Fiber Optic System including OPGW/ADSS, SDH/PDH unit along with all the related in-door and out-door equipment, as provided in Section 7.7(a)(iii) of the Energy Purchase Agreement.

Each invoice for the Pass-Through Items delivered to the Purchaser must be accompanied by the original invoices or payment receipts for which the Seller seeks recovery from the Purchaser.

A supplementary tariff is permitted when:

- There is a change in law resulting in a material change in cost or revenue. Any modifications or expenditures required to comply with the change in law are reimbursed through a supplemental tariff.

- If the plant is restored, the cost is permitted as a supplemental tariff.

Purchaser Delayed

There is compensation payable by the Purchaser if there is a delay in commissioning caused by the Purchaser.

Commissioning
The Purchaser shall pay to the Seller monthly, in arrears, the interest component of the tariff plus $\% 50$ of the O\&M Component and \%50 of the Insurance Component multiplied by the Average Daily Energy for each Day during the period of such delay.

If the delay continues for 60 days, the Purchaser is required to pay the debt when it falls due. If commissioning subsequently occurs, the payments made by the Purchaser to service any principal debt shall be recovered together with interest at KIBOR plus \%3.5 per annum (on the monthly outstanding balance of such amounts) commencing on the date of such payments by the Purchaser and ending on the date of complete repayment thereof by the Seller through successive deductions of the ROE Component from the monthly Energy Payments until such amounts have been completely recovered. 


\begin{tabular}{|c|c|}
\hline Term & 25 years (unless extended by a Force Majeure Event) \\
\hline Purchaser Step-In & $\begin{array}{l}\text { If, after COD, and without the prior written consent of the Purchaser, the Seller ceases to operate the plant for a } \\
\text { period of } 30 \text { consecutive days other than because of: } \\
\text { (i) a Force Majeure Event, } \\
\text { (ii) a Scheduled Outage or a Maintenance Outage, } \\
\text { (iii) a Forced Outage or a Partial Forced Outage, } \\
\text { (iv) a Non-Project Event, or } \\
\text { (v) any act or omission of the Purchaser and/or the Grid System Operator that effectively prevents the Seller or } \\
\text { its Contractors from operating the Complex, then the purchaser is entitled to step-in and operate the project } \\
\text { until the the Seller demonstrates, to the reasonable satisfaction of the Purchaser, that the Seller can and will } \\
\text { resume normal operation of the Complex or until the Lenders shall have exercised their rights in accordance } \\
\text { with the Financing Documents, including the Lender's Direct Agreement, to enter the Complex and operate it. } \\
\text { The Purchaser is obliged to pay to the Seller the Debt Principal Repayment Component and the Interest Charges } \\
\text { Component of the applicable Energy Price multiplied by the Average Daily Energy during such period. }\end{array}$ \\
\hline Force Majeure & $\begin{array}{l}\text { There are a number of Force Majeure events outlined in the agreement:• Any event beyond reasonable control } \\
\text { of either Seller or Purchaser, including an Act of God } \\
\text { - Natural Causes } \\
\text { - Strikes } \\
\text { - Lapse of Consents } \\
\text { - Change in Law } \\
\text { - Pakistan Political Event ("PPE") } \\
\text { If there is a force majeure event that results in material damage/material modification greater than the } \\
\text { threshold amount, the Seller will be compensated for restoration less any insurance proceeds and less the } \\
\text { threshold amount. The costs will be reimbursed via an increase in the tariff. }\end{array}$ \\
\hline Event of Default & $\begin{array}{l}\text { Mutual Events of Default } \\
\text { - Failure to pay within } 35 \text { days notice } \\
\text { - Material Misrepresentation } \\
\text { - Material Breach not remedied within } 30 \text { days } \\
\text { - Tampering of meters on three or more occasions } \\
\text { Seller Events of Default } \\
\text { - Construction Date greater than } 90 \text { days after Financial Close } \\
\text { - COD greater than } 365 \text { days after required COD } \\
\text { - After construction start date, failure to prosecute project in a diligent manner for } 30 \text { days } \\
\text { - Abandonment for } 30 \text { days (subject to carve outs) } \\
\text { - Failure to maintain Seller LOC } \\
\text { - Output less than \%6o of capable capacity over any year (subject to carve outs) } \\
\text { - Breach of share transfer restrictions } \\
\text { - Insolvency } \\
\text { - Irrevocable revocation of generation license } \\
\text { - Funder step in and failure to transfer to a third party within } 240 \text { days. } \\
\text { - Material breach of Implementation Agreement resulting in termination } \\
\text { - Termination of a site lease or loss of rights to own or operate the facility } \\
\text { - Delay of interconnection by more than } 155 \text { days beyond required COD } \\
\text { - Material breach of Implementation Agreement or Guarantee by the Government not remedied within } 30 \text { days. } \\
\text { - } \text { - }\end{array}$ \\
\hline
\end{tabular}

54 Minimum threshold amount is greater than (a) $\$ 5,000 / \mathrm{MW}$ or $\$ 100,000$ for a single event or (b) greater than $\$ 20,000 / \mathrm{MW}$ or $\$ 250,000$ aggregate in a year. 


\begin{tabular}{|l|l|}
\hline \multicolumn{1}{|c|}{ Term } & \multicolumn{1}{|c|}{25 years (unless extended by a Force Majeure Event) } \\
\hline Lender Step-In & $\begin{array}{l}\text { The Purchaser shall not terminate the agreement without giving notice to the Lenders. The Lenders have the } \\
\text { cure periods set out above which begin from the moment such notice is delivered to the Lenders. An election } \\
\text { notice can be given by the Lenders to extend the cure period by } 180 \text { days and the Seller's right to terminate is } \\
\text { suspended so long as the Lenders are diligently attempting to cure or mitigate or procure the cure or mitigation } \\
\text { of such Seller Event of Default or are pursuing the enforcement of their rights and remedies under the Financing } \\
\text { Documents against the Seller. A separate direct agreement with the lender can also be negotiated by the Power } \\
\text { Purchaser. }\end{array}$ \\
\hline $\begin{array}{l}\text { Termination } \\
\text { Payments } \\
\text { than a Seller Event of Default, the Purchaser shall reimburse the Seller for all costs and expense (including } \\
\text { reasonable attorneys' fees) relating to the Project incurred by the Seller prior to such termination, which amount } \\
\text { in any event shall not exceed the Rupee equivalent of one hundred and fifty thousand Dollars (150,000\$). } \\
\text { For termination payments that may arise under the EPA in favor of the Purchaser prior to COD, please see the } \\
\text { LOC section above. } \\
\text { All other termination payments are provided for in the IA. }\end{array}$ \\
$\begin{array}{l}\text { On a yearly basis, the annual electrical output of the generator is calculated based on the benchmark capacity } \\
\text { factors (\%17 for North and \%18 for the South in } 2016 \text { tariff). If annual electrical output is in excess of this, a } \\
\text { reduced tariff may apply as per the relevant NEPRA tariff determination. See Section 5.3 for more details on this } \\
\text { in relation to 2016 tariff. }\end{array}$ \\
\hline Excess Energy
\end{tabular}

\subsubsection{IMPLEMENTATION AGREEMENT (IA)}

The Implementation Agreement (IA) is the sovereign guarantee payment support mechanism provided by the Government of Pakistan. Key terms are set out below ${ }^{55}$

\begin{tabular}{|c|c|}
\hline Term & 25 years (unless extended by a Force Majeure Event) \\
\hline Parties & Project Company (the Seller) and GOP. It is negotiated by the AEDB on behalf of GOP. \\
\hline Term & The same term as the EPA. \\
\hline Title Protection & $\begin{array}{l}\text { If the Seller has leased land from the provincial government, GOP indemnifies the Seller from any losses arising in } \\
\text { connection with or relating to any defect in title that impedes or delays the project. }\end{array}$ \\
\hline $\begin{array}{l}\text { Taxation of the } \\
\text { Project Company }\end{array}$ & $\begin{array}{l}\text { During the Term, the Seller shall not be subject to taxation in Pakistan on its profits and gains derived from sale } \\
\text { of electricity under the Energy Purchase Agreement, including payments made by the GOP to the Seller under } \\
\text { Section } 15.1 \text { (Compensation upon Termination). Any change in this shall not give rise to a breach or default of } \\
\text { the GOP so long as such change results in a Change in Tax and can be treated as a Pass-Through Item under the } \\
\text { EPA. }\end{array}$ \\
\hline $\begin{array}{l}\text { Taxation of the } \\
\text { Investor }\end{array}$ & $\begin{array}{l}\text { Local investors will be taxed according to the laws of Pakistan and Foreign Investors will be taxed according } \\
\text { to the Bilateral Tax Treaty with their country. If no tax treaty exists, they are taxed according to the laws of } \\
\text { Pakistan. }\end{array}$ \\
\hline $\begin{array}{l}\text { Right to Import/ } \\
\text { Customs Duties }\end{array}$ & $\begin{array}{l}\text { The Seller and its Contractors shall be entitled to import without restriction and shall be exempt from (or } \\
\text { shall enjoy a reduced rate of) Customs Duty and Sales Tax on plant, machinery, equipment and spare parts, } \\
\text { and replacements required to be imported for the design, construction, completion, operation, repair and } \\
\text { maintenance of the solar plant }{ }^{56} \text { and any other item or items of plant, equipment or machinery that are } \\
\text { incorporated into the solar plant or whose use is dedicated to the operation and/or maintenance of the solar } \\
\text { plant approved by the AEDB and concurred to by the Federal Board of Revenue. Any charge in excess of that } \\
\text { which is law at the time of signing can be treated as a Pass-Through Item under the tariff. } \\
\text { Provided customs Duties and Sales Taxes are paid, all imported items will be cleared for release from customs } \\
\text { within } 15 \text { business days of arrival at the port of entry. } \\
\text { The agreement guarantees full currency convertibility provided the request is made } 15 \text { days in advance of } \\
\text { need. Consents from the State Bank of Pakistan to foreign currency accounts must be obtained. There are also } \\
\text { provisions on free transfer and repatriation of certain funds including equity. }\end{array}$ \\
\hline
\end{tabular}

55 Any capitalized terms in this section not defined in this document will be defined in the standard IA available on the AEDB website.

56 As provided in the Finance Act, 2014, the Fifth Schedule to the Customs Act, 1969 and the Sixth Schedule to the Sales Tax Act, 1990. See Section 8 for more details on taxes that apply, 


\begin{tabular}{|c|c|c|}
\hline Term & \multicolumn{2}{|c|}{25 years (unless extended by a Force Majeure Event) } \\
\hline Payment Guarantee & \multicolumn{2}{|c|}{$\begin{array}{l}\text { Schedule } 3 \text { of the IA contains the unconditional and irrevocable payment guarantee from the Government for } \\
\text { the payment obligations of the Purchaser under the EPA, which is entered into as a separate document. }\end{array}$} \\
\hline Force Majeure & \multicolumn{2}{|c|}{$\begin{array}{l}\text { There is compensation on termination for Force Majeure. The affected party is under an obligation to incur } \\
\text { reasonable sums of money to mitigate the effects of the Force Majeure. However, GOP will not be allowed to } \\
\text { claim relief of its obligations under the IA or the Payment Guarantee if there is a Political Force Majeure or a } \\
\text { Change in Law Force Majeure. }\end{array}$} \\
\hline $\begin{array}{l}\text { Restrictions on Share } \\
\text { Transfer }\end{array}$ & \multicolumn{2}{|c|}{$\begin{array}{l}\text { Under the IA, there are a number of lock-in periods for investors. The initial shareholder cannot reduce its } \\
\text { shareholding below \%51 prior to COD. The lead investor cannot reduce its shareholding below \%20 prior to COD. } \\
\text { Post COD, AEDB consent is required for any share transfer. However, the IA states that this will be granted } \\
\text { unless AEDB determines that such transfer is contrary to national security interest. }\end{array}$} \\
\hline Consents & \multicolumn{2}{|c|}{$\begin{array}{l}\text { The Implementation Agreement requires a number of consents from various government agencies, which must } \\
\text { be procured by the Seller prior to Financial Close. These include: } \\
\text { - State Bank of Pakistan consent to conduct transactions in foreign exchange; } \\
\text { - State Bank of Pakistan commitment to make available foreign currency if required; } \\
\text { - NEPRA consent to the Power Purchaser to off-take the electricity (required under the generations license); and } \\
\text { - Ministry of Commerce/Federal Board of Revenue import permits. } \\
\text { These consents are relatively straightforward to obtain. If there is a delay in obtaining these consents through no } \\
\text { fault of the Purchaser, an automatic extension of the LOS is given by the AEDB. }\end{array}$} \\
\hline $\begin{array}{l}\text { Compensation on } \\
\text { Termination }\end{array}$ & \multicolumn{2}{|c|}{$\begin{array}{l}\text { The IA contains compensation on termination of the EPA. The compensation varies depending on the } \\
\text { termination event. The key termination events and the compensation applied is outlined in the table below. Note } \\
\text { that the amount of debt, equity and ROE payable in any of the termination events reduces throughout the Term } \\
\text { and debt includes the interest owed to the Lenders. The mechanism for calculating each of these is detailed in } \\
\text { the EPA. }\end{array}$} \\
\hline & Termination Event & Compensation \\
\hline & $\begin{array}{l}\text { - Government Event of Default } \\
\text { - Change in Law } \\
\text { - Pakistan Political Event (PPE)Purchaser Termination }\end{array}$ & Debt, Equity and 4 years ROE \\
\hline & $\begin{array}{l}\text { - PPE greater than } 180 \text { days } \\
\text { - Seller termination }\end{array}$ & Debt, equity and 4 years ROE/2 \\
\hline & - Seller Event of Default & $\begin{array}{l}\text { Debt (only if the Purchaser elects to transfer } \\
\text { the facility) }\end{array}$ \\
\hline & - Force Majeure Termination & $\begin{array}{l}\text { Debt and Equity (only if the Purchaser elects } \\
\text { to transfer the facility. }\end{array}$ \\
\hline
\end{tabular}

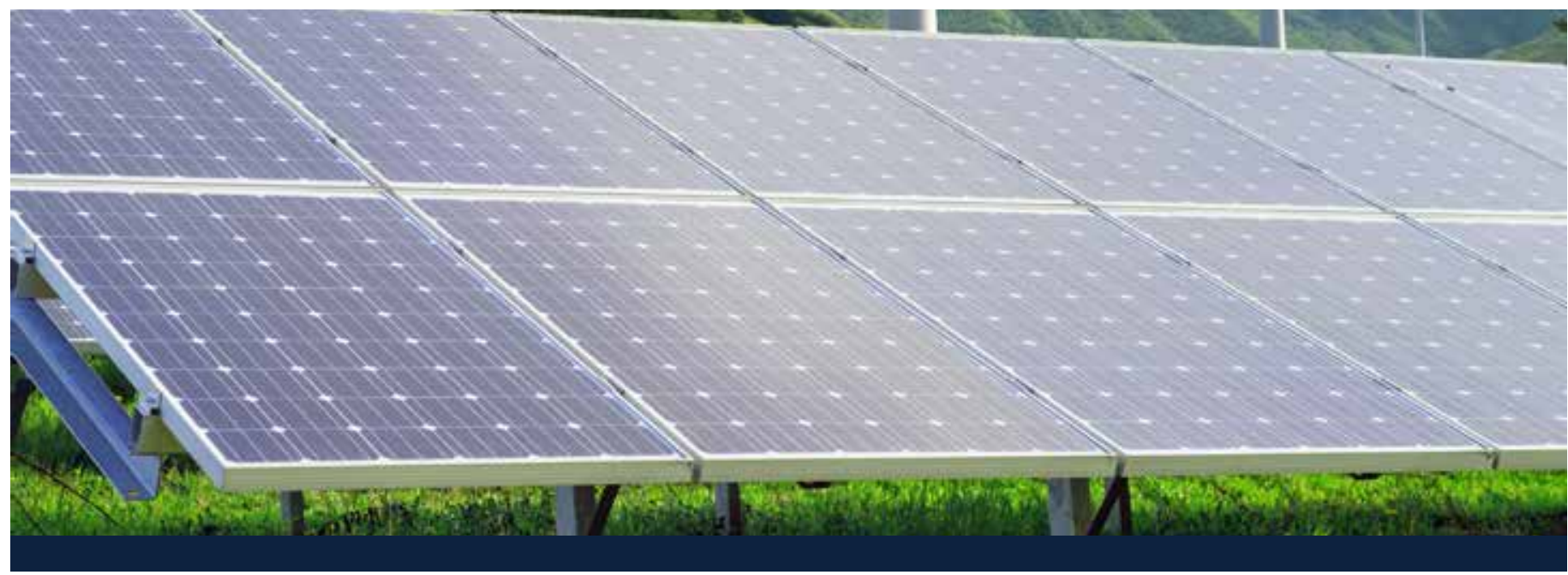




\subsubsection{GRID INTERCONNECTION}

There is no grid connection agreement in Pakistan. The information obtained for the grid connection study needed to obtain the LOS detailed in Section 6.2.2. and any conditions attached to its approval is inserted into the technical schedules of the EPA.

In the standard EPA available on the AEDB website, the off-taker has to design, construct, finance and commission the purchaser interconnection facilities. NTDC has a number of applications for solar projects and there has been some delay in processing them. Additionally, it is NTDC's preference to place a number of small clusters of renewables throughout the grid where there is capacity so that high voltage transmission lines do not need to be exclusively built for solar power projects.

To expedite the construction of transmission lines and the interconnection facility by NTDC or DISCOs, a Project Company may opt to construct and finance these facilities on mutually agreed basis. This has been done by few developers recently. This agreement is outside of the concession documents, and is agreed on a one-on-one basis with NTDC. At the date of publication and to IFC knowledge, no solar or wind developer had agreed to do this.

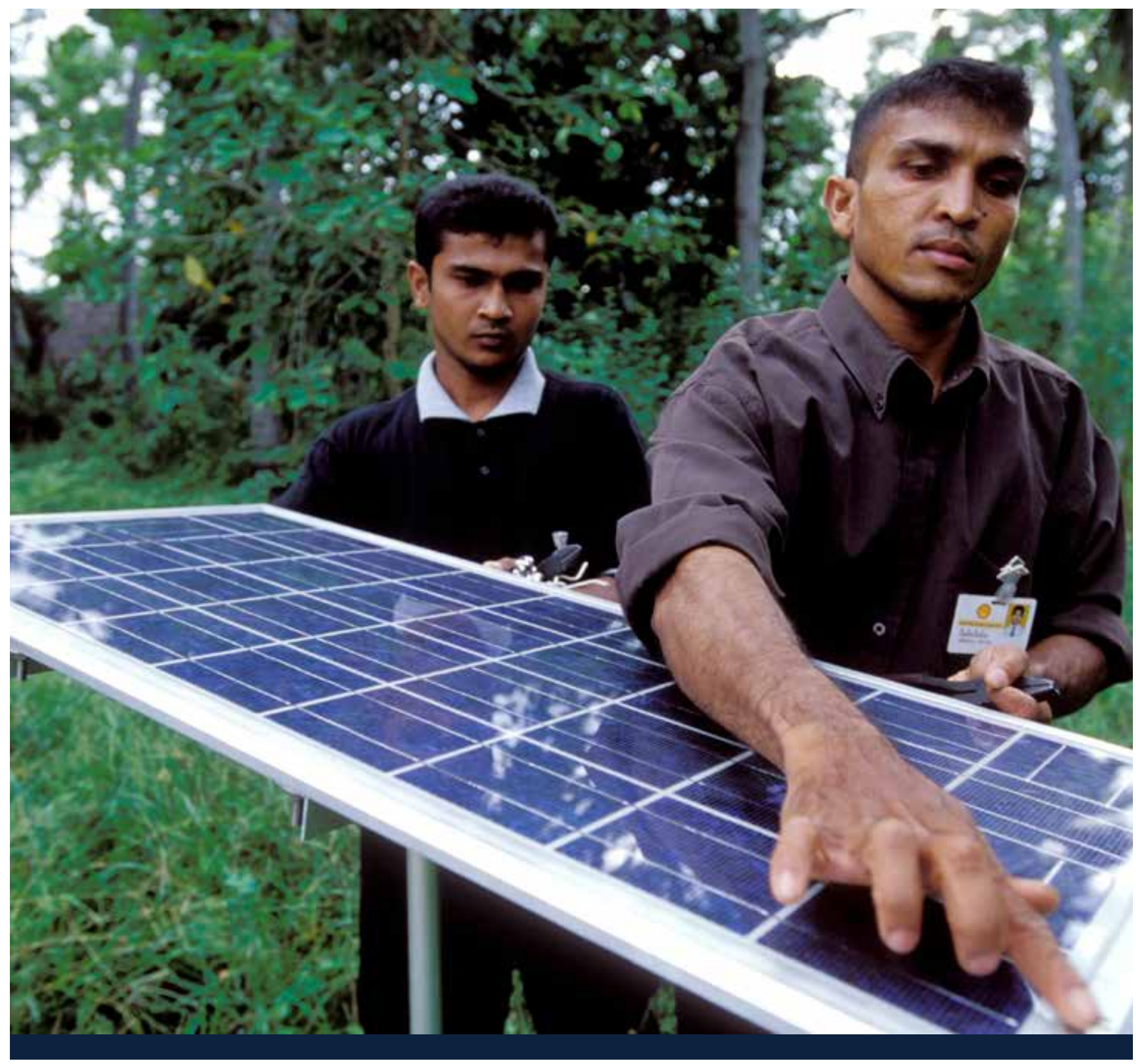




\section{Key Risks in FIT and Mitigants}

The following are the key types of risks along with possible mitigants available under the FIT regime in Pakistan.

\subsection{Security Risks}

Pakistan's security situation has improved substantially in recent years. Country risk perception in financial markets has improved. The Emerging Markets Bond Index Plus risk spread declined from 1011 bps in March, 2013 to 461 bps in April, 2015. Nevertheless, some security concerns remain, particularly in certain parts of the country, and developers should be cognizant of this when deciding on the location and construction of their plant. In public lands designated as solar parks by the provincial governments, some security guarantees may be provided in the lease agreement.

Under the IA, some further protection is provided as follows. In general, the Seller is required to provide security personnel, adequately secured facilities and equipment, and protection for the solar project. However, the GOP ensures that the relevant law and order enforcement agencies shall extend security enforcement on a "non-discriminatory" basis to the Project Company at no cost or expense to the Project Company. From time to time, the Project Company may request additional security forces from the GOP to meet unusual security requirements. All such additional security forces shall remain under the exclusive control and direction of the GOP. All reasonable out-of-pocket expenses incurred by the GOP in providing such security forces requested by the developer shall be reimbursed to the GOP. There is cap on such expenditure which is currently US $\$ 10,000$ for 1 to $5 \mathrm{MW}$, US $\$ 50,000$ for 5 to $20 \mathrm{MW}$, US $\$ 100,000$ for 20 to $50 \mathrm{MW}$ and US $\$ 150,000$ for 50 to $100 \mathrm{MW} .{ }^{57}$

\subsection{Political Risks}

The IA does provide some risk coverage and compensation payments in case of Pakistan Political Force Majeure and Change in Law. However, it is also advisable to obtain credit enhancement from third parties such as the World Banks' Partial Risk Guarantees, associated Multilateral Investment Guarantee Agency (MIGA) guarantees, or similar instruments available from the Asian Development Bank. Certain export credit agencies have associated insurance offerings, such as Chinese Sinosure, which provides risk coverage if the Chinese Export Credit Agency is involved. The Sinosure fee can be passed through under the tariff, which is unique to Sinosure only.

\subsection{Currency Projection and Currency Convertibility}

Currency risks include those in relation to macroeconomic shocks, such as currency devaluation, inflation, and indexation of various tariff cost components. The mitigants available under the Project Documents are through indexation of foreign currency denominated components under the EPA pursuant to the consent of the State Bank of Pakistan and convertibility of local currency to acceptable international currency under the IA. The currency exchange rate is calculated on the date the payment is due and investors have not reported any problems with currency convertibility under EPAs in Pakistan. Also, developers should consider a currency hedge or and insurance document such as the MIGA guarantee detailed in Section 7.4. 


\subsection{Active Risk Mitigating Institutions}

In addition to the mitigants discussed above, there are additional risk-mitigating financial instruments available from various institutions, which the developer can investigate. The developer may be required to purchase some of these by international lenders. The following risk mitigation institutions are active in the Pakistani power sector:

\subsubsection{MULTILATERAL INVESTMENT GUARANTEE AGENCY (MIGA)}

The Multilateral Investment Guarantee Agency (MIGA) is a member of the World Bank Group. Established in 1988, MIGA's role is to promote cross-border investment and lending. It does this by providing risk insurance (guarantees) against certain noncommercial risks to cross-border investments, and by providing dispute resolution services for guaranteed investments. Its clients are debt and equity investors in its 181 member countries. MIGA insures foreign direct investments against the following risks:

a. Currency inconvertibility and transfer restrictions. This is the inability to convert or transfer dividends or loan payments due to foreign exchange restrictions;

b. Expropriation. This is when a government nationalizes or otherwise makes it impossible to operate the project through discriminatory measures;

c. War, civil disturbance, terrorism, and sabotage. This includes the destruction or interruption of business due to political violence;

d. Breach of contract. This is the failure of government to honor obligations under contractual agreements and subsequent failure to honor arbitral awards; and

e. Non-honoring of sovereign financial obligations.

The following are the basic requirements or eligibility criteria for MIGA's coverage:

- Cross-border investments made by investors in a MIGA member country into a developing member country;

- New investments as well as existing investments meeting certain criteria;

- Equity investments, shareholder loans, shareholder loan guarantees, and non-shareholder loans; and

- Investment projects that are financially and economically viable and meet MIGA's social and environmental performance standards (see Section 6.2.4 on EIA, Licenses and Permits).

Investors can go to MIGA's website at www.miga.org and fill out an online application. The MIGA team will review the standard information in confidence. After initial screening, MIGA will contact the investor.

An example of a MIGA guaranteed investment, is the 147 MW Star Hydropower Project being developed by Korea's K-Water and Daewoo E\&C. MIGA issued a guarantee of US \$148.5 million to cover an equity investment in the Patrind Hydropower project being constructed on a 'build, own, operate and transfer' (BOOT) basis, which is a common concessional arrangement in the power sector of Pakistan. The coverage is for the risk of breach of contract for a period up to 20 years. The debt financing is being provided by IFC, ADB, IsDB and the Exim Bank of Korea. 


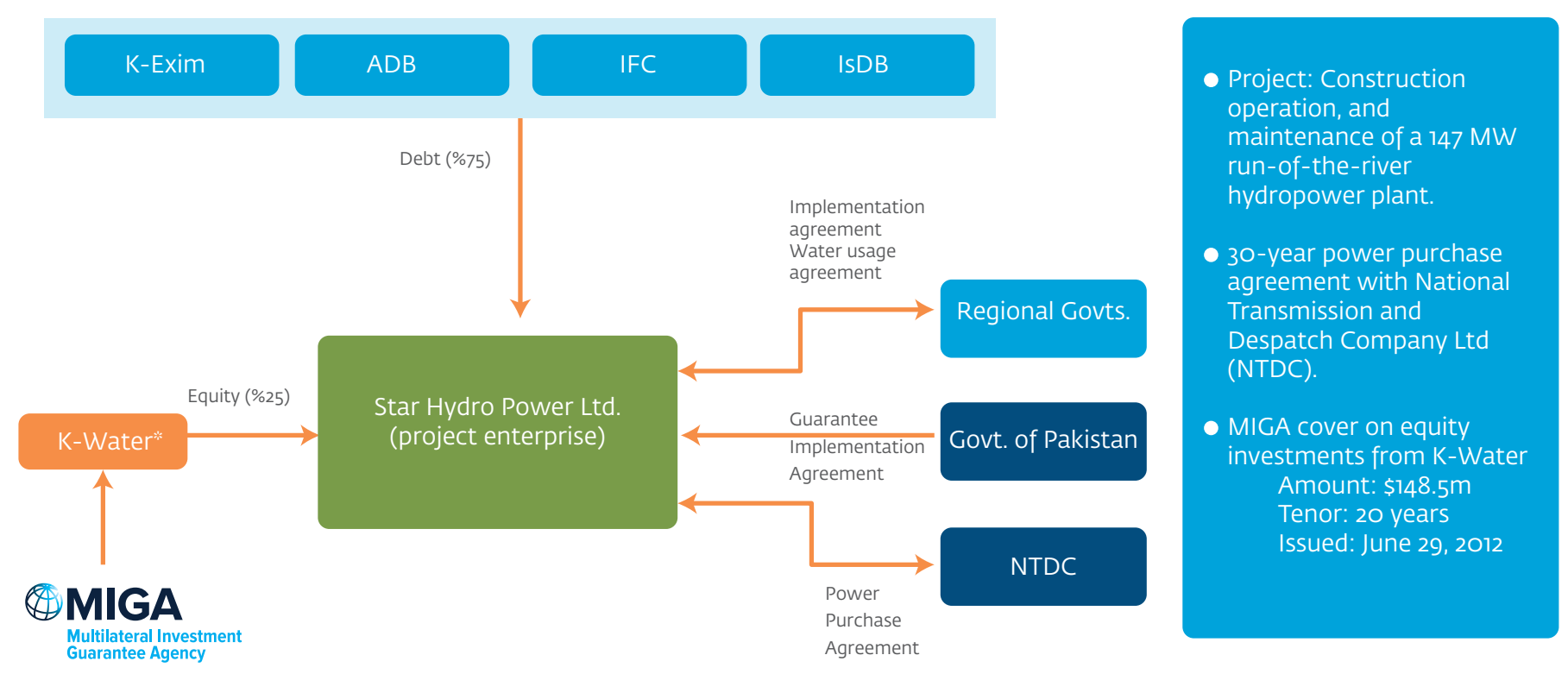

\subsubsection{WORLD BANK (IBRD/IDA)}

The World Bank's risk guarantee program primarily deals with governments and covers risks associated with different kinds of public- and private-sector projects mostly in infrastructure and concessional financing. The following are the guarantees provided by World Bank in order to protect investors:

Partial Risk Guarantees (PRG): PRGs cover commercial lenders for a private sector project against defaults arising from a government-owned entity failing to perform its obligations. PRGs can cover changes in law, failure to meet contractual payment obligations, expropriation and nationalization, currency transfer and convertibility, nonpayment of a termination amount, failure to issue licenses in a timely manner, other risks to the extent they are covered by a contractual obligation of a government entity, and noncompliance with an agreed dispute resolution clause. PRGs can be provided in both IBRD and IDA countries and require a government counter-guarantee.

PRG's can be structured to protect lenders of limited-recourse project finance debt, or to protect the Project Company ("Letter of Credit" or "Deemed Loan" PRGs). ${ }^{58}$

- Eligible projects: Projects with private participation dependent on certain government contractual undertaking, such as: Build-Operate-Transfer (BOT) and concession projects; Public-Private Partnership (PPP) projects; and privatizations. The projects can be both greenfield or existing projects.

- Eligible debt: PRGs can be used for any commercial debt instruments (loans, bonds) provided by any private institution, including debt provided by sponsors in the form of shareholder loans. PRGs can cover both foreign currency and local currency debt. 


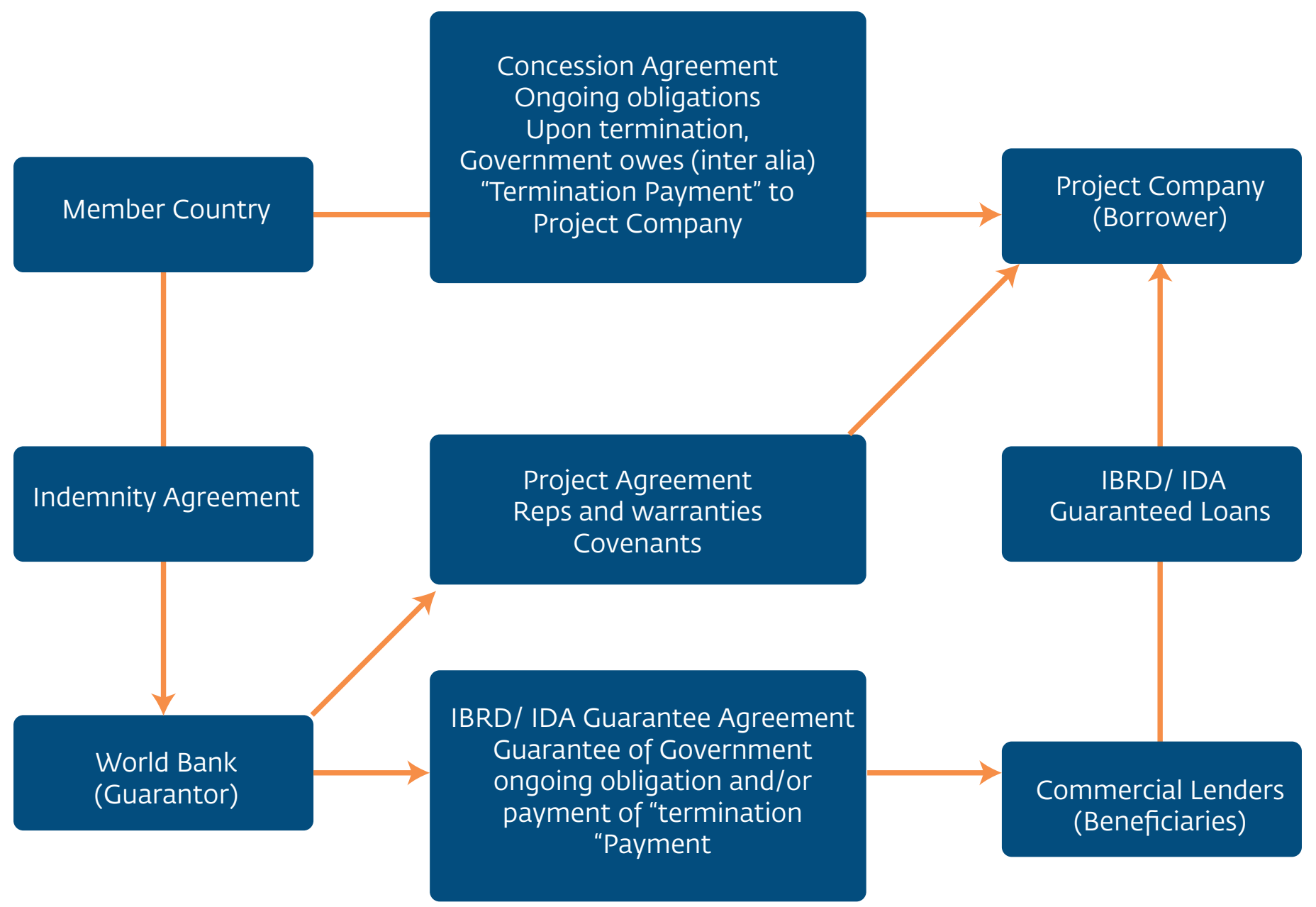

- Risk coverage: PRGs can cover a range of risks relating to government performance including changes in law, failure to meet contractual payment obligations, obstruction of an arbitration process, expropriation and nationalization, foreign currency availability and convertibility, nonpayment of a termination amount or an arbitration award following a covered default, and failure to issue licenses, approvals, and consents in a timely manner.

In Pakistan, the World Bank has provided two PRGs so far. One is for the landmark IPP Hubco Power Project of 1,292 MW provided in 1995 . The coverage was US $\$ 240$ million against the total project cost of US $\$ 1.5$ billion. Another project was the 560 MW Uch Power project in 1996, which received a PRG for US $\$ 67$ million.

\subsubsection{ASIAN DEVELOPMENT BANK (ADB)}

The ADB has been actively involved in supporting the power and energy sector of Pakistan in both the private and public domains. Along with the World Bank Group, the ADB remains one of Pakistan's largest development partners, having provided more than US $\$ 25$ billion in loans, as well as more than US $\$ 200$ million in grants, as of 31 December, $2014 . .^{59}$

The ADB is considered to be one of Pakistan's largest partners in the energy sector, with energy projects comprising more than half of the ADB portfolio for the country. The ADB has committed US $\$ 5.1$ billion in ongoing operational funding to develop Pakistan's energy security, transportation infrastructure, irrigation networks, urban services, social protection services, and reforms. Like other multilaterals, the ADB also offers guarantee products designed to mitigate risk exposure of the financing partners/sponsors. The two primary guarantees are:

59 http://www.adb.org/sites/default/files/publication/27786/pak.pdf 
Political Risk Guarantees (PRGs): To cover political risk, the ADB offers a PRG designed to facilitate co-financing by providing financing partners with coverage against specifically defined political or sovereign risks. Investors are covered through Political Risk Guarantee for the following events:

a.Transfer restriction;

b. Expropriation;

c. Political violence;

d. Contract disputes; and

e. Non-honoring of a sovereign obligation or guarantee.

Like MIGA, the ADB's PRG is designed to facilitate private sector development, either through public or private sector projects. PRGs are well suited where commercial lenders are prepared to accept the commercial (or credit) risks of a project, but not the political risks. The amount that the ADB will guarantee in relation to any one project or transaction will vary depending on a wide variety of factors, including the ADB's assessment of risk and applicable country exposure limitations. At the upper limit, however, the ADB may guarantee up to $40 \%$ of the total project cost (in case of project finance transactions) or US $\$ 400$ million, whichever is lower. These upper limits will not apply if the ADB is protected in the relevant transaction by a counter-guarantee given by the member country's government. Limits lower than those set out above will apply where the ADB has exposure to the project or transaction through direct financing instruments e.g., loan, equity, or credit guarantee.

Partial Credit Guarantees (PCGs): The ADB provides partial credit guarantees (PCGs) to lenders of most forms of debt. These include commercial bank loans, loans made by shareholders, loans guaranteed by shareholders or third parties, capital market debt instruments, bonds, financial leases, LOCs, promissory notes, and bills of exchange.

PCGs cover nonpayment by the borrower or issuer on the guaranteed portion of the principal and interest due. This guarantee product is principally applied to financial services and capital markets (e.g., banking, leasing, insurance, and funds); and infrastructure (e.g., power, transportation, water supply and waste treatment, and telecommunications). Partial credit guarantees can be applied to loans or other debt instruments issued by private and public sector projects (limited recourse financings), PPPs, corporates, and (sub) sovereign entities.

\subsubsection{OTHER FINANCIAL INSTITUTIONS}

There are other international institutions investing and providing certain coverages in the power sector of Pakistan. These include France's PROPARCO (de Promotion et de Participation pour la Coopération Economique), EXIM Bank of Korea, EXIM Bank of China, FMO (Netherlands Development Finance Company), Chinese Sinosure, OPOC and the Islamic Development Bank.

For more details on other public and private sector entities that provide risk coverage through partial risk guarantees, partial credit guarantees and political risk insurance, please see http://www.globalclearinghouse.org/InfraDev/rmlist.cfm.

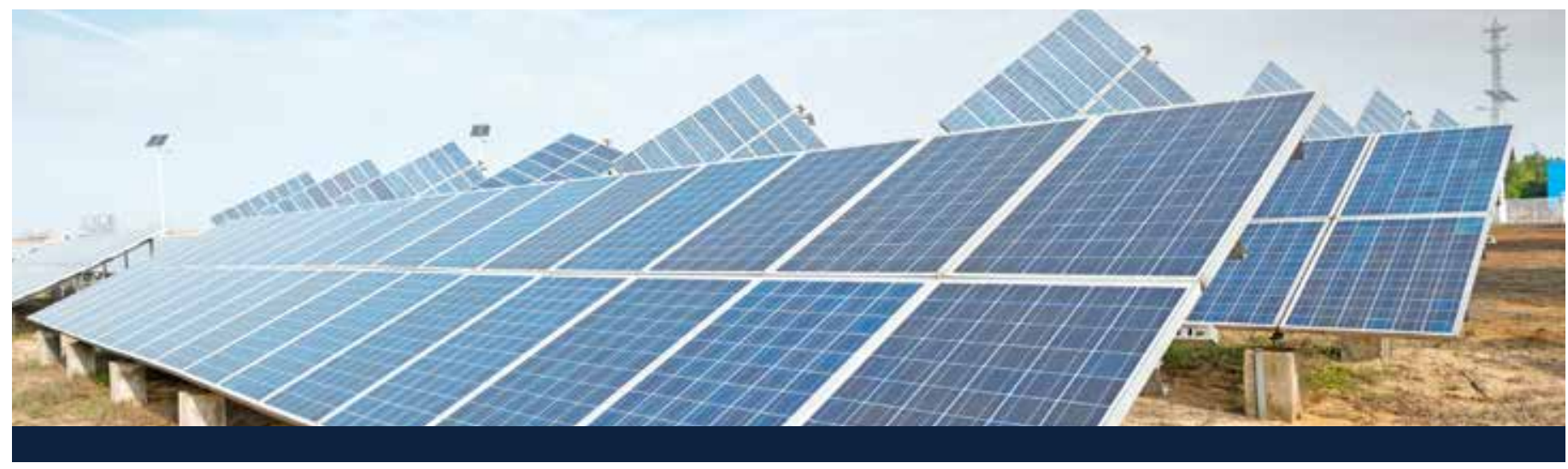




\section{Fiscal Regime and Taxation on Renewables}

\subsection{Income Tax}

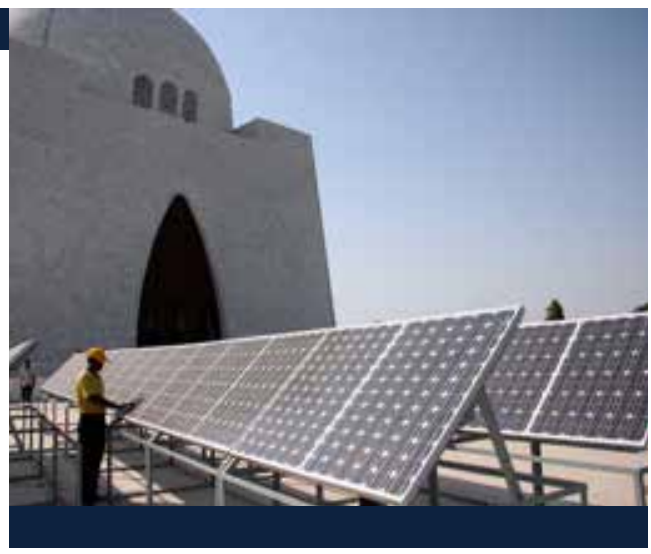

INCOME TAX ON SALE OF ELECTRICITY

There is no tax on income derived from generation of electricity since renewable energy and all power projects are exempted from income tax in Pakistan. ${ }^{60}$

A further exemption is provided in respect of turnover tax (minimum tax). ${ }^{61}$ Turnover tax or minimum tax is applicable in situations where the taxpayer has no corporate tax liability, is exempt from tax or corporate tax liability is less than $1 \%$ of turnover. ${ }^{62}$ Normally, persons exempt from corporate tax are still liable to pay turnover tax or minimum tax on the basis on their gross turnover (which has been defined above). However, taxpayers engaged in the generation of electricity are also exempt from turnover tax.

\section{INCOME TAX ON OTHER SOURCES OF INCOME}

Income from sources other than the generation of electricity, including interest income, is taxable at the corporate tax rate of $32 \%$ for tax year 2016. Income, including interest income, received by a corporate person in a tax year is chargeable to tax on the rates applicable to the relevant year. As of now, the Income Tax Ordinance, 2001 (the 2001 Ordinance) provides specific tax rates for 5 years up to TY18, as shown in Table 10 below:

\section{TABLE 10: PAKISTAN CORPORATE TAX RATES}

\begin{tabular}{|l|l|}
\hline Tax Year & Rate \\
\hline TY16 & $32 \%$ \\
\hline TY17 & $31 \%$ \\
\hline TY18 & $30 \%$ \\
\hline
\end{tabular}

Source: 2001 Ordinance

Although the 2001 Ordinance states that from tax year 2019 onwards, the tax rate would revert back to 35\% (the income tax rate prior to TY14), it may be noted that the gradual reduction in corporate tax rates was in line with a government policy initiated at the request of the corporate sector. Accordingly, the tax should at minimum remain static at $30 \%$. However, this cannot be authoritatively confirmed.

The tax rates for individuals are based on progressive slabs. For salaried individuals, the tax rates vary from $0 \%$ to $30 \%$, whereas for non-salaried individuals, the rates vary from $0 \%$ to $35 \%$. The rates of tax to be applied to each progressive slab are set out in Annex 5.

\subsection{Withholding Tax \\ WITHHOLDING TAX ON DIVIDENDS}

As per Section 152 of the 2001 Ordinance, every person making a payment to a non-resident is required to withhold tax at the specified rate. Withholding tax on dividends is not permitted as a Pass-Through Item under the tariff for wind and solar power projects. The withholding tax rate on dividends for wind and solar power projects is $7.5 \%$.

60 http://www.adb.org/sites/default/files/publication/27786/pak.pdf

61 Clause 11A(5), Part IV, Second Schedule, Income Tax Ordinance, 2001

62 Turnover tax is defined in section 113 of the Income Tax Ordinance, 2001. 


\section{WITHHOLDING TAX ON INTEREST}

Pursuant to the aforementioned section, the company will have to withhold tax on interest payments made to foreign lenders at the rate of $20 \%$. However, the rate is reduced to $10 \%$ for non-residents not having a Permanent Establishment in Pakistan. Such a withholding tax would constitute an advance payment of tax against the final tax liability of the lender, which for a company would be calculated on a bottom-line basis at the prevalent corporate tax rate. Following that, the lenders would be required to file returns of income in Pakistan. A refund may be claimed on account of excess deduction of tax, if any.

\subsection{Provincial Taxes}

In Pakistan, income taxes are levied only by the Federal Government. The provinces have been empowered only to the extent of indirect tax related to provision of services. Hence, no income tax or provincial withholding tax would apply in respect to dividends.

\subsection{Custom and Import Duties}

Equipment for renewable energy projects is exempted from import duties. Effective 1st July,2015, this exemption has now been incorporated under Heading 12 of the Fifth Schedule to the Customs Act, 1969. The heading provides an exemption for all plant, machinery and spare parts imported for renewable energy projects (subject to certain conditions). A similar exemption is also available in relation to collection of sales tax at import stage (Table 3, Heading 7, Sixth Schedule, Sales Tax Act, 1990) and income tax at import stage (Clause 76, Part IV, Second Schedule, Income Tax Ordinance, 2001).

\subsection{Sales Tax/VAT/Turnover Tax}

Generally, sales tax is charged in Pakistan at the rate of $17 \%$. Solar projects are not exempt from sales tax, but in the case of the sale of electricity, NEPRA has provided that this can be passed through to the off-taker under the EPA.

\subsection{Zakat (Islamic Tax)}

Zakat is typically charged at a rate of $2.5 \%$ on dividends paid to Muslim shareholders. However, it is exempted for all non-Muslim and non-resident shareholders.

\subsection{Other Incentives}

NEPRA has provided that equity repatriation and dividends are permitted. Permission required for equity repatriation and dividends to foreign investors can be granted by the State Bank of Pakistan (SBP) and is required prior to financial close under the IA. The initial investment made by foreign investors may be remittable to the shareholders only if it was registered with the SBP as eligible for equity repatriation, i.e., the initial foreign investment received by the investee company is declared as a foreign direct equity investment in the name of the investor and is registered as such by the SBP upon issuance of a Proceeds Realization Certificate to the shareholders. These consents from SBP are to be obtained pursuant to the IA.

If at the time of investment, the investment is granted equity repatriation, the same shall be available for remittance to the investors without taxability in Pakistan. Alternatively, if no such permission was obtained, the capital investment may not be remitted back to its owners.

Sponsors can raise local and international financing including corporate bonds. Also non-residents are allowed to buy shares of power companies without central bank permission.

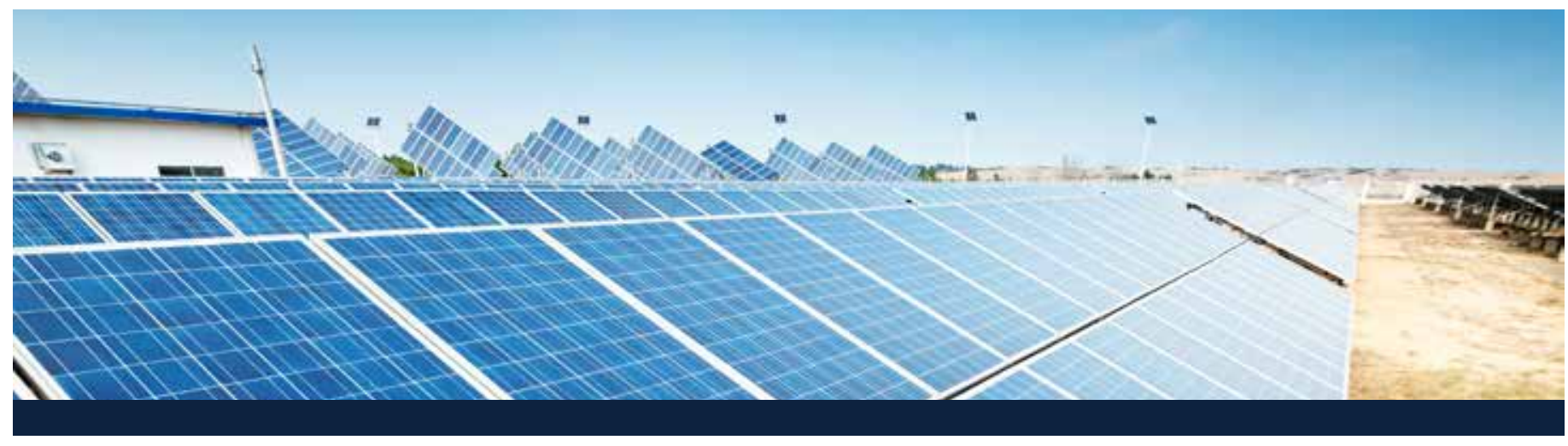




\section{Challenges and Recommendations}

The major issues identified with the input of various developers, observations from FIT determination in addition to industry norms are as per below:

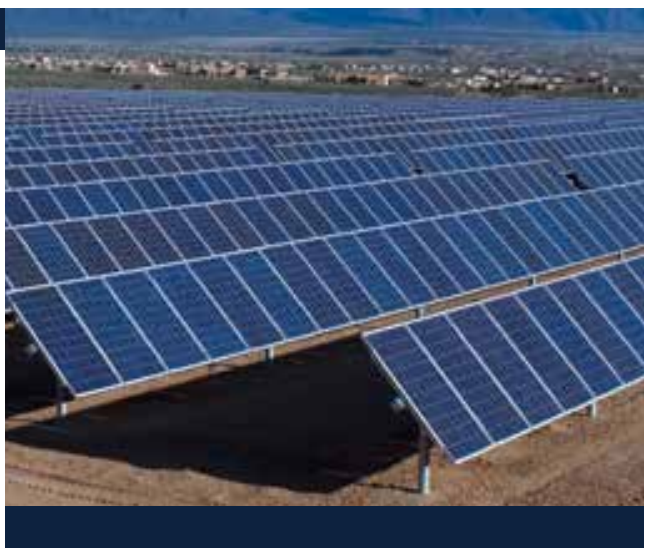

\subsection{Timeline and Policy Uncertainty}

No privately financed solar IPP has reached financial close in Pakistan. It is understood that projects awarded tariffs under the 2014 and 2015 FIT determinations have been stalled as the Central Power Purchase Agency (CPPA) has been waiting for a lower tariff. This has impacted investor confidence. NEPRA is clear that the CPPA must honor those tariffs and has been consistent in granting extensions for developers to the timelines for financial close where government organizations have not been cooperative. However, at the time of printing, this situation has yet to be resolved.

In addition, the issuance of LOIs by AEDB and provincial agencies had stalled in 2015 on the basis that a new tariff was expected. It is hoped that this will resolve itself on publication of the 2016 tariff.

\subsection{Land Identification}

Land identification is one of the main hurdles for international developers looking to enter the Pakistani market. If a local partner is not found who already has land access, it may take some time to identify lands that are suitable for development. This is further hampered by a lack of public access to good digitalized maps.

The AEDB and the Government of Sindh are trying to make the process more investor friendly by identifying lands for development.

\subsection{Transmission Issues}

NTDC has a number of applications pending for solar projects and due to the regulatory uncertainty has not been processing applications as quickly as the timelines require.

The Grid Interconnection approval process takes time in Pakistan. Under the 2006 RE Policy, NTDC is required to provide grid interconnection but this can take time and funding. It is recommended that NTDC is approached as soon as possible and that developers work with them and local consultants to identify areas that are most suitable for evacuation of power and that do not require substantial construction of transmission lines. 

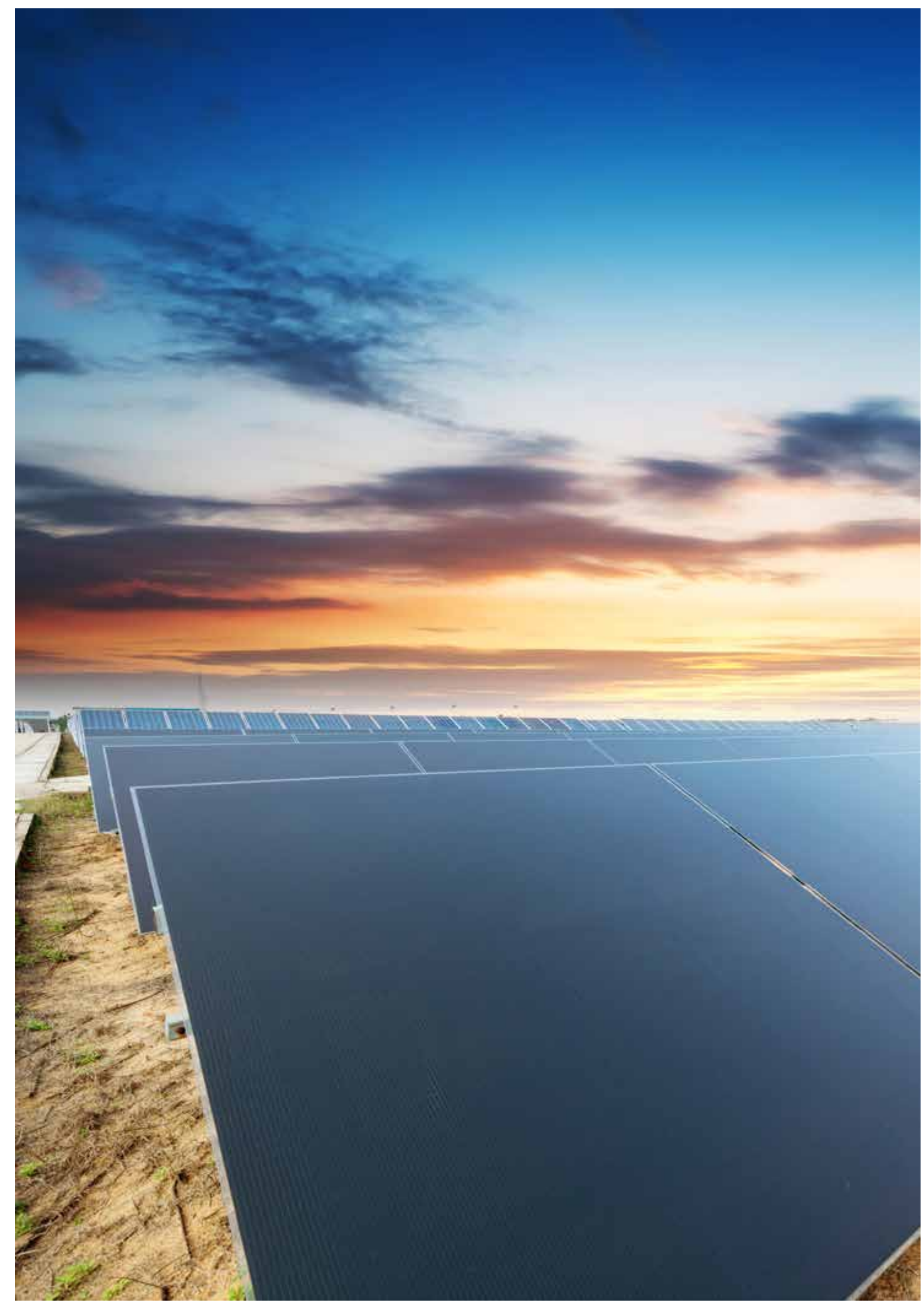


\section{Annex 1}

\section{REFERENCES}

\section{LEGISLATION AND REGULATION}

- Policy for Development of Renewable Energy Generation, Government of Pakistan, 2006 (the 2006 Policy)

- Available at: http://www.aedb.org/Documents/Policy/REpolicy.pdf

- National Electric Power Regulatory Authority (Alternative and Renewable Energy) Distributed Generation and Net Metering Regulations, 2015

- Available at: http://www.nepra.org.pk/Legislation/Regulations/NOTIFICATION\%20SRO\%20892\%20-2015.PDF

- National Electric Power Regulatory Authority Licensing (Application and Modification Procedure) Regulations, 1999

- Available at: http://www.nepra.org.pk/Legislation/Regulations/NEPRA\%20Licensing\%20(Application\%20\%20Modification \%20Procedure)\%20Regulations\%201999\%20along\%20with\%20all\%20amendments.pdf

- NEPRA (Tariff Procedures and Standards) Rules 1998

- Available at: http://www.nepra.org.pk/Legislation/Rules/NEPRA\%20(Tariff\%20Standards\%20and\%20Procedure)\%20Rules\%201998\%20along\%20with\%20all\%20amendments.pdf

- Grid Code Addendum No. II for Grid Integration of Photovoltaic (PV) \& Concentrated Solar Power (CSP) Plants.

Available at:

http://www.nepra.org.pk/Legislation/Codes/Grid\%20Code\%20Addendum\%20No.II\%20(NTDC) \%2030-06-2014.PDF

Review of IEE and EIA Regulations 2000

Found at: http://epd.punjab.gov.pk/system/files/REVIEW\%20OF\%20IEE\%20AND\%20EIA\%20REGULA-

TIONS\%2C\%202000.doc.pdf

\section{NEPRA SOLAR TARIFF DETERMINATIONS}

- 21st January 2014, Determination of National Electric Power Regulatory Authority in the Matter of Upfront Tariff for Solar Power Plants. Available at: http://www.nepra.org.pk/Tariff/Upfront/TRF-UTS\%20UPFRONT\%20SOLAR\%20 DETERMINATION\%2021-01-2014\%20777-79.PDF

- 22nd January 2015, Determination of National Electric Power Regulatory Authority in the Matter of Upfront Generation Tariff for Solar PV Power Plants. Available at: http://www.nepra.org.pk/Tariff/Upfront/2015/Determination\%20 of\%20NEPRA \%20in\%20Upfront\%20Tariff\%20for\%20Solar\%20PV\%20Power\%20Plants.pdf

- 25th May 2015, Decision of the Authority in the Matter of Motion for Leave for Review filed against the Determination of the Authority dated 22.01.2015 regarding Upfront Generation Tariff for Solar PV Power Plants. Available at: http://www.nepra.org.pk/Tariff/Upfront/2015/UTS-01\%20REVIEW\%20DETERMINATION\%20SOLAR\%20PP\%20 25-05-2015\%207915-17.PDF

- 16th December 2015, Determination of National Electric Power Regulatory Authority in the Matter of Upfront Generation Tariff for Solar PV Power Plants. Available at: http://www.nepra.org.pk/Tariff/Upfront/2015/Determination \%20 of \%20NEPRA \%20in \%20the\%20matter\%20of\%20Upfront\%20Generation \%20Tariff\%20for\%20Solar\%20 Power\%20Projects.PDF 


\section{LAND}

- Statement of Conditions for land allocation and land lease for Solar Power Projects in the Punjab 9th May 2014. Available at: http://energy.punjab.gov.pk/downloads/QASP_LANDALLOCATION_SOC_09122014.pdf

- Land Grants Policy for Solar and Alternative Energy in Sindh, 11th June 2015.

- Available at: Annex 7 of this document

\section{WEBSITE}

- Alternative Energy Development Board: http://www.aedb.org

- National Electric Power Regulatory Authority: http://www.nepra.org.pk

- National Transmission and Despatch Company: http://www.ntdc.com.pk

- Sindh Energy Department: http://sindhenergy.gov.pk

- Punjab Energy Department: http://energy.punjab.gov.pk 


\section{Annex 2}

\section{Pakistan Macroeconomic Update}

\section{World Bank Presentation 13 October 2015}

\section{Pakistan Macroeconomic Update}

\section{IMPROVED ECONOMIC CONDITIONS}

- Inflation declined to $4.5 \%$ in FY15

- Fiscal deficit contained at $5.3 \%$ of GDP due to high non-tax revenues and restricted expenditures, compared to $5.6 \%$ in FY14

- State Bank of Pakistan cut its key policy rate by 300 bps in FY15, owing to a decline in inflation (global oil price decline a factor)

\section{GROWTH}

- Growth of $4.2 \%$ in FY15 compared to 4\% in FY14, driven by services and agriculture, weaker than expected manufacturing performance

- Growth maintains upward momentum, but remains below required levels to accelerate job creation

\section{BALANCE OF PAYMENTS}

- Foreign exchange reserves reached US \$13.6 billion on 30th June 2015

- Current Account deficit modest at $0.8 \%$ of GDP

- Less risk of a Balance of Payments crisis, as foreign exchange reserves supported by increased remittances of US $\$ 18.5$ billion, decline in oil price and inflows from IFIs/donors

\section{PRIVATE SECTOR CREDIT}

- Private sector credit growth has slowed, 5.6\% increase in borrowing from commercial banks in FY15, lower than FY14

- Increased budgetary borrowings continue to crowd out the private sector

Country Risk

- Country risk perception has improved, Emerging Markets Bond Index Plus risk spread declined from 1011bps in March 2013 to 461 bps in April 2015

- S\&P credit rating changed from stable to positive in May 2015, rating at B-

- IMF Program on track: 36 month EFF with IMF, received US $\$ 4.77$ billion after eight successful quarterly program reviews

The outlook from FY15 to FY19 is for moderately higher economic growth, based on following conditions: 


\section{GROWTH}

- If the Government's medium-term program to remove constraints to growth shows steady progress, i.e., electricity load-shedding, loss-prone SOEs, low access to finance, and poor revenue mobilization

- Political and security risks are well managed

- GDP growth reaches $4.5 \%$ in FY16 (the Government aims for 6\%), and rises to 5.2\% from FY18 onwards

\section{BALANCE OF PAYMENTS}

- The Current Account deficit increases to 1\% of GDP in FY17, slightly up from $0.8 \%$ of GDP in FY15

- Foreign exchange reserves reach 3.9 months of import coverage by FY16, compared to 3.3 months by the end of FY15

- Slightly higher foreign investment inflows under CPEC and initial privatizations, multilateral financial net inflows decline

- Gross financing requirements reach US $\$ 7.7$ billion by FY17

\section{FISCAL DEFICIT}

Consolidated fiscal deficit is cut in half, from $5.3 \%$ of GDP in FY 15 to $2.8 \%$ in FY19

\section{PRIVATE SECTOR CREDIT}

Fiscal consolidation reduces government borrowing needs, and a positive external sector improves financing conditions for the private sector

\section{PUBLIC DEBT}

Public Debt to GDP ratio declines to $62.9 \%$ in FY17, from $64.6 \%$ in FY15 


\section{Annex 3}

\section{Indexation Mechanism for Foreign and Local O\&M Cost}

The O\&M component of the tariff will be adjusted on account of local Inflation (CPI) and foreign inflation (US CPI) and exchange rate quarterly on 1st July, 1st October, 1st January and 1st April based on the latest available information with respect to CPI notified by the Pakistan Bureau of Statistics (PBS), US CPI issued by US Bureau of Labor Statistics and revised TT \& OD selling rate of US Dollar notified by the National Bank of Pakistan as per the following mechanism for the 2016 Tariff:

\begin{tabular}{|l|l|l|l|}
\hline L O\&M(Rev) & $=$ & $70 \%$ O\&M(Ref)* CPI (Rev)/CPI (Ref) \\
\hline F O\&M(Rev) & $=$ & $30 \%$ O\&M(Ref)* US CPI(Rev)/US CPI(Ref)*ER(Rev)/ER(Ref) \\
\hline Where & $=$ & The revised applicable O\&M Local Component of Tariff \\
\hline L O\&M(Rev) & $=$ & The revised applicable O\&M Foreign Component of tariff \\
\hline F O\&M(Rev) & $=$ & The reverence O\&M component of tariff for North Region Rs. 1.8715/kWh and for South Region Rs. 1.7674/kWh \\
\hline O\&M(Ref) & $=$ & The revised Consumer Price Index (General) published by the Pakistan Bureau of Statistics \\
\hline CPI(Rev) & $=$ & The reference Consumer Price Index (General) of 201.620 for the month of July 2015 \\
\hline CPI(Ref) & $=$ & The revised US CPI (All Urban Consumers) published by US Bureau of Labor Statistics \\
\hline US CPI(Rev) & $=$ & The reference US CPI (All Urban Consumers of 238.654 for the month of July 2015 \\
\hline US CPI(Ref) & $=$ & The revised TT \& OD selling rate of US dollar published by the National Bank of Pakistan \\
\hline ER(Rev) & $=$ & The reference TT \& OD selling rate of PKR 105/US \$ \\
\hline ER(Ref) &
\end{tabular}

\section{Indexation for LIBOR}

\begin{tabular}{|l|l|l|}
\hline$\Delta \mathrm{I}$ & $=$ & $\mathrm{P}(\mathrm{Rev}) *(\mathrm{LIBOR}(\mathrm{Rev})-0.31 \%) / 4$ \\
\hline Where & $=$ & $\begin{array}{l}\text { The variation in interest charges applicable corresponding to variation in } 3 \text { months LIBOR. } \Delta \mathrm{I} \text { can be positive or } \\
\text { negative depending upon whether LIBOR(Rev) is >0r<0.31\%. The interest payment obligation will be enhanced } \\
\text { or reduced to the extent of } \Delta \mathrm{I} \text { for each quarter under adjustment applicable on quarterly basis. }\end{array}$ \\
\hline$\Delta \mathrm{I}$ & $=$ & $\begin{array}{l}\text { The outstanding principal (as indicated in the attached debt service to the NEPRA tariff determination) on a } \\
\text { quarterly basis on the relevant quarterly calculation date. Period } 1 \text { shall commence on the date on which the } \\
\text { first installment is due after availing of the grace period. }\end{array}$ \\
\hline
\end{tabular}

\section{Indexation of Return on Equity}

After COD, the ROE component of the tariff will be quarterly indexed on account of variation in PKR/US \$ parity according to the following formula:

\begin{tabular}{|c|c|c|}
\hline ROE(Rev) & $=$ & $\operatorname{ROE}(\operatorname{Ref}) * \mathrm{ER}(\operatorname{Rev} / \mathrm{ER}(\mathrm{Ref})$ \\
\hline \multicolumn{3}{|l|}{ Where } \\
\hline ROE(Rev) & $=$ & Revised ROE Component of Tariff \\
\hline $\mathrm{ROE}(\mathrm{Ref})$ & $=$ & ROE Component of Tariff established at the time of COD \\
\hline ER(Rev) & $=$ & The revised TT \& OD selling rate of US dollar as notified by the National Bank of Pakistan \\
\hline $\mathrm{ER}(\mathrm{Ref})$ & $=$ & Reference Exchange Rate at the time of COD \\
\hline
\end{tabular}




\section{Insurance Adjustment for Actual Insurance Cost}

The actual insurance cost for the minimum cover required under contractual obligations with the power purchaser not exceeding $1 \%$ of the EPC cost will be treated as a pass-through. Insurance component of the reference tariff shall be adjusted annually as per actual upon production of authentic documentary evidence according to the following formula.

\begin{tabular}{|l|l|l|}
\hline AIC & $=$ & $\operatorname{Ins}($ Ref)/P(Ref)*P(Act) \\
\hline Where & $=$ & Adjusted Insurance Component of Tariff \\
\hline AIC & $=$ & Reference Insurance Component of Tariff \\
\hline Ins(Ref) & $=$ & Reference Premium 1\% of EPC cost at PKR 105/US $\$$ \\
\hline P(Ref) & $=$ & $\begin{array}{l}\text { Actual Premium or 1\% of the EPC cost in PKR on exchange rate prevailing on first day of the insurance cover- } \\
\text { age period whichever is lower }\end{array}$ \\
\hline P(Act)
\end{tabular}




\section{Annex 4}

\section{Standard Letter of Support}

\section{ALTERNATIVE ENERGY DEVELOPMENT BOARD Letterhead}

[Date]

Name and address of the

Main Sponsor

Subject: LETTER OF SUPPORT FOR THE ESTABLISHMENT OF A [•] POWER GENERATION FACILITY HAVING INSTALLED CAPACITY OF $[\bullet] \mathrm{MW}($ LOCATED AT $[\bullet]$, PROVINCE OF , PAKISTAN

Dear Sir,

\section{A. REFERENCE}

$[\bullet]$, a company incorporated under the Companies Ordinance, 1984, under certificate of incorporation no. $[\bullet]$ dated $[\bullet]$, (the "Project Company"):

(i) having received the Letter of Intent dated January 30 ,2014 from Alternative Energy Development Board (“AEDB”) whereby AEDB has confirmed its interest in the Project, as defined herein and, where applicable, the successful submission of a feasibility study; and

(ii) having received from NEPRA a Tariff Determination No $[\bullet]$ dated $[\bullet]$ on the terms and conditions set out therein as amended from time to time (the "Tariff Determination" and the tariff determined pursuant thereto, the "Tariff"); and

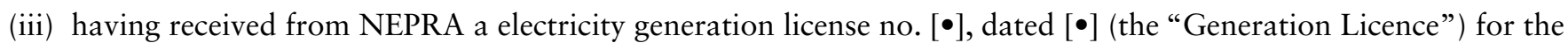
generation of electric power on the terms and conditions set out therein,

is now issued this Letter of Support (the "LOS"), on the terms and conditions set out herein, by AEDB for the development, design, engineering, manufacture, procurement, financing, construction, completion, testing and commissioning, insurance, ownership, operation and maintenance of an approximately [•]MW ( ISO gross installed capacity) power generation facility (the "Complex") to be located near [•], Province of $[\bullet]$ and all activities incidental thereto (the "Project").

The Complex shall be a renewable electricity generation facility utilizing $[\bullet]$ as the renewable energy resource for generation of electricity.

The Project Company has posted in favor of AEDB an irrevocable, unconditional, on demand, without recourse, bank guarantee on terms acceptable to AEDB dated $[\bullet]$ issued by (name of issuing bank ) (the "Performance Guarantee") in the amount of US Dollars [•]. The Performance Guarantee secures the Project Company's obligations to execute the Project Agreements (reference paragraph B(1)), to achieve Financial Closing (reference paragraph $\mathrm{B}(2)$ ) and to pay the Termination Amount (reference paragraph B(6)) under and in accordance with the terms of this LOS. The Performance Guarantee shall remain valid and in full force till the expiry of three (3) months beyond the Required Financial Closing Date (as specified in paragraph $\mathrm{B}(2)$ ) provided however, in the event the Financial Closing is achieved on or prior to the Required Financial Closing Date, the Performance Guarantee shall be returned to the Project Company on the date of its achievement of Financial Closing,. The Performance Guarantee shall be encashable in accordance with the terms of this LOS at any time prior to Financial Closing, on call at any time during the period of its validity by AEDB. The Project Company hereby agrees that it shall have no claim against AEDB, the Government of Pakistan (the "GOP"), the Government of $[\bullet]$ (the "GO[•]") or any agency or instrumentality or component thereof on any grounds whatsoever if AEDB acting in its sole discretion shall make any call upon or encash the Performance Guarantee; provided that such call or 
encashment is made in accordance with the terms of this LOS, and the Project Company hereby waives, to the fullest extent permissible by law, any such claim. It is agreed that the amounts encashed under the Performance Guarantee in accordance with the terms of this LOS are reasonable and constitute liquidated damages to the GOP and AEDB for the Project Company's failure to (as applicable) (a) execute the Project Agreements (reference paragraph B(1)), (b) timely achieve Financial Closing (reference paragraph B(2)) and (c) pay the Termination Amount (reference paragraph B(6)), in each case, in accordance with the terms of this LOS, and it is understood and agreed that the encashment in full of the Performance Guarantee by the AEDB is in lieu of actual damages for such occurrence and the collection of such sums pursuant to such Performance Guarantee pursuant to this LOS is the sole remedy of the GOP and AEDB for such events.

Until Financial Closing (as defined hereinafter), this LOS and the provisions of the Project Agreements (as defined hereunder) that become effective immediately upon signing of the Project Agreements shall govern the implementation of the Project and shall supersede all other documents and agreements. In the event of any conflict between this LOS and the provisions of the Project Agreements that become effective upon signing, this LOS shall govern and prevail. Effective on the date Financial Closing is achieved by the Project Company, the Project Agreements shall supersede the LOS. AEDB shall cancel and return the Performance Guarantee to the Project Company on the date Financial Closing is achieved.

\section{B. AUTHORIZATION}

AEDB hereby conveys its permission to the Project Company to implement the Project in accordance with the terms of this LOS and, when the Project Agreements become effective, in accordance with the Project Agreements. Electricity produced by the Complex shall be sold to the National Transmission and Despatch Company Limited (through its Central Power Purchasing Agency) on behalf of ex-WAPDA distribution companies (the "Purchaser") in accordance with the Generation License, Tariff Determination and the provisions of the Energy Purchase Agreement ("EPA") to be entered into between the Project Company and the Purchaser. The Project Company shall be responsible for performing and causing the performance of all activities necessary and incidental to its obligations under this LOS, including the following:

1. The Project Company shall, on or prior to the Required Financial Closing Date or (if applicable in terms of this LOS) the Extended Required Financial Closing Date, negotiate and sign an Implementation Agreement ("IA") with the President of the Islamic Republic of Pakistan and an EPA with the Purchaser, failing which the Performance Guarantee shall be encashed for the full amount thereof by AEDB provided that if the delay is caused by the actions of the GOP, AEDB or the Purchaser, then, the Project Company shall not be penalized.

The IA and EPA are collectively referred to in this LOS as the "Project Agreements".

2. Unless Financial Closing is delayed or not achieved on account of any Consents (as defined in the IA) not being issued to the Project Company despite its compliance with its obligations under the IA relating thereto by the Required Financial Closing Date or the Extended Financial Closing Date, the Project Company shall achieve Financial Closing no later than [insert date] (the "Required Financial Closing Date"), failing which the Performance Guarantee shall be encashed in the full amount thereof by AEDB, provided that if the delay is caused by actions of the GOP, AEDB or the Purchaser, then, the Project Company shall not be penalized. In addition to any other consequences set out in the Project Agreements, if AEDB determines that any delay by the Project Company in achieving Financial Closing by the Required Financial Closing Date is due to events beyond the reasonable control of the Project Company or that Financial Closing can be achieved shortly, AEDB shall be entitled (acting on an application in writing made to it by the Project Company at least thirty (30) days before the Required Financial Closing Date to grant in writing to the Project Company a one time extension of up to a maximum period of six (6) months beyond the Required Financial Closing Date (such extended date being hereinafter referred to as the "Extended Required Financial Closing Date" and this LOS shall stand correspondingly extended on the same terms and conditions for such additional period. No claim for an extension to the Required Financial Closing Date and the period of validity of this LOS shall be accom- 
modated or considered by AEDB unless the following actions are taken by the Project Company to the satisfaction of AEDB (i) the Project Company extends the period of validity of the Performance Guarantee so that the Performance Guarantee is valid on the same terms and conditions up till three (3) months beyond the Extended Required Financial Closing Date; and (ii) the maximum amount in which the Performance Guarantee can be called is doubled. Following any extension as aforesaid, the Project Company shall submit monthly reports that set out in adequate detail the additional efforts made by the Project Company to achieve Financial Closing no later than the Extended Required Financial Closing Date and the progress achieved in that regard. In the event the Performance Guarantee is extended in accordance with the terms of this LOS up till three (3) months beyond the Extended Required Financial Closing Date, such Performance Guarantee shall expire and shall be returned to the Project Company on the date falling on the earlier of: (i) the date on which Financial Closing is achieved by the Project Company; (b) the date falling three (3) months after the Extended Required Financial Closing Date.

3. For the purposes of this LOS, "Financial Closing" means (a) the execution and delivery of the Financing Documents (as defined in the IA) that together with equity commitments evidence sufficient financing for the construction, testing, completion, and commissioning of the Complex (following the resolution of any objections raised by AEDB to a term sheet or debt repayment schedule that sets out a principal repayment schedule and the other principal terms of the transaction between the Project Company and the Lenders (as defined in the IA)) and the evidence of commitments for such equity as is required by the Project Company to satisfy the requirements of the Lenders and this LOS and the satisfaction, waiver or deferral of all conditions precedent for the initial availability of funds under the Financing Documents, and (b) the delivery of the Seller Letter of Credit (as defined in the EPA) to the Purchaser.

4. In no event shall Financial Closing be deemed to have occurred unless the Project Company has paid all amounts then due and owing to AEDB under this LOS.

The Project Company shall pay AEDB the processing fee of US $\$ 100,000$ within one (01) month of issuance of this LOS.

The Project Company shall also be responsible for performing and causing any and all other activities necessary and incidental to its obligations under this LOS.

5. The Project Company will have the option (to be exercised in writing only) to terminate this LOS and all (and only all) of the Project Agreements executed by the counterparties thereto at any time before the Required Financial Closing Date. Such termination option may only be exercised upon payment by the Project Company to AEDB of an amount ("Termination Amount") equal to (i) the maximum amount in which the Performance Guarantee can be encashed multiplied by the number of months from the date of issuance of this LOS to the date of receipt by AEDB of the Termination Amount (rounded up to the next whole number) divided by the total number of months from the date of issuance of the LOS to the Required Financial Closing Date, and (ii) the receipt by AEDB in full of the processing fee. In the event of termination of this LOS and/or the Project Agreements by the Project Company without payment of the Termination Amount, AEDB shall be entitled to encash the Performance Guarantee. For the avoidance of any doubt, in the event that the Project Company exercises the termination option during the additional period provided for achieving Financial Closing, the entire doubled amount of the Performance Guarantee shall be encashable on call by AEDB and the "Termination Amount" shall be construed accordingly.

\section{PROJECT COMPANY}

The rights and obligations of the Project Company hereunder shall be performed by the Project Company, provided always that the Main Sponsor (as defined in paragraph D) shall remain primarily responsible for all acts and omissions of the Project Company. 


\section{EQUITY CONTRIBUTION}

[Messrs/Mr] (the "Main Sponsor") will be required to hold at least twenty (20) percent of the equity (being the issued and subscribed share capital from time to time) in the Project Company during the "lock-in period" which will be from the date this LOS becomes effective until the sixth (6th) anniversary of the Commercial Operations Date (as defined in the EPA). The Initial Shareholders (as defined in the IA) shall together hold not less than fifty-one (51) percent of the equity (being the issued and subscribed share capital from time to time) in the Project Company from the date this LOS becomes effective until the sixth (6th) anniversary of the Commercial Operations Date (as defined in the EPA).

\section{E. TERMINATION OF THE LETTER OF SUPPORT}

This LOS will automatically terminate, without notice on the earlier of (i) Financial Closing, and (ii) the date which is seven (7) days after: (a) the Required Financial Closing Date or (b) the Extended Required Financial Closing Date, unless terminated earlier as provided herein above or unless extended in writing by AEDB in accordance with the terms hereof. Neither of the Main Sponsor, the Initial Shareholders or the Project Company shall have any claim against AEDB, the GOP, the GOS or any of their components, organizations, institutions, agencies or instrumentalities on any ground(s) whatsoever arising from the expiration or termination of this LOS as aforesaid. In the event of termination of this LOS for failure of the Project Company to achieve Financial Closing by: (a) the Required Financial Closing Date; or (b) the Extended Required Financial Closing Date, each of the Project Agreements will automatically terminate.

\section{G. GENERAL}

1. The Project Company shall be responsible for the performance of its obligations hereunder jointly and severally with the Main Sponsor.

2. Any notice or communication by or to the Project Company under this LOS shall be deemed a notice or communication to or by the Main Sponsor and the Initial Shareholders.

3. The Project Company represents and warrants to AEDB that it is duly authorized to accept, agree, enter into, deliver and perform this LOS in accordance with its terms on behalf of itself, the Main Sponsor and the Initial Shareholders.

4. This LOS shall be governed by and construed in accordance with the laws of Pakistan and the Courts of Pakistan at Islamabad shall have exclusive jurisdiction in relation to any dispute or matter arising out of or in connection herewith.

5. This LOS shall become effective on the later to occur of (i) submission of the Performance Guarantee, or (ii) the date on which a copy of this LOS signed by the Project Company is received by AEDB.

6. This LOS and the rights and obligations hereunder of the Project Company, the Main Sponsor and the Initial Shareholders shall not be assigned, transferred, sold, mortgaged or encumbered without the prior consent in writing of AEDB.

7. Capitalized terms shall bear the meanings ascribed to them in the pertinent paragraphs herein.

Kindly sign the attached copy of this LOS at the place indicated and return the same to us.

With regards,

Yours sincerely,

[insert name]

[insert designation] 
Alternative Energy Development Board

Received, Agreed and Accepted by

Name

Title:

Main Sponsor Being duly authorised for and on behalf of all Sponsors/the Project Company, the Main Sponsor and the Initial Shareholders

On [Insert Date]

Cc:

1. The Secretary, Ministry of Water \& Power, Islamabad.

2. The Secretary, Energy Department, Government of Punjab, Lahore.

3. Managing Director, National Transmission \& Despatch Company, Lahore.

4. General Manager, CPPA, Lahore

5. The Chief Executive Officer, [ DISCO] 


\section{Annex 5}

The First Schedule to the 2001 Ordinance provides the following tax rates for Individuals and Association of Persons:

(1) Subject to clause (1A), the rates of tax imposed on the taxable income of every individual and Association of Persons except a salaried taxpayer shall be as set out in the following table, namely:-

\section{TABLE}

\begin{tabular}{|l|l|l|}
\hline S. No. & Taxable income & Rate of tax \\
\hline$(1)$ & (2) & $(3)$ \\
\hline 1 & 1. Where the taxable income does not exceed Rs.400,000 & $0 \%$ \\
\hline 2 & $\begin{array}{l}\text { 2. Where the taxable income exceeds Rs.400,000 but does not exceed } \\
\text { Rs.500,000 }\end{array}$ & $7 \%$ of the amount exceeding Rs.400,000 \\
\hline 3 & $\begin{array}{l}\text { 3. Where the taxable income exceeds Rs.500,000 but does not exceed } \\
\text { Rs.750,000 }\end{array}$ & $\begin{array}{l}\text { Rs.7,000 + 10\% of the amount exceeding } \\
\text { Rs.500,000 }\end{array}$ \\
\hline 4 & $\begin{array}{l}\text { 4. Where the taxable income exceeds Rs.750,000 but does not exceed } \\
\text { Rs.1,500,000 }\end{array}$ & $\begin{array}{l}\text { Rs.32,000 + 15\% of the amount exceeding } \\
\text { Rs.750,000 }\end{array}$ \\
\hline 5 & $\begin{array}{l}5 . \text { Where the taxable income exceeds Rs.1,500,000 but does not exceed } \\
\text { Rs.2,500,000 }\end{array}$ & $\begin{array}{l}\text { Rs.144,500 + 20\% of the amount exceeding } \\
\text { Rs.1,500,000 }\end{array}$ \\
\hline 6 & $\begin{array}{l}\text { G. Where the taxable income exceeds Rs.2,500,000 but does not exceed } \\
\text { Rs.4,000,000 }\end{array}$ & $\begin{array}{l}\text { Rs.344,500 + 25\% of the amount exceeding } \\
\text { Rs.2,500,000 }\end{array}$ \\
\hline 7 & $\begin{array}{l}\text { 7. Where the taxable income exceeds Rs.4,000,000 but does not exceed } \\
\text { Rs.6,000,000 }\end{array}$ & $\begin{array}{l}\text { Rs.719,500 + 30\% of the amount exceeding } \\
\text { Rs.4,000,000 }\end{array}$ \\
\hline 8 & $\begin{array}{l}\text { 8. Where the taxable income exceeds Rs.6,000,000 } \\
\text { Rs.1,319,500 + 35\% of the amount exceeding } \\
\text { Rs.6,000,000 }\end{array}$ \\
\hline
\end{tabular}

Provided that in the case of an association of persons that is a professional firm prohibited from incorporating by any law or the rules of the body regulating their profession, the $35 \%$ rate of tax mentioned against serial number 8 of the table shall be $32 \%$ for tax year 2016 and onwards.

(1A) Where the income of an individual chargeable under the head "salary" exceeds fifty per cent of his taxable income, the rates of tax to be applied shall be as set out in the following table namely: 
TABLE

\begin{tabular}{|c|c|c|}
\hline S. No. & Taxable income & Rate of tax \\
\hline (1) & (2) & (3) \\
\hline 1. & Where the taxable income does not exceed Rs.400,000 & ०\% \\
\hline 2. & $\begin{array}{l}\text { Where the taxable income exceeds Rs.400,000 but does not exceed } \\
\text { Rs.500,000 }\end{array}$ & $2 \%$ of the amount exceeding Rs.400,000 \\
\hline 3. & $\begin{array}{l}\text { Where the taxable income exceeds Rs.500,000 but does not exceed } \\
\text { Rs.750,000 }\end{array}$ & $\begin{array}{l}\text { Rs. } 2,000+5 \% \text { of the amount exceeding } \\
\text { Rs. } 500,000\end{array}$ \\
\hline 4. & $\begin{array}{l}\text { Where the taxable income exceeds Rs. } 750,000 \text { but does not exceed } \\
\text { Rs.1,400,000 }\end{array}$ & $\begin{array}{l}\text { Rs. } 14,500+10 \% \text { of the amount exceeding } \\
\text { Rs. } 750,000\end{array}$ \\
\hline 5. & $\begin{array}{l}\text { Where the taxable income exceeds Rs.1,400,000 but does not exceed } \\
\text { Rs.1,500,000 }\end{array}$ & $\begin{array}{l}\text { Rs. } 79,500+12.5 \% \text { of the amount exceeding } \\
\text { Rs. } 1,400,000\end{array}$ \\
\hline 6. & $\begin{array}{l}\text { Where the taxable income exceeds Rs.1,500,000 but does not exceed } \\
\text { Rs.1,800,000 }\end{array}$ & $\begin{array}{l}\text { Rs. } 92,000+15 \% \text { of the amount exceeding } \\
\text { Rs.1,500,000 }\end{array}$ \\
\hline 7. & $\begin{array}{l}\text { Where the taxable income exceeds Rs.1,800,000 but does not exceed } \\
\text { Rs.2,500,000 }\end{array}$ & $\begin{array}{l}\text { Rs.137,000 }+17.5 \% \text { of the amount exceeding } \\
\text { Rs.1,800,000 }\end{array}$ \\
\hline 8. & $\begin{array}{l}\text { Where the taxable income exceeds Rs.2,500,000 but does not exceed } \\
\text { Rs.3,000,000 }\end{array}$ & $\begin{array}{l}\text { Rs. } 259,500+20 \% \text { of the amount exceeding } \\
\text { Rs.2,500,000 }\end{array}$ \\
\hline 9 . & $\begin{array}{l}\text { Where the taxable income exceeds Rs.3,000,000 but does not exceed } \\
\text { Rs.3,500,000 }\end{array}$ & $\begin{array}{l}\text { Rs. } 359,500+22.5 \% \text { of the amount exceeding } \\
\text { Rs.3,000,000 }\end{array}$ \\
\hline 10. & $\begin{array}{l}\text { Where the taxable income exceeds Rs.3,500,000 but does not exceed } \\
\text { Rs.4,000,000 }\end{array}$ & $\begin{array}{l}\text { Rs. } 472,000+25 \% \text { of the amount exceeding } \\
\text { Rs. } 3,500,000\end{array}$ \\
\hline 11. & $\begin{array}{l}\text { Where the taxable income exceeds Rs.4,000,000 but does not exceed } \\
\text { Rs.7,000,000 }\end{array}$ & $\begin{array}{l}\text { Rs. } 597,000+27.5 \% \text { of the amount exceeding } \\
\text { Rs. } 4,000,000\end{array}$ \\
\hline 12. & Where the taxable income exceeds Rs.7,000,000 & $\begin{array}{l}\text { Rs. } 1,422,000+30 \% \text { of the amount exceeding } \\
\text { Rs. } 7,000,000\end{array}$ \\
\hline
\end{tabular}




\section{Annex 6}

\section{Environmental and Social considerations for renewable energy projects and financing}

The development of all solar and wind projects will have both environmental and social implications with the scale and nature of impacts dependent on a number of factors including, among others, plant size, location, nearest settlements and proximity to environmental designations. Some of the key factors are discussed further in the following sections.

\section{APPLICABLE STANDARDS}

In order to deliver a project acceptable to international lending institutions (i.e. to enable finance to be provided), work should be carried out in accordance with the requirements of the key standards and principles set out in the following sections.

\section{EQUATOR PRINCIPLES}

The Equator Principles (EPs) (www.equator-principles.com) consists of ten principles relating to environmental and social assessment and management. In addition, they include reporting and monitoring requirements for Equator Principles Financial Institutions (EPFIs). The EPs set a financial industry benchmark, adopted by financial institutions, for determining, assessing and managing environmental and social risk in projects.

There are currently 78 EPFIs in 34 countries that have officially adopted the EP standards. The institutions listed will not provide finance to clients who do not, or are unable to, comply with the EPs. Some of these lenders such as the European Bank for Reconstruction and Development (EBRD) or other international or local financial institutions may have additional standards to be adhered to.

The EPs apply globally and to all industry sectors and hence are relevant to the solar and wind industries.

The ten EPs relate to the following topics:

- EP1 - Review and Categorization.

- EP2 - Environment and Social Assessment.

- EP3 - Applicable Environmental and Social Standards.

- EP4 - Environmental and Social Management System and Equator Principles Action Plan.

- EP5 - Stakeholder Engagement.

- EP6 - Grievance mechanism.

- EP7 - Independent Review.

- EP8 - Covenants.

- EP9 - Independent Monitoring and Reporting.

- EP10 - Reporting and Transparency.

\section{IFC PERFORMANCE STANDARDS ON SOCIAL AND ENVIRONMENTAL SUSTAINABILITY}

As set out in EP3, countries not designated as High Income OECD countries should apply the social and environmental sustainability standards laid down by the International Finance Corporation (IFC). These standards have been developed for the IFC's own investment projects but have set an example for private companies and financial institutions worldwide. 
The IFC Performance Standards on Environmental and Social Sustainability (www.ifc.org/performancestandards) relate to the following key topics:

Performance Standard 1: Assessment and Management of Environmental and Social Risks and Impacts.

Performance Standard 2: Labor and Working Conditions.

Performance Standard 3: Resource Efficiency and Pollution Prevention

Performance Standard 4: Community Health, Safety and Security.

Performance Standard 5: Land Acquisition and Involuntary Resettlement.

Performance Standard 6: Biodiversity Conservation and Sustainable Management of Living Natural Resources.

Performance Standard 7: Indigenous Peoples.

Performance Standard 8: Cultural Heritage.

Compliance with the IFC Performance Standards will not only facilitate a socially and environmentally sustainable project but will also facilitate the sourcing of finance for the project. In addition, a set of Guidance Notes, corresponding to the Performance Standards, was developed by IFC to offer helpful guidance on the requirements contained in the Performance Standards, including reference materials, and on good sustainability practices to improve project performance.

In addition to EP1 on impact assessment, where there are multiple projects located within close vicinity, the cumulative nature of impacts must be considered for both wind and solar projects. Please refer to the IFC Good Practice Handbook on Cumulative Impacts Assessment for further information (http://www.ifc.org/sustainabilitypublications).

\section{WORLD BANK GROUP ENVIRONMENTAL HEALTH AND SAFETY (EHS) GUIDELINES}

The World Bank Group EHS Guidelines (www.ifc.org/ehsguidelines) are a set of technical reference documents containing general and industry specific examples of good international industry practice. The General EHS Guidelines contain guidance relating to environmental, health, and safety issues, which are applicable across all industry sectors. The industry sector EHS guidelines contain the performance levels and measures that are generally considered to be achievable in new facilities by existing technology at reasonable costs and are designed to be used together with the General EHS Guidelines document. Specific EHS Guidelines, which are recommended for reference, include the EHS Guideline for Wind Energy and the EHS Guideline on Electric Power, Transmission and Distribution.

\section{LOCAL, NATIONAL AND INTERNATIONAL ENVIRONMENTAL AND SOCIAL LEGISLATION AND REGULATIONS}

Environmental and social legislation and regulations vary between countries and specific regions; however, the EP and IFC Performance Standards set the minimum acceptable standard for developments worldwide.

A large number of countries have national legislative requirements that are on a par with or higher than the EP / IFC standards and guidelines. In this instance, the more stringent national requirements should be reviewed and adhered to.

In countries where environmental and social legislation requirements are less demanding, a project seeking financing by the IFC / EPFI must be developed in accordance with these requirements but must also commit to comply with the EP / IFC standards. 


\section{Annex 7}

\section{NOTIFICATION Dated: $\mathbb{I} \quad-06-2015$}

No.01-32-2015/SO-VI/354/15n exercise of the powers conferred by sub-section(2) of section 10 of the Colonization of Government Lands Act,1912 and in supersession of statement of conditions issued vide notification No. 09-294-03/SO1/306 dated 09-05-2012, the Government of Sindh are pleased to issue the following statement of conditions for grant of state land for the purpose of producing renewable energy through wind mills, Solar technology, Bio-fuels, Hydro power, Waste to Energy (Municipal or agro waste) on lease upto 30 years

1. Statement of conditions is issued subject to the provision of the colonization of Government Land Act, 1912.

2. In this Statement of conditions, unless there is anything repugnant in the subject or context:

a) "Act" means the colonization of Government Lands Act, 1912;

b) "Bio-fuels" means a type of energy derived from botanical plants and animal materials. Examples of bio fuels include ethanol (made from corn, sugarcane or other agri-product), biodiesel (made from vegetable oils and liquid animal fats), green diesel (derived from algae and other plant sources) and biogas (methane derived from animal manure and other digested organic material);

c) "Collector" means the Collector of the District as described in Sindh Land Revenue Act 1967;

d) "Company" means a company registered under companies Ordinance 1984;

e) "Events of Force Majeure" any event or circumstance or a combination of events and circumstances which are beyond the responsible control of the affected party, which such party could not have prevented or responsibly over come with the exercise of responsible skill and care in relation to the implementation of the project which do not result from the negligence of such party or the failure of such party to perform its obligations hereunder and which are of an incapacitating nature and of severe magnitude;

f) "Government" means Government of Sindh;

g) "grant" means lease of land made under these conditions;

h) "Hydro power" means the conversion of the potential energy of the running/ falling water into electrical energy through turbines for producing electrical power;

Page 1 of 5 
i) "Land" means land vesting in Government, authority or autonomous body that may be used for producing renewable energy, but does not include the private (Kabooli) land and land already reserved for any specific purpose unless it is surrendered by the competent authority;

j) "Lease" means lease for a period of thirty years for which land is granted under this statement of conditions;

k) "Market price" means the market price of lease of land prevailing at the time of lease of land determined in accordance with this statement of conditions;

I) "Project" means project sponsored for use of land for producing energy through renewable resources;

m) "Renewable Energy Technology" means, the use of wind mills, Solar technology,Bio-fuels, Hydro power, Waste to Energy (Municipal Waste or Agro Waste) for producing energy;

n) "Solar Power" means the conversion of sunlight into electricity, either directly using photovoltaic's (PV), or indirectly using concentrated solar power (CSP). Concentrated solar power systems use lenses or mirrors Photovoltaic's convert light into electric current by using solar array;

o) "Waste to Energy (Municipal Waste or Agro-waste)" means the process in which the Solid waste (Agricultural waste or municipal waste) is converted into thermal energy to generate electric power;

p) "Wind Mills" means the electric power generating facility comprising of wind power generators (being the machines with generators for conversion of wind energy into electric energy), including without limitation all energy producing equipment and its auxiliary equipment, data: communication and recording equipment and systems, the anemometry system, the complex monitoring system, spare parts together with allied and incidental infrastructure and facilities and all other equipment or facilities necessary for delivery of electricity to any grid;

3. The Government may grant lease, for the development of Renewable Energy Power projects, in accordance with the provisions of the Act to Energy Department, Govt. of Sindh, a company, a person or group of persons, organization at the market price,

provided that; no land shall be granted at the rates less than:

i. Rs. $3000 /$ - per acre per annum for first ten years

ii. Rs. 5000/- per acre per annum for next 10 years

iii. Rs. 8,000/- per acre per annum for further 10 years 
4. No person shall as a right be entitled to the grant of the land under these conditions and Government shall have absolute discretion in selection of grantees.

5. The land granted under these conditions shall be granted for a period not exceeding thirty (30) years. However, the Government may renew the lease for a further period of thirty years before end of initial period.

6. Market price shall be proposed by the collector after taking following into consideration

I) The price of land transferred in the same area for similar use, if any, during the past twelve months

II) The valuation table notified by the Board of Revenue Sindh under the Stamp Act 1899 for the purpose of levy of stamp duty at the time of registration of a sale deed in respect of sale of similar land, and

IiI) Such other modes as deemed fit to provide a fair basis for assessment of such price.

7. Proposed market price shall be considered by a "Scrutiny Committee" comprising of:

a) Senior Member, Board of Revenue, Sindh

b) Secretary, Land Utilization Department, Govt of Sindh

c) Secretary, Energy Department, Govt of Sindh

d) Secretary Finance Department, Govt of Sindh,

e) Commissioner of the concerned Division

f) Collector of the concerned District.

Chairman

Member

Member

Member

Member

Member

8. If the land is granted to Energy Department, Govt. of Sindh, the said department may carryout technical survey and may sub-lease the same to the project developer (SPV) keeping in view the requirement of such project.

9. Application for the grant of Land by a company, a person or group of persons, organization shall be made to the Government of Sindh through Energy Department. Government of Sindh. The Energy Department may forward the application, along with a copy of valid LOI already signed with the applicant with their observation and recommendations, for the allotment of land on lease as per this statement of condition.

10. The Land Utilization Department after considering the observations and recommendations of Energy department may call for the report from concerned Collector regarding the availability of land along with prevailing market price and site plan duly authenticated by the collector. Upon receipt of such report the matter shall be placed before Scrutiny Committee, mentioned in condition No 7 of the statement of conditions 
11. The scrutiny committee, after considering the availability report along with site plan received from the Collector, hearing the applicant and verifying the documents provided by him and considering the observations and recommendations of Energy Department and other factors, shall formulate its recommendations including the rate of market price and submit the same through summary to the Government for approval.

12. After approval of Government and acceptance of offer of lease a Lease Deed will be executed on payment of all the fees or charges including lease money of first 10 years and all codal formalities are completed. The fee or charges for the next 10 years shall be paid 3 months prior to the expiry of previous lease period.

13. Terms and conditions for grant of lease of land shall include the following:-

(a) The grantee shall have exclusive possession and leasehold rights over the leased land for establishment of renewable energy projects for installation, maintenance and operation. This will include repairing, replacing, removing all or any part or element of the power plant.

(b) Grantee shall have'right to construo, install, operate, maintain, repair replace and remove all or any watift or element of the plant.

(c) Government shall not permit any other activity on leased land except the use for production of other renewable energy resources as recommended by the Energy Department, Government of Sindh without harming or obstructing the operation and maintenance of the plant, impeding or decreasing the output or efficiency of the plant. The grantee shall pay the additional development charges as assessed by the Energy Department for multipurpose use of land for production of renewable energy.

(d) The grantee shall be liable to abide by all the intemational design codes and environmental guidelines while designing the renewable energy Projects.

(e) Grantee will be entitled to quite use and enjoyment of the leased land without interference so long as the grantee is not in default under terms of statement of condition.

(f) Government will not engage in any activity that would harm or obstruct the operation and maintenance of the plant, impede or decrease the output or efficiency of plant.

(g) The Grantee will contribute towards improvement in the livelihood of local population within their ear marked area (within the Dehs) in terms of supporting activities and inputs which can enhance quality of their 
livelihood. There shall be definite preference to locals for semi-skilled and unskilled jobs in project area.

(h) The grantee shall submit annual report regarding provision of jobs to eligible local persons to the Energy Department, Government of Sindh

(i) The grantee shall arrange techrical trainings and capacity building of the local candidates in order to enable them to join the renewable energy industry.

(j) Upon recommendation of the Energy Department, Government of Sindh the grantee will be entitled to create security interests on the leased land in favour of its lenders. The government may enter into and execute direct agreement with lenders of the grantee in relation to such security interests.

14. Grantee shall not be entitled to subtlet, transfer, or transfer possession of the leased land without the approval of the Government of Sindh on the recommendätion of the Energy Department.

Land will be granted for specific purpose of establishment of renewable energy projects for energy production. Grantee shall submit project activities, milestones and other project related quarterly reports to Land Utilization Department through Energy Department.

16. The grantee and Government will execute the lease deed, which will contain terms contained in this statement of conditions and such additional terms conditions, which are not inconsistent with the statement of conditions. Lease deed shall be executed and registered at the expenses of grantee after deposit of occupancy value in respect of the leased out land.

The Energy Department will oversee the progress of the project from time to time and furnish quarterly report to the Government through Land Utilization Department.

If the government is satisfied that the lessee or his successor-in-interest, as the case may be, has committed any breach or non-observance of any condition herein before contained or mentioned in the lease deed or the Act or this statement of conditions, the lease may be resumed in favour of the Government under the provisions of the Act.

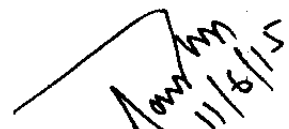

(SAJID JAMAL ABRO)

SECRETARY TO GOVERNMENT OF SINDH LAND UTILIZATION DEPARTMENT

Page 5 of 5 
NO.01-32-2015/SO-VI /354/15 Dated -11-06-2015

\section{A copy is forwarded for information to:-}

1. Principle Secretary to Chief Minister Sindh.

2. The Afember (All), Board of Revenue, Sindh, Karachi.

3. The Secretary Energy, Energy Department Government of Sindh.

4. The Secretary/ Director General, Sindh Board of Investment Karachi.

5. The Commissioners (All) Sindh.

6. The Deputy Commissioners (All) Sindh.

7. The Deputy Secretary (Staff) to Chief Secretary, Sindh Karachi.

8. P.S to Minister Finance and Energy Department Govt. of Sindh.

9. The Section Officer (Staff) to Senior Member, Board of Revenue, Sindh. Karachi.

10. P.S to Member (LU) land Utilization Department Sindh.

11. The Publisher, Sindh Government Printing Press, Karachi, for Publication in the next issue of Govt. Gazette.

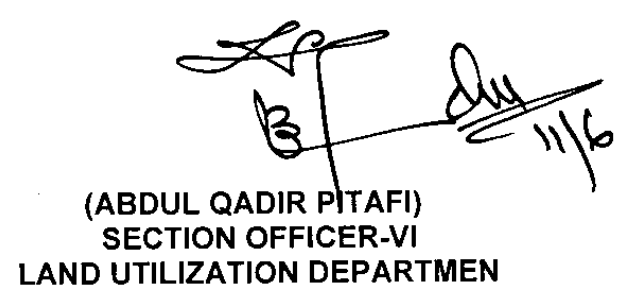

Page 6 of 6 


\section{Annex 8}

Transmission and Distribution Maps

\section{Already Planned Interconnection Schemes For Wind Power Projects at Jhimpir, Gharo and Near Jamshoro (NBT-1 \& 2)}

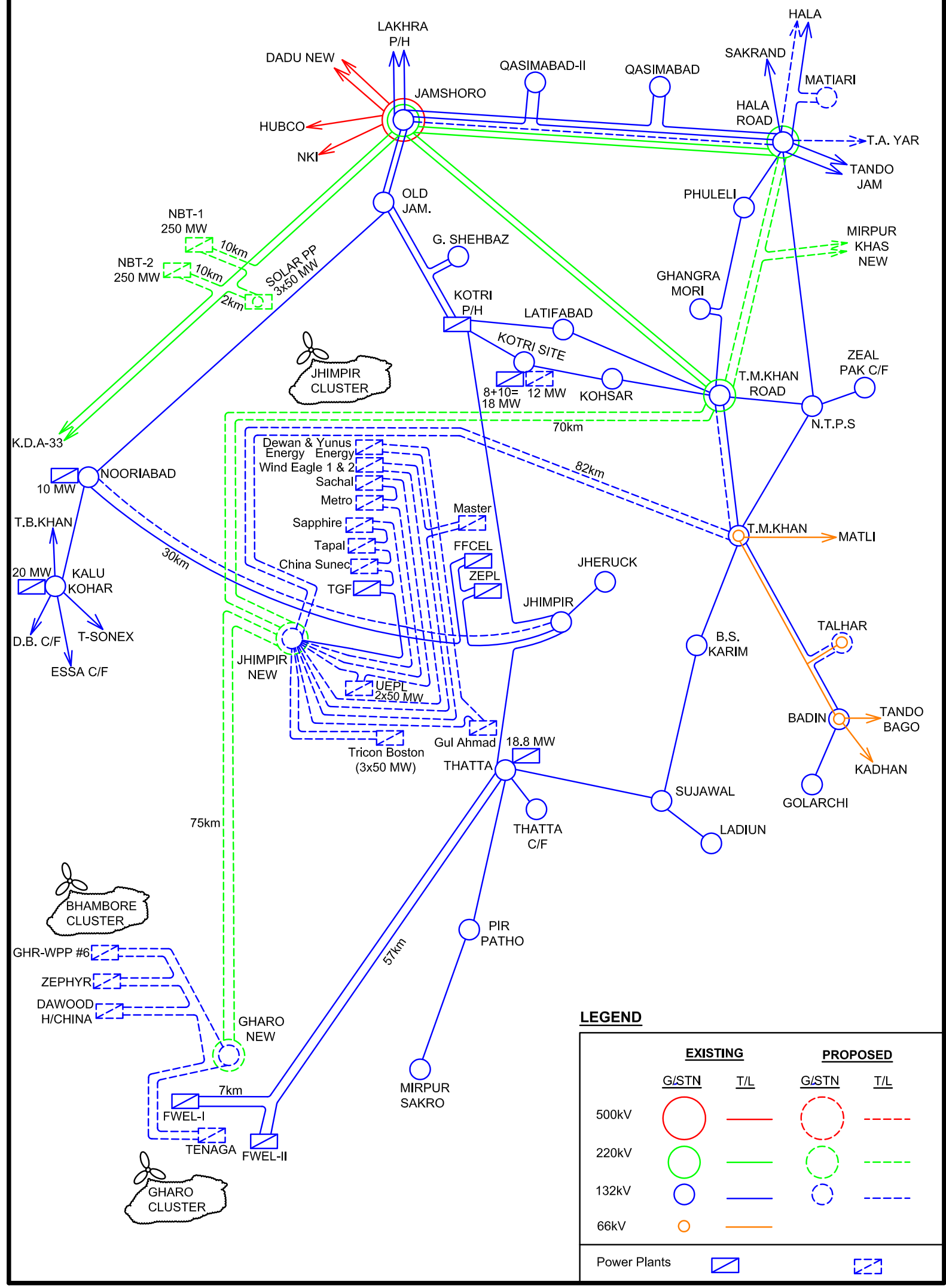




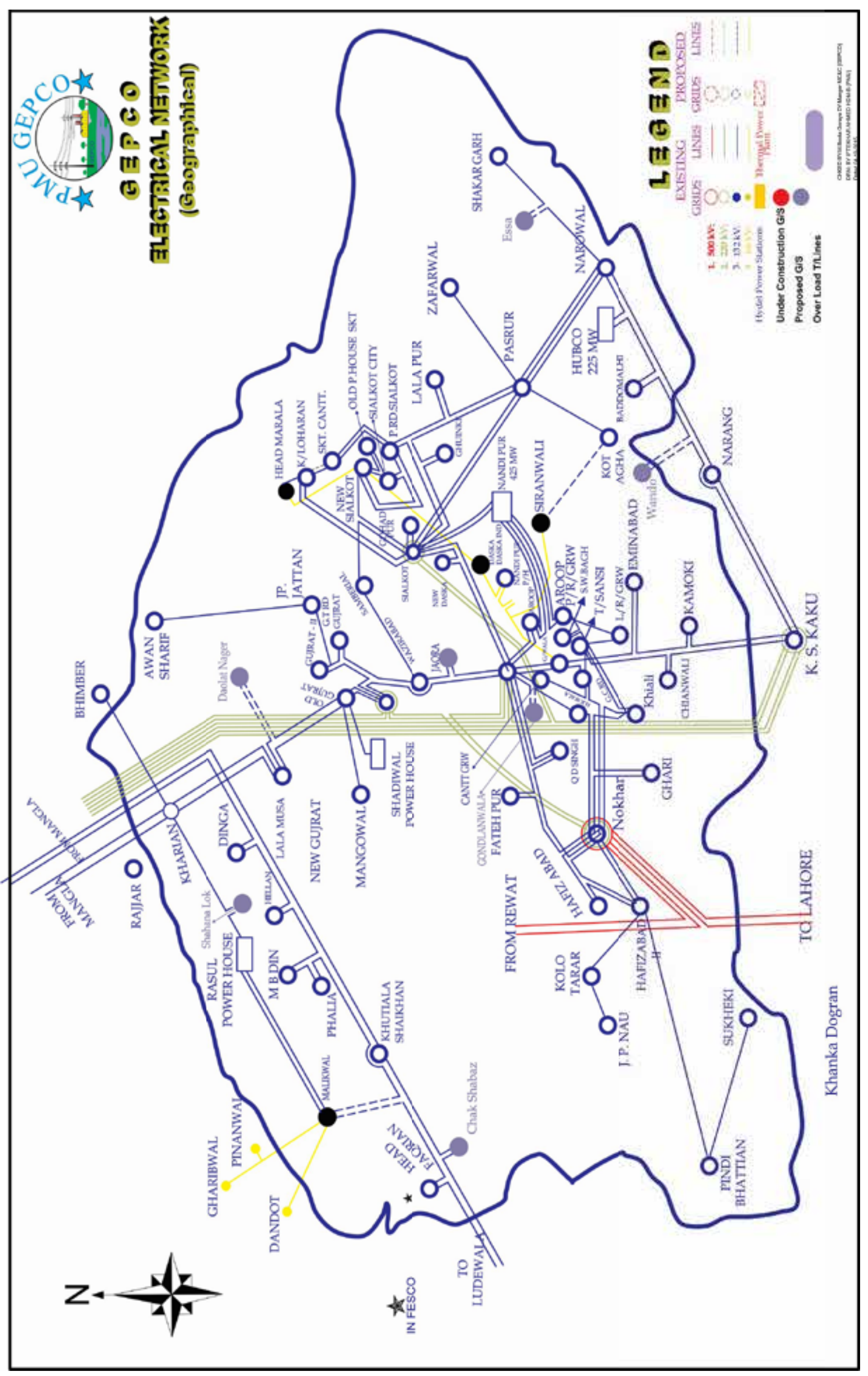




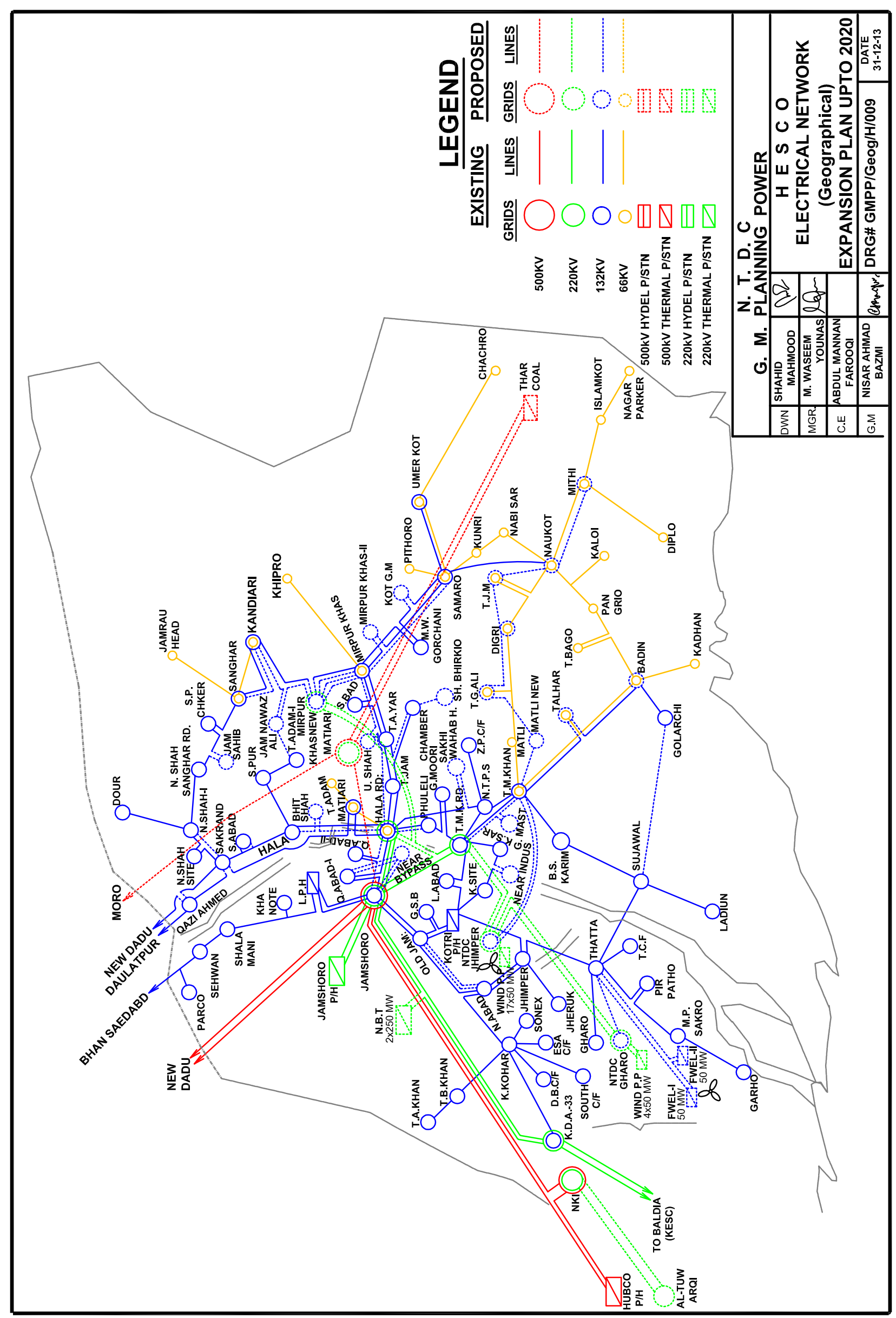




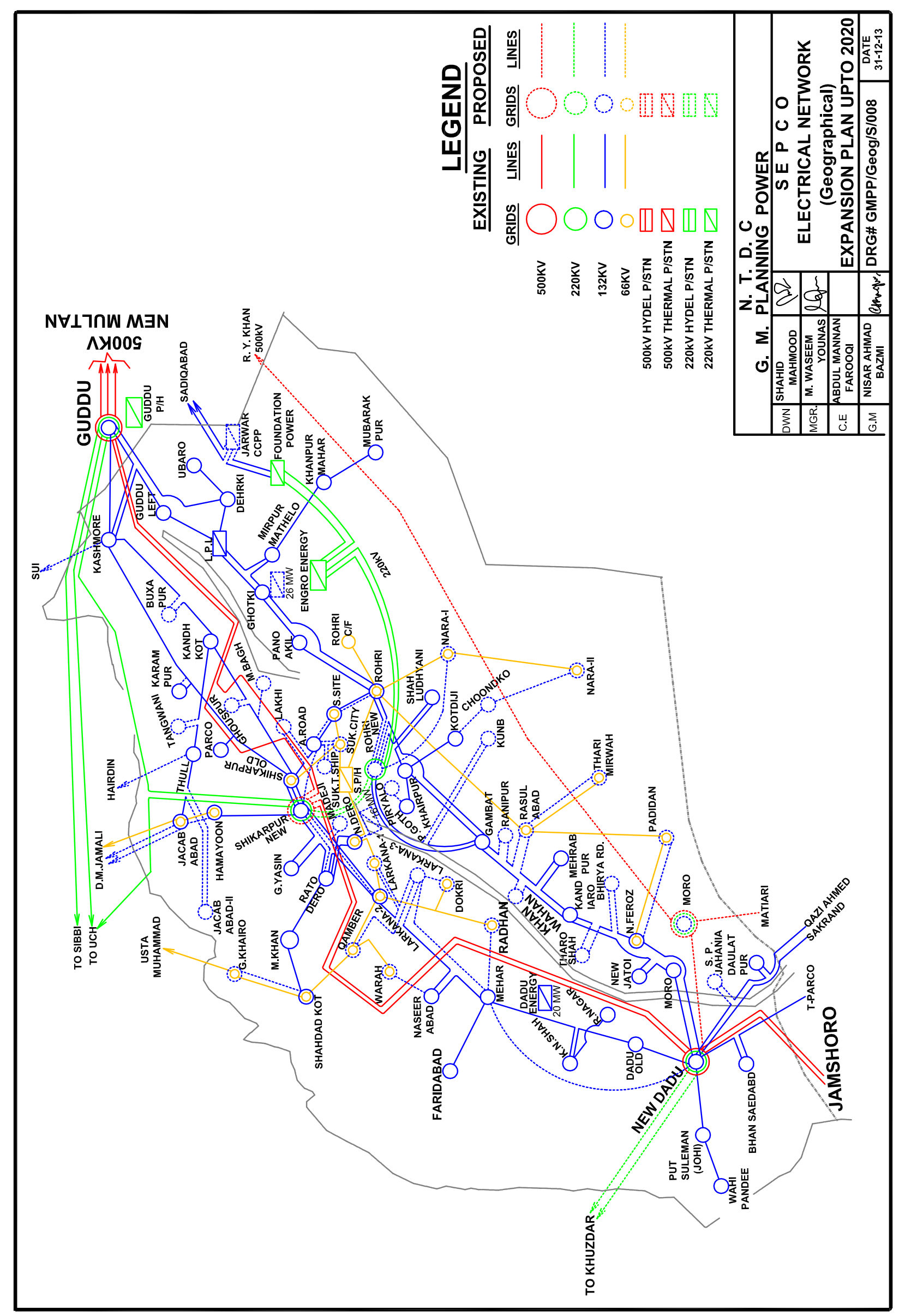




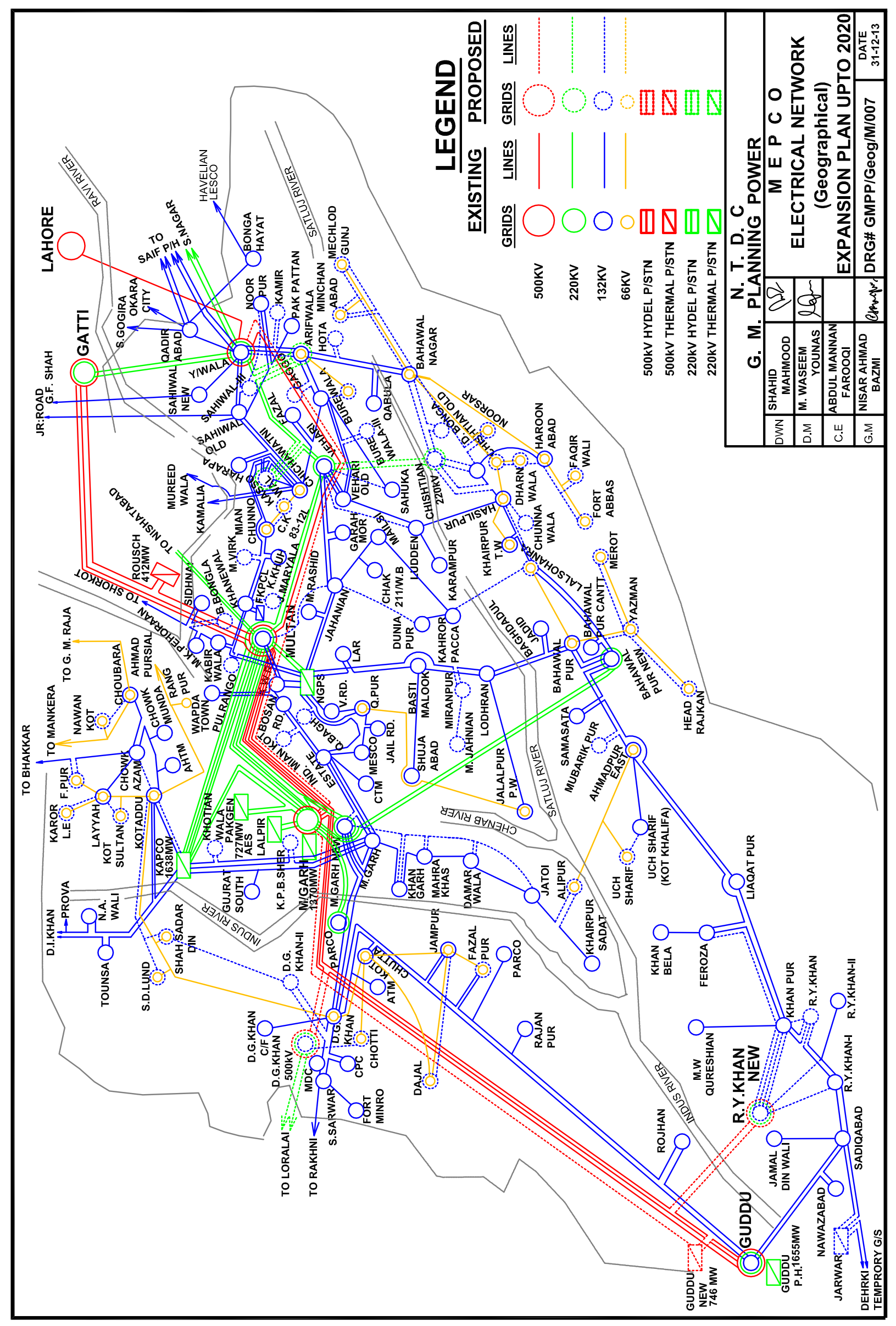




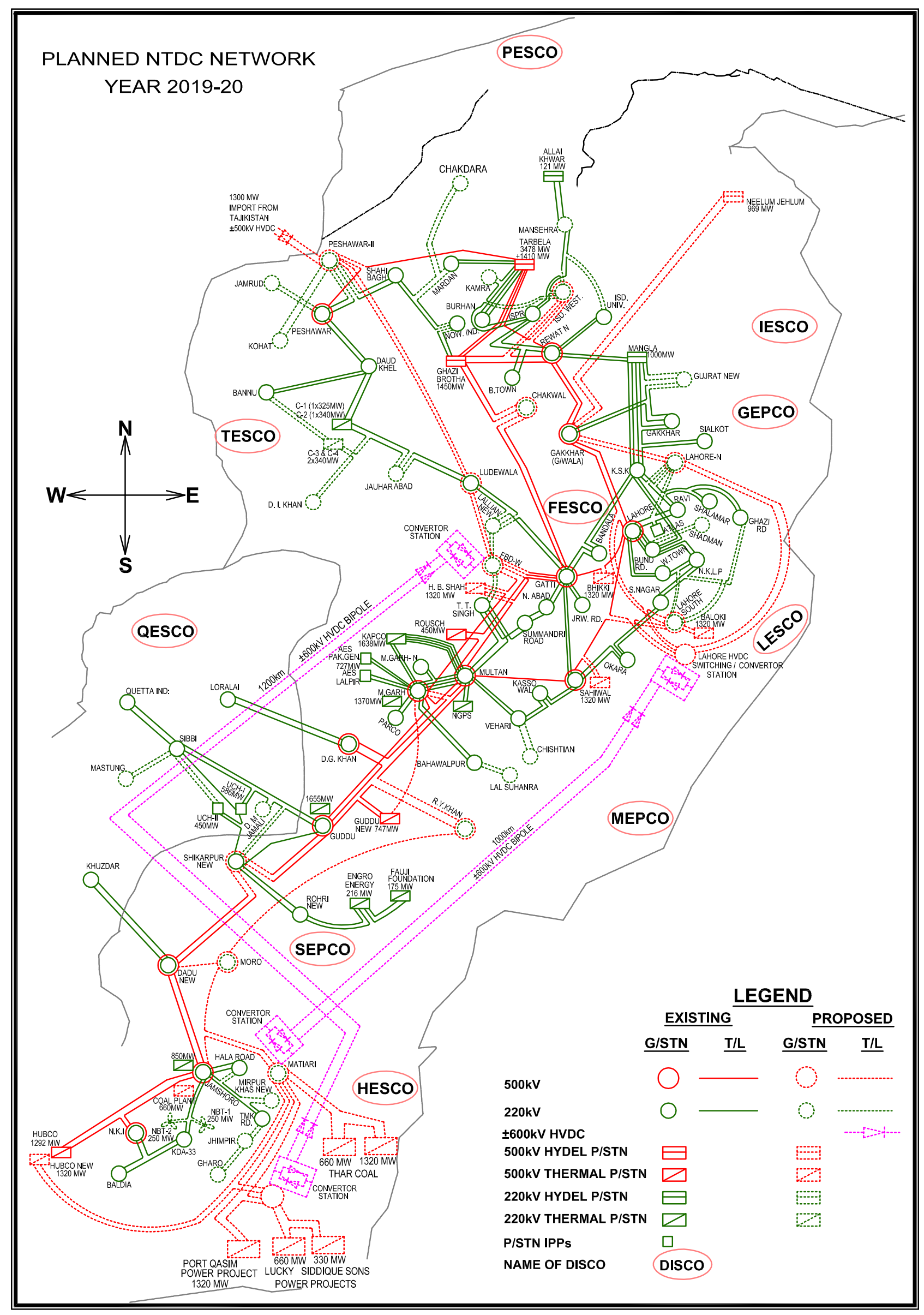



Bryanne Tait

IFC Regional Lead for Energy

and Resource Efficiency Advisory

Middle East and North Africa

Phone: +97143601016

E-mail: btait1@ifc.org 